I N T ER N ATIONAL MONETARY FUND

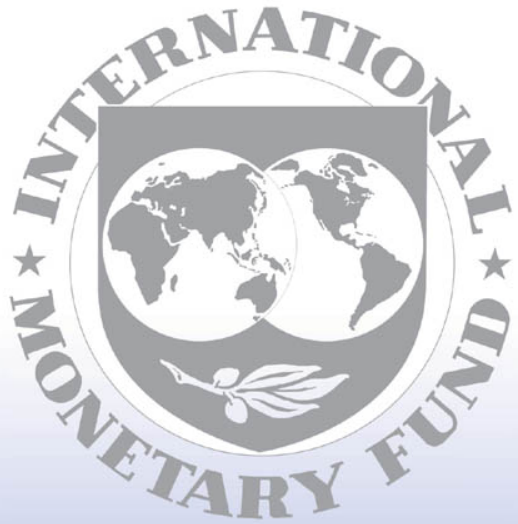

Staff

Country

Reports 


\title{
Republic of Madagascar: Enhanced Initiative for Heavily Indebted Poor Countries Completion Point Document
}

This paper was prepared by staff of the International Monetary Fund and the World Bank in connection with the Executive Board's consideration of the Republic of Madagascar's progress under the Enhanced Initiative for Heavily Indebted Poor Countries. It is based on the information available at the time it was completed on October 4, 2004. The views expressed in this document are those of the staff team and do not necessarily reflect the views of the government of the Republic of Madagascar or the Executive Board of the IMF.

The policy of publication of staff reports and other documents by the IMF allows for the deletion of market-sensitive information.

To assist the IMF in evaluating the publication policy, reader comments are invited and may be sent by e-mail to publicationpolicy@imf.org.

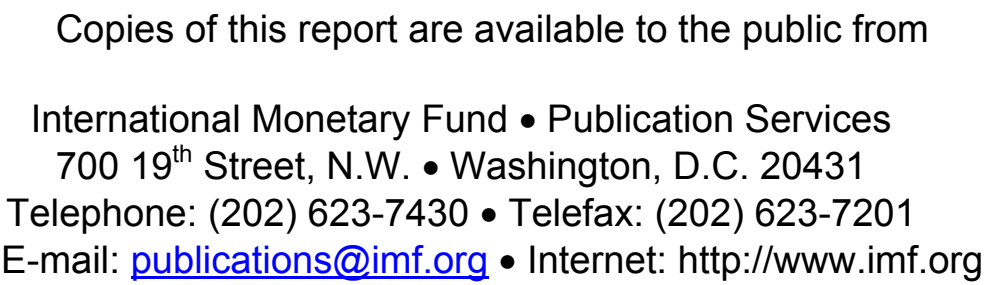

Price: $\$ 15.00$ a copy

\author{
International Monetary Fund \\ Washington, D.C.
}


This page intentionally left blank

CInternational Monetary Fund. Not for Redistribution 


\section{INTERNATIONAL DEVELOPMENT ASSOCIATION \\ AND INTERNATIONAL MONETARY FUND}

REPUBLIC OF MADAGASCAR

\section{Completion Point Document for the Enhanced Heavily Indebted Poor Countries (HIPC) Initiative}

Prepared by the Staffs of the International Development Association and the International Monetary Fund

Approved by Callisto Madavo and Gobind Nankani (IDA) and Thomas Krueger and Mark Plant (IMF)

October 4, 2004

Table of Contents

I. Introduction

II. Assessment of Requirements for Reaching the Completion Point

III. Debt Sustainability Over the Medium Term

A. Data Reconciliation and Revision of Assistance ............................................. $\frac{18}{19}$

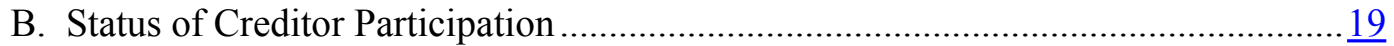

C. Updated Debt Sustainability Analysis............................................................. $\frac{21}{21}$

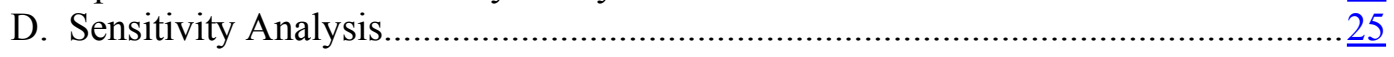

IV. Conclusions .............................................................................................................................. 29

V. Issues for Discussion ....................................................................................................... 


\section{Boxes}

1. Status of Triggers for the Floating Completion Point under the Enhanced HIPC Initiative.

2. Madagascar: Breakdown of the Increase of the NPV of Debt-to-Exports Ratio as of end-003.

3. Assumptions Used in the Debt Sustainability Analysis.

Figures

1. External Debt and Debt-Service Indicators for Medium and Long-Term Public Sector Debt, 2003-23

2. Sensitivity Analysis

Text Tables

1. Use of HIPC Funds Against the Criteria Set at the Decision Point....................... $\underline{8}$

2. Social Expenditure Before and After Interim Assistance.................................. 10

3. Distribution of Primary Teachers across Zones..................................................... $\frac{15}{31}$

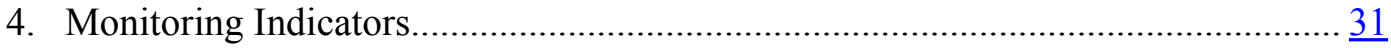

Tables

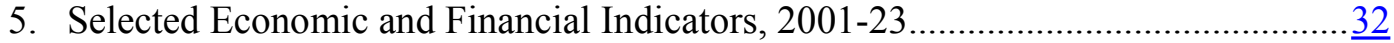

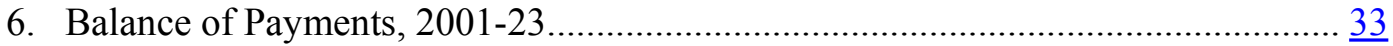

7. Nominal and Net Present Value of External Debt Outstanding as of

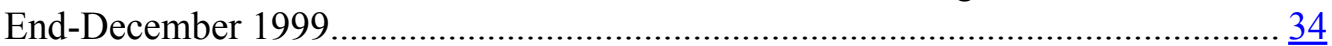

8. Estimated Assistance at Decision Point (Amended)......................................... $\underline{35}$

9. Comparison of Discount and Exchange Rate Assumptions at End-1999

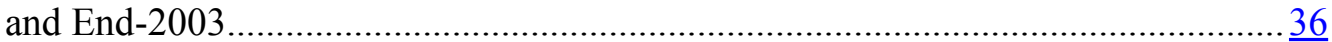

10. External Public and Publicly Guaranteed Debt at End-December 2003................. $\frac{37}{37}$

11. Comparison of Net Present Value of External Public Debt Between Decision Point and Completion Point

12. Net Present Value of External Debt, 2003-23 ....................................................... 39

13. External Debt Service After Full Implementation of Debt-Relief Mechanisms, 2003-24

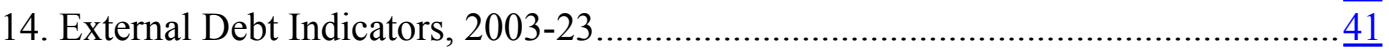

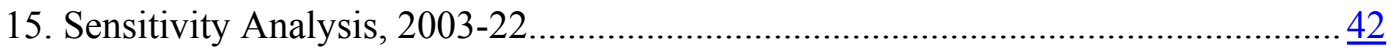

16. Status of Creditor Participation under Enhanced HIPC Initiative............................. $\frac{43}{44}$

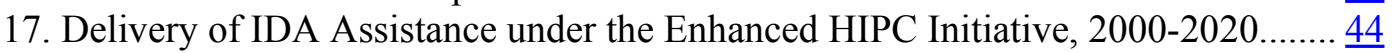

18. Delivery of IMF Assistance under the HIPC Initiative ..................................... 45

19. HIPC Initiative: Status of Country Cases Considered under the Initiative, end-Sept 2004

20. Paris Club Creditors' Delivery of Debt Relief Under Bilateral Initiatives Beyond the HIPC Initiative.

Appendix

I. Debt Management 


\section{Summary and Conclusions}

- The staff of the IMF and IDA consider that Madagascar has met the conditions for reaching the completion point under the enhanced Heavily Indebted Poor Countries (HIPC) Initiative as specified in the decision point document. Madagascar's macroeconomic program is on track, as evidenced by broadly satisfactory performance under the Poverty Reduction and Growth Facility (PRGF) arrangement. The Government has made significant progress in implementing the structural and social programs despite delays due to the political crisis in 2002. The Joint Staff Assessment (JSA) of the first annual Poverty Reduction Strategy Paper (PRSP) progress report, which was prepared in broad consultation with civil society and the donor community, considers that important progress has been made in the implementation of the PRSP. Efforts undertaken during the first year of the PRSP implementation provide evidence of the Government's continued commitment to poverty reduction.

- The interim relief provided under the enhanced HIPC Initiative has allowed the Government to increase social spending in the recent past. Budgetary savings from interim debt service relief have been used in accordance with the criteria set forth by the authorities at the decision point with social sectors, governance, and infrastructure featuring prominently. Despite slow progress in implementing the poverty-reducing expenditure tracking mechanisms, further improvement is expected to take place by the end of 2004 with the reforms supported under the Poverty Reduction Support Credit (PRSC).

- Financing assurances on the provision of assistance under the enhanced HIPC Initiative have been obtained from creditors representing about 90 percent of total debt relief in net present value terms (NPV). The authorities have contacted non-Paris Club and commercial creditors for obtaining HIPC debt relief. Some non-Paris Club creditors have provided partial relief.

- Debt Sustainability Analysis (DSA). Based on the debt reconciliation exercise for the completion point, the end-1999 stock of debt in NPV terms has been revised upward by US\$22 million. The full delivery of HIPC assistance together with additional bilateral assistance will reduce the NPV of debt-to-exports ratio at completion point significantly below the HIPC threshold to 137 percent. As such, Madagascar does not qualify for topping-up. The DSA suggests that with sound macroeconomic policies, supporting structural reforms and in the absence of exogenous shocks, this ratio will trend down during the complete period of analysis. Sound policies are critical as the sensitivity analysis suggests that Madagascar is particularly vulnerable to exogenous shocks such as a decline in the terms of trade and other shocks which could lower GDP growth.

- The staffs of the IMF and IDA recommend that their respective Executive Directors determine that Madagascar has reached the completion point under the enhanced HIPC Initiative. 


\section{INTRODUCTION}

1. This paper discusses Madagascar's progress under the HIPC Initiative and seeks Board approvals of its completion point. In December 2000, the Executive Boards of the International Monetary Fund (IMF) and the International Development Association (IDA) agreed that Madagascar had met the requirements to reach its decision point under the HIPC Initiative and defined a set of conditions for Madagascar to reach the completion point. ${ }^{1}$

2. Total assistance to be provided to Madagascar under the HIPC Initiative amounts to US\$836 million in NPV terms, US\$22 million higher than the decision point estimate (US\$814 million). This represents a reduction of 40.2 percent of the revised NPV of debt at end-1999 after assuming full use of traditional debt relief mechanisms. Based on the new common reduction factor, IDA and the IMF will have to provide debt relief in NPV terms, in the amount of US\$256 million and US\$19 million, respectively. Both institutions have been providing interim debt relief since the decision point. Madagascar also benefited from interim assistance provided by the African Development Bank (AfDB), the European Union (EU), the OPEC Fund (OPEC) as well as from Paris Club creditors. The total amount of interim assistance extended to Madagascar by these creditors through December 2003 amounted to approximately US\$256 million, of which US\$47 million and US\$7 million were provided by IDA and the IMF, respectively.

3. This paper is organized as follows. Section II assesses Madagascar's performance in meeting the requirements for reaching the completion point, as set out in the decision point document. Section III reviews the status of creditor participation and the delivery of debt relief to Madagascar under the enhanced HIPC Initiative, and presents the results of the updated DSA. Sections IV and V present the conclusions and issues for discussion respectively.

\section{AsSessment of ReQuirements for Reaching the CoMPletion Point}

4. In the view of the staffs of IDA and the IMF, Madagascar satisfied almost all completion point conditions set out at the decision point in Box 8 of the decision point document. At that time, the Boards agreed that Madagascar would reach the floating completion point on the basis of (i) the preparation of a full PRSP and its satisfactory implementation for at least one year; (ii) maintenance of macroeconomic stability through satisfactory implementation of the IMF-supported program; (iii) use of budgetary savings from HIPC interim relief in accordance with the criteria laid out at the decision point; and (iv) satisfactory implementation of policy reforms for improving governance and service delivery to the poor.

\footnotetext{
${ }^{1}$ See "Madagascar-Enhanced Heavily Indebted Countries Initiative - Decision Point Document" (www.imf.org), and IDA/R2000-229, (12/5/00).
} 


\section{A. Poverty Reduction Strategy Paper (PRSP)}

5. Madagascar prepared a fully participatory PRSP in July 2003. Its preparation took longer than originally expected due to the political crisis in the country which paralyzed political and economic life during most of 2002. The PRSP and the JSA of the strategy were presented to the Boards of IDA and the IMF in November 2003.

6. The Government has released the First Annual Progress Report on the implementation of the PRSP covering the period July 2003-June 2004. The Progress Report, which reflects the progress made on poverty reduction and on the policy front, was prepared by the Government through a participatory process. The Progress Report and its accompanying JSA will be considered by the Boards of IDA and the IMF along with the present document. The JSA considers that important progress has been made in the implementation of the PRSP.

\section{B. Macroeconomic Performance in 2001-04}

\section{The $\mathbf{2 0 0 2}$ political crisis and repeated fiscal slippages made for uneven} progress under the PRGF arrangement, but overall performance has been broadly satisfactory. ${ }^{2}$ The Board of the IMF is expected to complete the fifth review under the current PRGF arrangement concurrently with this document. In concluding the second review under the PRGF on December 23, 2002 (IMF Country Report No. 03/6), the Board also extended the PRGF arrangement, which was originally scheduled to expire at end-February 2004, to end-November 2004 in order to accommodate a new test date in place of that missed in 2002 because of the political crisis. The Board further extended the PRGF arrangement to March 1, 2005, in concluding the fourth review on March 17, 2004, owing to fiscal slippages that emerged in the second half of 2003. As a consequence of these developments, the completion point under the enhanced HIPC Initiative was delayed.

\section{Macroeconomic performance over the period 2001-03 was significantly} affected by the political strife in 2002. Real GDP growth was 6 percent in 2001, but declined by about 13 percent in 2002, due to a major political crisis that brought economic activity to a near standstill for the first six months of the year. Rebounding from the 2002 economic downturn, real GDP grew by 9.8 percent in 2003. Inflation rose to 13.9 percent in 2002 (on a year-on-year basis), before receding to -0.8 percent in 2003 .

\footnotetext{
${ }^{2}$ Madagascar's recent, albeit mixed, progress in macroeconomic performance and structural reforms, follows a long period of weak performance in the early nineties, characterized by weak GDP growth, very high inflation rates and deteriorating fiscal deficits. While Madagascar's economy had begun to show improvements towards the end of the nineties due to the implementation of a reform program accompanied by liberalization and structural measures, debt levels had started to build up. At the time of the decision point in 2000 the NPV of debt to exports and to GDP (after traditional relief) were close to 250 percent and 55 percent, respectively. See Madagascar - Enhanced Heavily Indebted Poor Countries Initiative - Decision Point Document (www.imf.org), and IDA/R2000-229, (12/5/00) mentioned above.
} 
The external current account deficit (including official grants), declined from 5.6 percent of GDP in 2000 to 1.3 percent in 2001, reflecting a strong export performance, notably in the export processing zones (EPZ) and the vanilla sector. Subsequently the current account deficit increased to 6 percent of GDP, due to a sharp decline in EPZ activities and current transfers, following the 2002 political crisis.

\section{Recent economic developments were marked by a sharp depreciation of the} Malagasy franc and two cyclones that hit the country in early 2004. The exchange rate depreciated by about 50 percent against the Euro in the first half of 2004, owing to (i) strong imports due to higher petroleum prices, increased government capital expenditures, and an acceleration of private imports in response to tax and tariff exemptions granted for imports of capital goods and selected other items in September 2003; and (ii) weak exports, as a result of two cyclones that damaged the vanilla and shellfish industries. The exchange rate stabilized during the third quarter of 2004, as import demand weakened and the Government implemented important adjustment measures.

10. Performance on the fiscal front was mixed during the period 2001-03. In 2001, tax revenue fell substantially short of the program target, due to weaknesses in customs administration and some exceptional exemptions granted in the run-up to the December 2001 presidential elections. Despite this revenue performance, the overall deficit, on a commitment basis and excluding grants, was contained at 8.1 percent of GDP against a revised program target of 9.9 percent, as government expenditures were lower than programmed. As a result of the decline in domestic activities, tax revenue fell further to 7.7 percent of GDP, but due to lower expenditures, the overall deficit was contained at 7.7 percent of GDP, compared with 9.7 percent envisaged under the original program. Fiscal slippages occurred in the second half of 2003, owing mainly to the impact of tax and tariff exemptions mentioned above. The deficit on a commitment basis, excluding grants, amounted to 9.3 percent of GDP in 2003, compared with 7.6 percent expected under the program. This was mainly due to higher expenditures, including on priority sectors.

\section{In 2004, the Malagasy authorities have started to address outstanding} weaknesses of the tax system, including through measures aimed at lowering tariff barriers, broadening the revenue base, and simplifying the tax system. Moreover, the tax exemptions granted in 2003 for non-capital goods were removed in July 2004. The authorities have also taken measures aimed at strengthening tax administration, including (i) introduction of anticorruption measures in the tax and customs departments;

(ii) tightening of conditions for importers that benefit from a customs duties advance scheme; (iii) acceleration of customs clearance procedures; (iv) rotation of 25 percent of customs agents; (v) establishment of performance contracts for customs agents; and (vi) installation of the most recent ASYCUDA software by UNCTAD. In addition, the tax department has reinforced its tax recovery efforts, mainly through the acceleration of the recovery of tax arrears and more systematic information sharing with the public procurement office. The implementation of these measures should help ensure that the tax revenue-to-GDP ratio for 2004, set at 11.2 percent, can be met. 
12. Madagascar made progress, albeit slowly, in implementing the envisaged structural reforms in the areas of budgetary management, tax administration, and privatization during 2001 to 2004. In particular: (i) improvements have been made in public financial management towards better controls and transparency; and (ii) the private sector environment has been made more business friendly through reforms of the investment code and the regulatory framework, although privatizations proceeded more slowly than expected. Furthermore, Madagascar has liberalized and simplified its external trade regime.

13. Performance under the PRGF arrangement through end-June 2004 has been broadly satisfactory, taking into account the impact of adverse exogenous shocks and corrective measures taken by the authorities. While several performance criteria for end-March and indicative targets for end-June 2004 have been missed, deviations were generally small and mainly related to the impact of two major cyclones. For the rest of 2004, Madagascar is expected to maintain prudent financial management, as well as to focus on capacity building of institutions that are needed to sustain a growing market economy and ensure an equitable distribution of the opportunities and resources brought about by economic expansion.

\section{Use of HIPC Interim Relief and Tracking of Poverty Reducing Spending}

14. Budgetary savings from interim debt service relief have been used broadly in line with the criteria set forth at the decision point (Table 1). ${ }^{3}$ HIPC savings were used mainly to support improved service delivery in primary education, health and rural infrastructure (roads and water). The shares allocated to education and health were higher than expected, increasing from 41 percent in 2001 to 63.5 percent in $2004 .^{4}$ The justice sector received less than originally intended, though this was compensated for by increases in the government allocation for key actions in the sector, especially the Ecole Nationale de la Magistrature (ENMG). The cumulative allocation to rural roads, infrastructure for drinking water and safety nets to support communities over the interim period represented 28.4 percent of the savings from debt relief over the same period. The allocation to safety nets fluctuated depending on need, being high during 2002 (economic and political crisis) and 2004 (cyclones), but lower otherwise. The use of interim debt relief has been reported in documents produced by the National Statistical Institute (INSTAT) and discussed with civil society during regional workshops. The outcomes of the reports were also discussed twice a year during supervision missions with the donors.

\footnotetext{
${ }^{3}$ Table 5 in the decision point document presents the detailed plan for the use of the funds freed by the enhanced HIPC Initiative.

${ }^{4}$ This reflects, in particular, the priority given to the Education for All program.
} 
Table 1: Use of HIPC Funds Against the Criteria Set at the Decision Point

\begin{tabular}{|c|c|c|c|c|c|c|}
\hline & $\operatorname{Ref} *$ & 2001 & 2002 & 2003 & 2004 & Average \\
\hline & $\%$ & $\%$ & $\%$ & $\%$ & $\%$ & $\%$ \\
\hline TOTAL & 100.0 & 100.0 & 100.0 & 100.0 & 100.0 & 100.0 \\
\hline \multicolumn{7}{|l|}{ Of which: } \\
\hline Current expenditures & 60.0 & 57.0 & 51.9 & 68.4 & 70.1 & 61.9 \\
\hline Education & 25.0 & 21.0 & 23.6 & 41.4 & 32.0 & 29.8 \\
\hline Recruitment of new teachers & 9.0 & 0.8 & 6.8 & 12.1 & 7.0 & 6.8 \\
\hline Pedagogical material & 3.0 & 2.7 & 2.5 & 1.7 & 0.0 & 1.8 \\
\hline Technical material & 3.0 & 3.8 & 0.0 & 2.1 & 0.0 & 1.6 \\
\hline School feeding & 3.0 & 0.0 & 0.0 & 0.0 & 0.0 & 0.0 \\
\hline Incentive system for rural teacher & 3.0 & 6.1 & 7.0 & 13.2 & 19.9 & 11.3 \\
\hline Literacy campaigns & 2.0 & 0.0 & 0.0 & 0.0 & 0.0 & 0.0 \\
\hline Fund for cultural development centers (libraries etc.) & 2.0 & 7.6 & 7.4 & 12.3 & 5.1 & 8.3 \\
\hline Health & 20.0 & 20.3 & 21.9 & 23.9 & 31.6 & 24.1 \\
\hline Recruitment of medical personnel & 4.0 & 2.9 & 8.1 & 7.2 & 12.1 & 7.4 \\
\hline Supply of drugs & 4.0 & 0.2 & 6.6 & 9.8 & 3.0 & 5.1 \\
\hline Incentive system for rural medical staff in CSB & 3.0 & 0.0 & 0.0 & 0.0 & 0.0 & 0.0 \\
\hline Small equipment in CSBs and CHDs & 3.0 & 12.0 & 4.7 & 5.1 & 14.0 & 8.7 \\
\hline Anti HIV/AIDS campaign & 3.0 & 2.5 & 1.3 & 0.0 & 0.0 & 0.9 \\
\hline Immunization program & 3.0 & 2.7 & 1.2 & 1.8 & 2.5 & 2.0 \\
\hline Institutional reinforcement & 5.0 & 7.4 & 6.3 & 2.0 & 2.9 & 4.6 \\
\hline Justice system & 2.0 & 2.1 & 0.6 & 0.0 & 0.0 & 0.7 \\
\hline Public control organizations & 2.0 & 2.5 & 2.8 & 1.7 & 2.9 & 2.4 \\
\hline Implementation of decentralization strategy & 1.0 & 2.8 & 2.8 & 0.3 & 0.0 & 1.5 \\
\hline Others ( including environment, gender programs) & 10.0 & 8.3 & 0.0 & 1.1 & 3.6 & 3.2 \\
\hline Investment expenditures & 40.0 & 43.0 & 48.1 & 31.6 & 29.9 & 38.1 \\
\hline Roads maintenance fund (FER), rural roads & 20.0 & 23.0 & 21.2 & 19.4 & 0.0 & 16.5 \\
\hline Infrastructure for drinking water & 3.0 & 3.0 & 1.6 & 1.4 & 5.3 & 2.7 \\
\hline Safety net support to communities & 10.0 & 4.4 & 10.9 & 4.9 & 18.2 & 9.2 \\
\hline Other (including electrification) & 3.0 & 9.3 & 10.9 & 3.6 & 5.3 & 7.2 \\
\hline Monitoring system (including full household survey) & 4.0 & 3.2 & 3.5 & 2.3 & 1.1 & 2.6 \\
\hline
\end{tabular}

* As in Table 5 of the Decision Point Document, Madagascar - Enhanced Heavily Indebted Poor Countries Initiative (www.imf.org), and IDA/R2000-229, (12/5/00).

Source: STA 2004, updates Table 5 of the Decision Point Document, Madagascar - Enhanced Heavily Indebted Poor Countries Initiative (www.imf.org), and IDA/R2000-229, (12/5/00).

15. The overall resource envelope for the social sectors has increased over the interim period, mainly due to the increase in the allocation for primary education (Table 2). Social spending increased from 3.5 percent of GDP in 1999 to 5.3 percent of GDP in 2004, albeit below the projected levels at the time of the decision point. ${ }^{5}$ In 2001

${ }^{5}$ The incremental resources from the savings freed by the HIPC interim relief for the social sectors represented 0.4 percent of GDP in 2001, 0.5 percent of GDP in 2002, 0.7 percent of GDP in 2003 and 0.4 percent of GDP in 2004. 
and 2002, the ratio of social spending to GDP was in line with the projection at decision point. However, it declined in 2003 for both education and health sectors. The decline is largely accounted for by the need to re-launch the economy and restore the infrastructure after the crisis in $2002 .{ }^{6}$ The increase in social spending over the interim period, is mainly due to the increase in the allocation for primary and secondary education, whose share increased from 2.1 percent of GDP in 1999 to 3.4 percent of GDP in 2004 (see Table 2). Although it did not translate into an increase in the share of GDP allocated to the sector, health spending, in real terms, increased from FMG 345.5 billion in 1999 to FMG 354 billion in 2004. As reported in Table 4 and in section II.E. on Improved Service Delivery, most of the targets in education and health showed improvements in 2003 after the crisis, and were met despite the lower than projected share of social spending in GDP .

\section{Since the decision point, the Government, with the support of the donor community, focused on improving its ability to use public resources effectively.}

Accordingly, a number of actions were undertaken by the Government to improve poverty reducing expenditure tracking mechanisms. First, the activities and programs financed with debt relief savings were identified in the budget by a special code to facilitate tracking of these expenditures. Second, three HIPC expenditure tracking assessments were undertaken in 2001, 2003 and 2004. These assessments show that the system of public financial management has improved, albeit slowly. Four out of 16 benchmarks $^{7}$ were met, and three others showed improvements. With the implementation of the reforms supported under the PRSCs, the number of benchmarks met is expected to increase from 4 in 2004 to 6 in 2005, and to at least 10 in 2006.

\footnotetext{
${ }^{6}$ The Government's reconstruction program was supported by the Emergency Economic Recovery Credit (EERC) and comprised, among others: (i) reimbursement of VAT to enterprises (US\$91.5 million); (ii) support to strategic public enterprises and rehabilitation of destroyed infrastructure (US\$88.5 million); assistance to the national airline; assistance to the Northern railway; rehabilitation of destroyed bridges and road infrastructure due to the cyclone Kesiny in 2002. Source: EERC - Madagascar.

${ }^{7}$ The 2003 HIPC Assessment and Action Plans (AAP) showed that 4 out of 16 benchmarks were met. The benchmarks met included (i) government budget not funded through extra-budgetary resources to a significant degree; (ii) budget classification system allows for administrative, economic, functional basis; (iii) poverty related expenditure is clearly identified in the budget; and (iv) tracking surveys are used to supplement internal controls. In 2004 (in draft still), 3 out of the original 16 benchmarks were met, but the benchmark on clear identification of poverty expenditures was downgraded, because only HIPC expenditures are separately identified. An additional benchmark was met for integrating multi-year projections into the budget cycle. In addition, two indicators for budget reporting improved, as did the indicator on the accumulation of arrears.
} 
Table 2: Social Expenditure Before and After Interim Assistance (in billions of FMG, unless otherwise indicated)

\begin{tabular}{|c|c|c|c|c|c|c|c|}
\hline & 1998 & 1999 & 2000 & 2001 & 2002 & 2003 & 2004 \\
\hline Social spending before HIPC assistance & 711.3 & 1037.6 & 1258.5 & 1358.0 & 1598.8 & 1344.0 & 1907.7 \\
\hline Health & 199 & 345.5 & 464.2 & 479.1 & 537.0 & 419.7 & 441.1 \\
\hline Education & 512.3 & 692.1 & 794.3 & 879.2 & 1061.8 & 924.4 & 1466.6 \\
\hline Of which: primary and secondary education & 413.8 & 496.3 & 600 & 713.7 & 870.1 & 751.6 & 1253.4 \\
\hline $\begin{array}{l}\text { Social spending before HIPC assistance (in } \\
\text { percent of GDP) }\end{array}$ & 3.5 & 4.5 & 4.8 & 4.5 & 5.3 & 3.9 & 4.8 \\
\hline Health & 1.0 & 1.5 & 1.8 & 1.6 & 1.8 & 1.2 & 1.1 \\
\hline Education & 2.5 & 3.0 & 3.0 & 2.9 & 3.5 & 2.7 & 3.7 \\
\hline Of which: primary and secondary education & 2.0 & 2.1 & 2.3 & 2.4 & 2.9 & 2.2 & 3.2 \\
\hline Total HIPC-financed spending & & & & 325.0 & 318.1 & 363.1 & 285.1 \\
\hline Health & & & & 66.0 & 70 & 87 & 90.1 \\
\hline Education & & & & 68.2 & 75 & 150 & 91.4 \\
\hline Of which: primary and secondary education & & & & 68.2 & 73.4 & 150 & 91.4 \\
\hline Institutional development and PRSP monitoring & & & & 48.7 & 65.7 & 33.9 & 59.6 \\
\hline Rural roads & & & & 74.9 & 67 & 71 & 0.0 \\
\hline Water supply, environment and other & & & & 67.2 & 39.7 & 22 & 44.0 \\
\hline $\begin{array}{l}\text { Total HIPC-financed spending (in percent of } \\
\text { GDP) }\end{array}$ & & & & 1.1 & 1.0 & 1.1 & 0.7 \\
\hline Health & & & & 0.2 & 0.2 & 0.3 & 0.2 \\
\hline Education & & & & 0.2 & 0.3 & 0.4 & 0.2 \\
\hline Of which: primary and secondary education & & & & 0.2 & 0.2 & 0.4 & 0.2 \\
\hline Institutional development and PRSP monitoring & & & & 0.2 & 0.2 & 0.1 & 0.2 \\
\hline Rural roads & & & & 0.3 & 0.2 & 0.2 & 0.0 \\
\hline Water supply, environment and other & & & & 0.2 & 0.1 & 0.1 & 0.1 \\
\hline $\begin{array}{l}\text { Social spending including HIPC-financed } \\
\text { expenditures }\end{array}$ & & & & 1492.5 & 1743.9 & 1581.2 & 2089.2 \\
\hline Health & & & & 545.1 & 606.9 & 506.4 & 531.2 \\
\hline Education & & & & 947.4 & 1137.0 & 1074.8 & 1558.0 \\
\hline Of which: primary and secondary education & & & & 781.9 & 943.5 & 902.0 & 1344.8 \\
\hline $\begin{array}{l}\text { Social spending including HIPC-financed } \\
\text { expenditures (in percent of GDP) }\end{array}$ & & & & 5.0 & 5.8 & 4.7 & 5.3 \\
\hline Health & & & & 1.8 & 2.0 & 1.5 & 1.3 \\
\hline Education & & & & 3.2 & 3.8 & 3.2 & 4.0 \\
\hline Of which: primary and secondary education & & & & 2.6 & 3.1 & 2.7 & 3.4 \\
\hline Nominal GDP & 20,343 & 23,379 & 26,242 & 29,843 & 30,042 & 33,893 & 39,446 \\
\hline
\end{tabular}

Source: STA 2004; This table shows the budget allocations and updates Table 6 of the decision point document. 
17. Similarly, the monitoring system has been strengthened. The Government has established a Poverty Monitoring System to follow progress in implementing the PRSP. An indicator system with the corresponding sources (Tableau de Bord Social) has been produced regularly from 2001. A multi-topic household survey (Enquête Prioritaire auprès des Ménages, EPM) was conducted in 2001. A follow-up 2004 EPM survey will commence shortly and enable the Government to update its trends in poverty and monitor progress in implementing the PRSP. Finally, a poverty map, based on 1993 data, was constructed in 2002. But many challenges remain and technical assistance is being provided by the donors to strengthen the monitoring and evaluation system of the PRSP, and to improve budget monitoring systems.

\section{The updated indicators ${ }^{8}$ show that most of the targets were achieved (see} Table 4). The share of the budget of the Ministry of Education allocated to the primary schools, and that of the Ministry of Health budget allocated to district health centers and hospitals exceeded the targets. In education, the enrolment rates increased; however, while showing some improvements, repetition rates and primary school completion rates remained below the targets. In health, immunization rates improved. Other health indicators (such as the percentage of births attended by professionals or the medical consultation rates) were below target until 2002, but in 2003, they met or exceeded their targets, and the drug procurement agency's revenues showed a steady increase. The Road Maintenance Fund (FER) allocated an increasing share to rural roads over the period, increasing to over 10 percent in 2002 and beyond.

\section{Governance and Institutional Reforms}

19. As elaborated in the HIPC Decision Point Document, the key challenge in this area is the reform of the public finance system to improve budget formulation, execution, control, monitoring, and auditing to increase transparency and efficiency in spending.

20. The reforms supported under the HIPC Initiative are now part of an overall program aiming to improve the public financial management system. These reforms were based on several diagnostic studies, including the Country Financial Accountability Assessment (CFAA) and the Country Procurement Assessment Report (CPAR) conducted by IDA, the European Union, and the IMF. To further operationalize the reforms, a Priority Action Plan for 2004 was developed and approved by the Government in 2003, in collaboration with the relevant development partners. The PRSC process also supports the Government's reform program and reflects the need to improve budget execution, reporting, and overall monitoring of results.

\section{The Government has implemented the conditions for improving governance} (see Box 1).

- The Government has updated the existing legal, procedural, and institutional framework. Accordingly, the regulations governing the control mechanisms have been adjusted through the adoption of a range of legislative texts to reflect the institutional changes and the recommendations to improve operational efficiency.

\footnotetext{
${ }^{8}$ As outlined in Table 4 of the Decision Point Document.
} 
In accordance with the recommendations of the CFAA, a new internal control cadre in the Ministry of Finance, the General Inspectorate for Finances (IGF), had also been introduced in 2003 and became operational in June 2004. These reforms were complemented by significant investments in human resources. Staffing for the National Audit Court (Chambre des Comptes), the Directorate for Expenditure Commitment Control (CDE) and the State Inspectorate General (IGE) has been improved, and adequate staff has been selected for the newly created IGF. In addition, the different offices have been modernized to enhance the operational efficiency.

- A monitoring system to track budgetary execution in six ministries (health, basic education, public works, rural development, justice, and forestry and water) has been put in place. Periodic reports monitoring the execution rates at each stage of the budgetary cycle were produced for the six ministries. For education and health, to better monitor progress on social spending at the central and decentralized levels, the reports on budgetary cycle for the 2001-03 period have been complemented by an assessment of the corresponding physical outcomes (see Box 1). The monitoring results are discussed with the development partners on a regular basis.

- The treasury accounting system was modernized and strengthened. The main objective is to ensure that government accounts are produced in a timely manner in accordance with statutory requirements. A new unit (Consolidation and Audit Unit) has been established in the Ministry of Finance to address the shortcomings in producing final accounts. As a result of the work of this unit, the 1999 and 2000 budgetary execution laws were prepared and submitted to the National Audit Court (Chambre des Comptes), but later than envisaged in the decision point document due to the 2002 crisis. The final accounts for 2001 and 2002 were submitted in December 2003 and June 2004, respectively. The final accounts for 2003 will be submitted by the end of 2004 . This paves the way for the National Audit Court to submit audited accounts to Parliament and initiate parliamentary approval on the basis of the annual budgetary execution law (loi de règlement).

- Finally, a public and transparent information system on granting of licenses (beneficiary list, geographical zone, and the amount of fees) in the mining, forestry, and fishing sectors has been implemented. The completion of this reform took longer than expected. Prior to 2004, the information system was partial, including only the list of beneficiaries and the geographical zone without mentioning the fees paid by the operators. A comprehensive information system, according to the terms spelled out in the decision point document has now been established. ${ }^{9}$ The Government provided an action plan with the calendar of publication to sustain this reform.

\footnotetext{
${ }^{9}$ Information on license adjudication, specifying beneficiaries, geographic locations, and amounts of fees was published in the newspapers for the fishing sector (December 2003), the forestry sector (February 2004), and the mining sector (April 2004).
} 


\begin{tabular}{|c|c|c|}
\hline \multicolumn{3}{|c|}{$\begin{array}{c}\text { Box 1: Status of Triggers for the Floating Completion Point } \\
\text { Under the Enhanced HIPC Initiative }\end{array}$} \\
\hline Triggers & Status & Comments \\
\hline \multicolumn{3}{|c|}{ GOVERNANCE AND INSTITUTIONAL REFORMS } \\
\hline \multicolumn{3}{|c|}{ A1. Improve financial monitoring and control } \\
\hline $\begin{array}{l}\text { (a) Control systems have been } \\
\text { strengthened through: }\end{array}$ & Completed & $\begin{array}{l}\text { Reforms cover the National Audit Court and the } \\
\text { Procurement Commission. The related action } \\
\text { plan centers on reforming the statutes governing } \\
\text { these agencies, including assigning external } \\
\text { auditing functions to the Procurement } \\
\text { Commission and internal auditing functions to } \\
\text { the State Inspectorate General (IGE). }\end{array}$ \\
\hline $\begin{array}{l}\text { (i) adoption of an appropriate legal and } \\
\text { constitutional framework; }\end{array}$ & Completed & $\begin{array}{l}\text { Revised legislative texts were approved by the } \\
\text { Parliament and the Senate between December } \\
2003 \text { and July } 2004 \text {. }\end{array}$ \\
\hline $\begin{array}{l}\text { (ii) adoption of procedures and internal } \\
\text { control systems that conform to interna- } \\
\text { tional technical standards; and }\end{array}$ & Completed & $\begin{array}{l}\text { Detailed procedural manuals, increased } \\
\text { reporting obligations of public institutions are } \\
\text { fully completed. }\end{array}$ \\
\hline $\begin{array}{l}\text { (iii) an increase in staffing and resources } \\
\text { of the State Inspectorate General (IGE) } \\
\text { and the Commitment Control Office } \\
(C D E)\end{array}$ & Completed & $\begin{array}{l}\text { Additional staff were recruited for the agencies. } \\
\text { Additional resources have been allocated to the } \\
\text { agencies. }\end{array}$ \\
\hline $\begin{array}{l}\text { (b) A monitoring system for the } \\
\text { budgetary cycle has been designed and } \\
\text { implemented in at least six ministries, } \\
\text { including the Ministries of Basic } \\
\text { Education and Health. }\end{array}$ & $\underline{\text { Completed }}$ & $\begin{array}{l}\text { The budget monitoring system is operational for } \\
\text { the Ministries of Health, Basic Education, Public } \\
\text { Works, Rural Development, Forestry and Water, } \\
\text { and Justice. }\end{array}$ \\
\hline $\begin{array}{l}\text { (c) Starting in 2001, the centralization } \\
\text { procedures and consolidation of all } \\
\text { balances of the principal treasury offices } \\
\text { by the Central Treasury Accounting } \\
\text { Office (ACCT) has been improved, } \\
\text { through the formation of a consolidation } \\
\text { and audit unit, constituting a step toward } \\
\text { the establishment of general balance sheet } \\
\text { statements and of reliable opening and } \\
\text { closing accounting balances. }\end{array}$ & Completed & $\begin{array}{l}\text { In } 2001 \text {, all the } 22 \text { principal treasury offices } \\
\text { were computerized and a new unit } \\
\text { (Consolidation and Audit Unit) has been } \\
\text { established in the Ministry of Finance. The } \\
\text { balances for } 1999 \text { to } 2003 \text { were established. }\end{array}$ \\
\hline $\begin{array}{l}\text { (d) The } 1999 \text { budgetary execution law has } \\
\text { been prepared during } 2001 \text { and that of } \\
2000 \text { by end-June } 2002 \text {. }\end{array}$ & $\frac{\text { Completed, }}{\underline{\text { but not in }}}$ & $\begin{array}{l}\text { The } 1999 \text { and } 2000 \text { budgetary execution laws } \\
\text { were prepared and submitted to the National } \\
\text { Audit Court but with delays due to the } 2002 \\
\text { crisis. The } 1999 \text { and } 2000 \text { laws were submitted } \\
\text { in December } 2002 \text { and July/September } 2003 \text {, } \\
\text { respectively. The } 2001 \text { and } 2002 \text { laws were } \\
\text { submitted in December } 2003 \text { and June } 2004 \text {, } \\
\text { respectively. The } 2003 \text { law will be submitted by } \\
\text { end-2004. }\end{array}$ \\
\hline
\end{tabular}




\begin{tabular}{|c|c|c|}
\hline \multicolumn{3}{|c|}{$\begin{array}{l}\text { Box 1: Status of Triggers for the Floating Completion Point } \\
\text { Under the Enhanced HIPC Initiative (concluded) }\end{array}$} \\
\hline Triggers & Status & Comments \\
\hline $\begin{array}{l}\text { A2. Biannual reports on education and health } \\
\text { sector activities at the central and decentralized } \\
\text { level, have been prepared including: }\end{array}$ & $\underline{\text { Completed }}$ & \\
\hline $\begin{array}{l}\text { (i) budgetary allocation and expenditure } \\
\text { execution; and }\end{array}$ & Completed & $\begin{array}{l}\text { Quarterly reports on budgetary allocation } \\
\text { and expenditure execution are being } \\
\text { regularly compiled. }\end{array}$ \\
\hline (ii) physical achievements. & Completed & $\begin{array}{l}\text { The first physical outcome reports were } \\
\text { completed and discussed with the donor } \\
\text { community. }\end{array}$ \\
\hline $\begin{array}{l}\text { A3. A public and transparent information } \\
\text { system on granting licenses (beneficiary list, } \\
\text { geographical zone, and amount) in the mining, } \\
\text { forestry, and fishing sectors has been } \\
\text { implemented, and beneficiary list is published } \\
\text { biannually. }\end{array}$ & Completed & $\begin{array}{l}\text { The process was completed in the first } \\
\text { semester of } 2004 \text {, with the required } \\
\text { information published in the newspapers } \\
\text { for fishing in December } 2003 \text {, for forestry } \\
\text { in February 2004, and for mining in April } \\
\text { 2004. The information system is now in } \\
\text { place. }\end{array}$ \\
\hline $\begin{array}{l}\text { B. IMPROVED SERVICE DELIVERY } \\
\text { B1. Teacher availability in rural areas has } \\
\text { been expanded by: }\end{array}$ & & \\
\hline $\begin{array}{l}\text { (i) formalizing and implementing new financial } \\
\text { incentives for teachers to serve in rural public } \\
\text { primary schools; and }\end{array}$ & Completed & $\begin{array}{l}\text { The system of financial incentives for } \\
\text { teachers to serve in rural areas has been } \\
\text { formalized and implemented. }\end{array}$ \\
\hline $\begin{array}{l}\text { (ii) recruiting at least } 3,500 \text { new teachers from } \\
2000 \text { for public primary schools and deploying } \\
\text { at least } 60 \text { percent of them to schools with either } \\
\text { FRAM-paid teachers or with a ratio of pupils to } \\
\text { publicly paid teachers in excess of } 50 \text {. }\end{array}$ & $\begin{array}{l}\text { Numerical } \\
\text { target not } \\
\text { met, but } \\
\text { satisfactory } \\
\text { progress } \\
\text { achieved }\end{array}$ & $\begin{array}{l}3427 \text { teachers were recruited. } 89 \text { percent of } \\
\text { them were deployed to remote areas. In } \\
\text { addition, the salaries of } 8000 \text { teachers } \\
\text { hired by parent-school associations were } \\
\text { partially paid for. }\end{array}$ \\
\hline $\begin{array}{l}\text { B2. The generic essential drug supply system } \\
\text { of district pharmacies has been rendered } \\
\text { operational, including the start-up of generic } \\
\text { drug supply for hospital outpatients, as } \\
\text { measured by the increase in annual gross } \\
\text { revenues of the existing central purchasing } \\
\text { pharmacy. }\end{array}$ & $\underline{\text { Completed }}$ & $\begin{array}{l}\text { The central purchasing pharmacy } \\
\text { (SALAMA) is fully operational and its } \\
\text { annual gross revenues have been } \\
\text { increasing, reaching FMG } 49,1 \text { billion in } \\
\text { 2003. In parallel, the generic essential drug } \\
\text { supply system of district pharmacies has } \\
\text { been rendered operational. }\end{array}$ \\
\hline $\begin{array}{l}\text { B3. Current road maintenance needs are } \\
\text { covered } 100 \text { percent through the Road } \\
\text { Maintenance Fund, of which at least } 10 \text { percent } \\
\text { are used for rural roads. }\end{array}$ & $\underline{\text { Completed }}$ & $\begin{array}{l}\text { All current road maintenance needs are } \\
\text { covered by the Road Maintenance Fund, } \\
\text { and } 10 \text { percent in } 2002 \text { and } 10.9 \text { percent in } \\
2003 \text { were allocated to rural roads. }\end{array}$ \\
\hline
\end{tabular}




\section{E. Improved Service Delivery}

22. Improving human capital is the third pillar of the PRSP. In education, as set out in the HIPC decision point document, Madagascar's main challenge lies with increasing enrolments and improving the efficiency of the education system and public expenditures, as outlined in the previous National Education Program (PNAE II) and the recent Education Sector Strategic Plan, by providing universal access to grade 1 with the Education For All program, raising survival rates to the end of the cycle, and reducing grade repetition in all grades.

\section{As noted in Box 1, the Government has broadly met the trigger for better} teacher availability in rural areas by implementing new financial incentives for teachers to serve in rural public primary schools (through an increase in the hardship allowances for teachers in remote areas). ${ }^{10}$ In addition, 3,427 teachers were recruited since 2001 for public primary schools. The majority of the newly recruited teachers, that is 89 percent, were deployed in rural areas (zones 2 and 3), ${ }^{11}$ where either teachers were paid by parent-school associations (FRAM) or the ratio of pupils to publicly-paid teachers was in excess of 50. Less than 3,500 teachers were formally recruited, but it is worth noting that the Government has also compensated communities for the salaries of 8,000 teachers paid for by parents - school associations (FRAM). Although the ratio of pupils to teachers showed a slight downward trend, it still remains high in remote areas due to the net increase in enrollments as explained below.

Table 3: Distribution of Primary Teachers across Zones

\begin{tabular}{|c|c|c|c|c|c|c|c|c|}
\hline \multirow[b]{2}{*}{ ZONE* } & \multicolumn{4}{|c|}{$2002-03$} & \multicolumn{4}{|c|}{ 2003-04 } \\
\hline & $\begin{array}{c}\text { Number of } \\
\text { students }\end{array}$ & $\begin{array}{l}\text { Publicly } \\
\text { paid } \\
\text { teachers }\end{array}$ & $\begin{array}{c}\text { Parent- } \\
\text { school } \\
\text { association } \\
\text { paid } \\
\text { teachers } \\
\end{array}$ & $\begin{array}{l}\text { Ratio of } \\
\text { pupils to } \\
\text { teachers }\end{array}$ & $\begin{array}{c}\text { Number of } \\
\text { students }\end{array}$ & $\begin{array}{l}\text { Publicly } \\
\text { paid } \\
\text { teachers }\end{array}$ & $\begin{array}{c}\text { Parent- } \\
\text { school } \\
\text { association } \\
\text { paid } \\
\text { teachers }\end{array}$ & $\begin{array}{l}\text { Ratio of } \\
\text { pupils to } \\
\text { teachers }\end{array}$ \\
\hline 0 & 140,760 & 3,360 & 164 & 42.0 & 128,909 & 2,612 & 137 & 49.0 \\
\hline 1 & 628,737 & 11,013 & 1,838 & 57.0 & 588,455 & 11,291 & 2,519 & 52.0 \\
\hline 2 & 228,287 & 9,570 & 2,015 & 66.0 & 707,569 & 125,000 & 3,338 & 57.0 \\
\hline 3 & 876,559 & 14,567 & 3,090 & 60.0 & $1,143,778$ & 19,476 & 6,191 & 59.0 \\
\hline Total & $2,274,443$ & 38,509 & 7,107 & 59.0 & $2,568,711$ & 45,879 & 12,185 & 56.0 \\
\hline
\end{tabular}

* For the zone 0 that corresponds to urban area, no hardship allowances are established.

Source : Ministry of Education and Research.

${ }^{10}$ In addition, for the first year (2004) of the EFA plan implementation, a contract to construct 110 houses for teachers in remote areas is underway.

${ }^{11}$ The classification is based on the accessibility and remoteness of the areas. 


\section{The savings from HIPC relief also supported the implementation of the Education For All Plan, in particular the following:}

(a) Provision of grants to all primary schools following the Government's declaration for free and compulsory primary education in $2002 .{ }^{12}$

(b) Contribution to the salary of parent-school associations (FRAM) paid teachers in order to alleviate education costs for the poorest families. About 8,000 teachers were paid every year through the HIPC released budget funds. ${ }^{13}$

(c) Provision of furniture for disadvantaged public primary schools in 2003 in remote rural areas.

(d) School stationary for students from the poorest families $(509,000$ students in 2002 and $1,227,000$ in 2003).

(e) Refurbishing of 26 teacher training institutions to train about 2,000-3,000 new teachers per year according to the EFA Plan.

25. The outcomes achieved in service delivery in the education sector were the result of the combined HIPC program and the action plan spelled out in the PRSP. In addition to the scheduled actions in the HIPC program, the key measures to improve primary education over the period of 2002-04 include (i) elimination of school fees for public primary schools; (ii) strengthening of local district and community schools links; (iii) provision of more textbooks (in order to reach a ratio of one textbook per student), student kits and kits for teachers; (iv) implementation of cash payments to the parentschool associations (FRAM) for pedagogical improvements in the schools and assisting children from the poorest families with additional school costs; (v) restructuring of management in the districts (CISCOs); and (vi) improving data collection and monitoring mechanisms at the districts, sub-districts (ZAPs), and school levels.

26. The reforms implemented in the education sector have shown positive results. The net enrollment rate in primary education increased from 67 percent in 2000/01 to 84 percent in 2003/04; the survival rate between grades 1 and 5, although still low, increased from 21 percent to 30 percent, but high repetition rates remain a concern. In 2003, a system of automatic promotion between grades 1 and 2 and between grades 3 and 4 to bring the high repetition rate under control, and regulations related to school management to increase student learning time and to improve student learning outcomes were passed. In 2004, the government has also prepared and issued clear guidelines for the districts and schools aiming to reduce repetition and drop out rates at the primary and secondary levels.

\footnotetext{
${ }^{12}$ Local school committees (comprised of parents, school head, and community representatives) were created to manage school grants. To ensure transparency in the use of school grants, reports on expenditures were publicly posted at school level. While in 2002 , only 75 percent of primary schools received the assigned budget, by 2003, almost all primary schools received the corresponding budget at the beginning of the school year. ${ }^{13}$ However, the success of this action is dampened since the number of parent-school association (FRAM) paid teachers increased significantly (to about 12,000 in 2003) due to massive student enrollment.
} 


\section{Consolidating the achievements during the interim period remains a}

challenge. A human resource rationalization plan, policies on teacher recruitment (including the recruitment of FRAM teachers), incentive arrangements for remote postings, (pre- and in-service) teacher training and teacher deployment, as well as the criteria for the construction of new classrooms need to be reviewed.

28. In health, as set out in the HIPC document at the decision point, the main challenge is to improve access to basic health facilities for the majority of the rural population, and thereby help improve health outcomes. Policy actions to achieve these objectives include the redeployment of medical staff, construction of new health facilities, and increasing the availability of generic drugs. The Government had also planned to prevent the spread of communicable diseases and, in particular, to stabilize the HIV/AIDS prevalence rate, by developing a multi-sectoral national strategy.

29. The government has complied with the condition calling for the setting up of a generic essential drug supply system of district pharmacies. The drug distributor, SALAMA, is operational (including the startup of generic drug availability for hospital outpatients), and annual gross revenues have increased steadily over the last three years (see Table 4). A number of actions to expand rural health facilities have also been implemented. Between 2000 and 2003, accessibility to basic health services (57 percent for less than $5 \mathrm{~km}$ ) improved slightly with the construction of 109 new health facilities, ${ }^{14}$ the increase in non-salary budget allocation to the districts (from 27.7 percent in 2000 to 37.8 percent in 2003$)^{15}$ and the expansion of the private non-profit sector activities in rural areas in social marketing of basic health products. ${ }^{16}$

30. Based on the annual statistical report of the Ministry of Health, many public health indicators, including MDGs, have improved over the interim period (Table 4). ${ }^{17}$ The proportion of deliveries attended by skilled medical staff increased modestly from 20.2 percent in 2000 to 24.2 percent in $2003 .{ }^{18}$ The immunization rate increased from 70.9 percent in 1999 to 85.1 percent in 2003. The curative medical consultation rate at public and private primary health care centers improved significantly from 42 percent in 1999 to 60 percent in 2003 due to the redeployment of medical staff in rural areas - 887 doctors and 395 nurses and midwives since 1999 — and the distribution

\footnotetext{
${ }^{14}$ However, since many inadequate health facilities were no longer staffed, effective coverage was lower.

${ }^{15}$ Since the budget execution varied from 81 percent in 2000 to 93 percent in 2003 the net increase was 15,2 percent (SOCS).

${ }^{16}$ These include water purification, impregnated bed nets, chloroquine for home treatment, oral and injectable contraceptives, etc. Starting in 2003, the Ministry of Health relied much more on public-private partnership (PPP) for its own needs by subcontracting the management of nutritional intensive rehabilitation centers in 36 referral hospitals and hiring 2 international NGOs to provide technical assistance in management and planning in the 111 districts.

${ }^{17}$ Although the trends are the same, the staffs have noted a difference between data provided by DHS and the Ministry of Health.

${ }^{18}$ Actual data as measured by DHS 2003 is 54 percent.
} 
of free drugs in 2003. Many programs against transmissible diseases, ${ }^{19}$ which already started previously were consolidated over the interim period, including the HIV/AIDS multi-sector program (Projet Multi-Sectoriel de Prevention du Sida) which is now in its third year of implementation. ${ }^{20}$

31. To consolidate and strengthen the recent progress in the health sector, the Ministry of Health is focusing on improving the performance of existing hospitals prior to further expansion of the hospital network, and improving access to health services in rural areas. Ensuring adequate supplies of generic drugs in pharmacies in districts will require adequate funding from the Government. A reformulation of the national health strategy is under way to provide a clearer vision about the actions to be undertaken to achieve these objectives.

32. Rural roads. Infrastructure improvement, especially in rural areas, is among the Government's key priorities in its poverty reduction strategy. The Government has complied with the condition calling for 100 percent of current road maintenance needs being covered through the Road Maintenance Fund (FER), and has allocated at least 10 percent for rural roads after 2002 (in comparison to 2.3 percent and 3.2 percent in 2000 and 2001, respectively). The achievements during the interim period are part of a broader implementation of the new rural transport policy, which emphasizes the maintenance of rural roads through the FER and its sustainable financing. The HIPC resources were mainly used for current road maintenance $(6,000 \mathrm{~km}$ and 7,200 temporary jobs created), rehabilitation of rural roads (1,670 km and 5,500 jobs), and periodic maintenance/rehabilitation of paved roads (180 km and 540 jobs).

\section{DEBT SUSTAINABILITY OVER THE MEDIUM TERM}

\section{A. Data Reconciliation and Revision of Assistance}

\section{Staffs of IDA and the IMF, together with the Malagasy authorities, have} reviewed the stock of debt as of end-1999 presented in the decision point document. As a result of this exercise, the NPV of the debt owed to some creditors as presented in the Decision Point Document was revised. These revisions arise from discrepancies with the decision point data discovered during consultations with creditors after the decision point document was published. The main revisions are as follows:

\footnotetext{
${ }^{19}$ The fight against malaria included the implementation of annual indoor insecticide spraying campaigns in eligible highland zones, social marketing of impregnated bed nets, and availability of malaria home treatment for children. Interventions to control tuberculosis, control of morbidity due to schistosomiasis, and plague control have also been important elements.

${ }^{20}$ The first national survey conducted in fall 2003 showed that the HIV prevalence in pregnant women was at 1.1 percent, i.e., already at a generalized phase, and the syphilis rate was at 8 percent (active syphilis). An Information-Education-Communication (IEC) program covering the most sensitive sectors, training for doctors and paramedics and the supply of treatment kits covering the main causes of STIs has been set up.
} 
- Multilateral Creditors. The NPV of debt to the EU was revised upward from US\$24 to US\$30 million due to new information provided by the creditor; whereas a revision of projected interest payments warranted a downward revision of the NPV of debt owed to the IMF from US\$55 million to US\$48 million. The decision point estimate of the NPV of debt with respect to the IMF included SDR charges which are normally not considered as a debt liability.

- Bilateral Creditors. The NPV of the debt owed to Russia was revised upward from US\$120 million to US\$128 million to reflect the implementation of the 1997 Paris Club rescheduling as discussions with this creditor were ongoing at the time of the decision point. ${ }^{21}$ Also, based on creditor statements and official confirmation of numbers received in 2001, the NPV of Madagascar's debt with Iraq was revised upward from US\$59 million to US\$72 million.

34. After full implementation of traditional relief mechanisms, the revised end1999 NPV of debt amounts to US\$2,080 million, compared to US\$2,058 million estimated at the decision point (Table 7). The associated HIPC assistance would increase by US $\$ 22$ million in NPV terms, from the decision point estimate of US\$814 million to US\$836 million. ${ }^{22}$ The new common reduction factor with respect to the revised end-1999 debt stock would be 40.2 percent instead of 39.5 percent as estimated in the decision point document (Table 8).

\section{B. Status of Creditor Participation ${ }^{23}$}

35. Madagascar has received assurances of participation in the enhanced HIPC Initiative from creditors accounting for about 90 percent of the NPV of HIPC assistance (as approved at the decision point). Most multilateral creditors, as well as the Paris Club, have been providing interim assistance. The authorities are working toward signing agreements with all remaining creditors.

\section{Multilateral Creditors}

36. Debt relief from multilateral creditors under the enhanced HIPC Initiative amounts to US\$357 million in NPV terms (or 44 percent of total HIPC relief to Madagascar) (Table 8). ${ }^{24}$ IDA, IMF, AfDB, the EU, and the OPEC Fund have granted interim assistance. The International Fund for Agricultural Development (IFAD) and the Arab Bank for African Economic Development (BADEA) have committed to provide the assistance required under the enhanced HIPC Initiative as soon as Madagascar reaches the completion point.

\footnotetext{
${ }^{21}$ Madagascar-Enhanced Heavily Indebted Countries Initiative - Decision Point Document" (www.imf.org), IDA/R2000-229 footnote 7.

${ }^{22}$ Table 16 presents the amount of assistance to be provided by each creditor consistent with the revised HIPC assistance.

${ }^{23}$ The amounts of debt relief in this section refer to HIPC assistance as estimated in the decision point document.

${ }^{24}$ Using revised end-1999 data, debt relief from multilateral creditors would rise by US\$4.9 million.
} 
37. Assistance from IDA. Debt relief from IDA under the enhanced HIPC Initiative approved at the decision point amounts to US\$252 million in NPV terms. This assistance is being delivered through a reduction of 50 percent of the debt service falling due to IDA, on disbursed and outstanding credits to IDA as of end-December 1999. This mechanism, applied over January 2001-February 2020, would provide a cumulative nominal assistance of US $\$ 437$ million. ${ }^{25}$ Of this amount, US $\$ 47$ million has already been delivered as interim assistance during January 2001-December 2003.

38. Assistance from the IMF. Enhanced HIPC assistance from the IMF amounts to US\$22 million in NPV terms (SDR 16.6 million) and due to downward adjustments to the end-1999 debt stock, would be revised to US\$19 million. IMF assistance (SDR 14.73 million) is being delivered through grants from the PRGF/HIPC Trust to Madagascar's Umbrella Account. These resources would cover approximately 26 percent of Madagascar's principal repayment falling due to the IMF during 2001-08. A total of SDR 5.6 million was provided as interim assistance through September 2004.

39. Assistance from the AfDB Group. Enhanced HIPC assistance from the AfDB Group amounts to US\$59 million in NPV terms. Total assistance provided to Madagascar during the interim period amounted to US\$32 million in nominal terms. AfDB's assistance would be provided through a reduction of 80 percent in the debt service payments to the AfDB Group over the period January 2001 to September 2011.

\section{Bilateral and commercial creditors}

\section{Paris Club creditors have agreed in principle to provide their share of} assistance under the enhanced HIPC Initiative (US\$383 million in NPV terms). Interim assistance is provided through a flow rescheduling under Cologne terms. Bilateral agreements have been signed with all Paris Club creditors except Japan. This has not yet been signed due to technical delays. Most creditors have also have indicated that they would provide assistance beyond HIPC relief, estimated to represent about US\$612 million in end-2003 NPV terms.

\section{Non-Paris Club official creditors account for about 9 percent of the debt} relief committed at the decision point. Some non-Paris Club creditors (China, Kuwait, and Saudi Arabia) have provided some debt relief either through cancellations of some loans or flow rescheduling. ${ }^{26}$ One of the commercial creditors has provided its share of HIPC debt relief through a rescheduling in 2001. A small amount of commercial debt was paid down by the authorities as some commercial banks confiscated Madagascar's deposits abroad.

\footnotetext{
${ }^{25}$ As a result of the upward revision of HIPC assistance, IDA assistance to Madagascar would increase to US\$256 million in NPV terms, equivalent to approximately US\$444 million in nominal terms (Table 17).

${ }^{26}$ Libya has recently informed the Bank and the Fund that it will be providing debt relief to HIPC countries on a bilateral and on a case by case basis. This will not affect the 90 percent financing assurances that have been estimated for Madagascar.
} 


\section{Updated Debt Sustainability Analysis}

\section{External Debt Situation at End-2003}

\section{The DSA included in the decision point document has been updated jointly} by the Malagasy authorities and the staffs of the IDA and the IMF. The stock of debt disbursed and outstanding was updated on the basis of end-2003 loan-by-loan information provided by the authorities. This information has been reconciled with creditor statements from all multilateral and Paris Club creditors, as well as with several non-Paris Club creditors. The exchange rates and discount rates used for calculating Madagascar's nominal and NPV debt as of end-2003 are presented in Table 9.

43. Based on the reconciled debt data, Madagascar's nominal stock of disbursed and outstanding external debt reached US\$4,843 million at end-2003, compared with US\$3,950 million at end-1999 (Table 10). ${ }^{27}$ Of this, 54 percent was owed to multilateral creditors, 45 percent to bilateral creditors and 0.3 percent to commercial creditors.

Madagascar's largest official creditor at end-2003 was IDA, accounting for 41 percent of total debt.

44. The NPV of Madagascar's debt at end-2003, after full application of traditional debt relief mechanisms, is estimated at US\$3,053 million, equivalent to 284 percent of the exports of goods and non-factor services. After assuming full delivery of the revised HIPC debt relief, the NPV of external debt would be reduced to US\$2,079 million, equivalent to 194 percent of exports. This represents an increase of 60 percentage points in the NPV of debt-to-exports ratio compared to the decision point projection. Finally, after taking into account additional bilateral debt relief, the NPV of external debt would be reduced to US\$1,467 million, equivalent to 137 percent of exports (Table 11).

Factors explaining the increase of the ratio between end-1999 and end-2003

45. Box 2 presents a decomposition of the factors underlying the 60 percentage points increase in the NPV of external debt-to-exports ratio at end-2003 relative to the ratio projected at the decision point (133 percent against 194 percent). The net increase is the result of several factors, including (i) changes in the discount rates and exchange rates used for the calculation of the NPV of external debt; and (ii) a reduction in exports relative to that predicted at the time of the decision point. Including additional bilateral relief beyond the terms of the enhanced HIPC Initiative, the ratio of the NPV of external debt to exports would fall to 137 percent. The relative importance of each factor is shown in the box below:

\footnotetext{
${ }^{27}$ The debt data are based on parameters prevailing at the end of each year.
} 
Box 2. Breakdown of the Increase of NPV of Debt-to-Export Ratio as of end-2003 1/

\begin{tabular}{|c|c|c|}
\hline & $\begin{array}{c}\text { Percentage } \\
\text { Points }\end{array}$ & $\begin{array}{c}\text { Percent of total } \\
\text { increase }\end{array}$ \\
\hline NPV of debt-to-exports ratio (as projected at Decision Point) & 133.1 & \\
\hline Changes in the Ratio & 60.5 & $100 \%$ \\
\hline 1. Due to changes in the parameters & 33.4 & $55 \%$ \\
\hline$o / w$ due to changes in the discount rates & 26.3 & $44 \%$ \\
\hline$o / w$ due to changes in the exchange rates & 7.1 & $12 \%$ \\
\hline 2. Due to unanticipated new borrowing & -1.3 & $-2 \%$ \\
\hline$o / w$ due to higher than expected disbursements & -0.4 & $-1 \%$ \\
\hline o/w due to lower concessionality of the loans & -0.9 & $-1 \%$ \\
\hline 3. Due to changes in exports & 8.4 & $14 \%$ \\
\hline 4. Arrears accumulated during the interim period & 6.7 & $11 \%$ \\
\hline 5. Other factors $2 /$ & 13.3 & $22 \%$ \\
\hline NPV of debt-to-exports ratio (actual) & 193.6 & \\
\hline Reduction in the ratio due to additional bilateral relief & 56.9 & \\
\hline $\begin{array}{l}\text { NPV of debt-to-exports ratio after bilateral debt relief beyond HIPC } \\
\text { assistance }\end{array}$ & 136.7 & \\
\hline \multicolumn{3}{|c|}{$\begin{array}{l}\text { Sources: Bank-Fund staff estimates. } \\
\text { 1/ NPV of debt-to-exports ratio after enhanced HIPC assistance. } \\
\text { 2/ Due to revisions in the end-99 database and changes in the delivery of assistance compared to the assumptions } \\
\text { in the decision point projections. }\end{array}$} \\
\hline
\end{tabular}

46. Between the decision point and the completion point, Madagascar's export performance was somewhat worse than expected. Despite a high level of exports in 2001 and a rebound in 2003, on average, export performance was weaker than projected at the decision point. This was due to the decline in exports in 2002 when output and exports declined drastically due to the political strife. Decline in exports accounts for 14 percent of the total increase in the ratio (equivalent to 8.4 percentage points).

47. Consistent with the enhanced HIPC Initiative methodology, the DSA at the completion point used updated parameters for the calculation of the NPV of debt. ${ }^{28}$ The changes observed in the exchange and discount rates between the decision point and

${ }^{28}$ The DSA uses end-2003 exchange rates and the six-month average of the CIRR (July-December 2003) as discount rates. 
the completion point resulted in an increase of 33 percentage points in the NPV of debt to exports ratios with discount rates having a large effect. ${ }^{29}$

\section{The remaining changes in the NPV of external debt-to-exports ratio are} explained by a number of factors. New external borrowing, which was lower than anticipated in the decision point document, contributes to reducing the debt ratio by 1 percentage point. Approximately 7 percentage points of the deterioration in the ratio since the decision point can be attributed to arrears accumulated by Madagascar during the interim period. ${ }^{30}$ Finally, other factors not isolated raised the end-2003 ratio by 13 percentage points.

49. Madagascar does not meet the conditions for topping-up. Relative to projections at the decision point, the NPV of external debt-to-exports ratio deteriorated to 194 percent on account of multiple factors as detailed above. However, after including additional bilateral assistance beyond HIPC, the ratio is reduced to 137 percent below the 150 percent HIPC threshold.

\section{External Debt Outlook, 2004-23}

50. The macroeconomic framework has been revised in the context of updating the DSA by the staffs of the IMF and IDA together with the authorities. While maintaining the thrust of the GDP projections in the baseline presented at the time of decision point, the current scenario takes into account the recent high levels of activity in, as well the future prospects for, the construction, mining, and the export processing zones. Over the projection period (2004-23), GDP growth averages 6 percent, slightly lower than the 6.3 percent average growth projected at the decision point. Structural measures to support this growth include public enterprise reforms to improve efficiency, the development of infrastructure to provide access to markets and increase tourism, and measures to improve the business climate (in particular the establishment of a one-stop counter for processing investment related formalities). GDP growth will be underpinned by an average growth in the volume of exports of slightly over 6 percent. On average the import growth at 5.8 percent is slightly weaker than GDP growth as food imports and in particular rice imports grow relatively slowly given the expected increase in domestic agricultural output.

51. The fiscal stance would be prudent and expenditures would be contained to about 20 percent of GDP with the overall deficit (excluding grants) declining gradually from an average of about 9 percent in 2000 to 2006 to less than 4 percent by the end of the projection period. The public expenditure reforms, which are key

\footnotetext{
${ }^{29}$ SDR and U.S. dollar discount rates declined from 5.6 percent to 4.2 percent and from 7.0 percent to 4.5 percent, respectively. The euro discount rate also decreased from 5.5 percent to 4.6 percent (Table 9 ).

${ }^{30}$ These arrears have been to non-Paris Club creditors. While Madagascar has contacted all non-Paris Club creditors regarding the provision of HIPC debt relief, some have not yet responded.
} 
among the structural reforms in Madagascar, are assumed to help increase the revenue-toGDP ratio to about 16 percent by the end of the projection period.

\section{External assistance, which stands at about 13 percent of GDP is gradually} unwound to average about 6 percent of GDP in the projection period ${ }^{31}$ It is assumed that Madagascar will rely more on domestic savings in the medium and long term. Budget support (loans and grants) which is currently about 5.0 percent as a share of GDP is gradually lowered but maintained at an average of about 1.5 percent in the latter half of the projection period as Madagascar will need budget support even in the longer term. All new borrowing is assumed to be at highly concessional (IDA comparable) terms. The composition of external assistance is assumed to shift gradually towards grants, which increases as a share of total external assistance from 50 percent in 2004 to about 60 percent by the end of the projection period. Box 3 summarizes the assumptions underlying the projections for the period 2004-2023:

\section{Box 3: Assumptions Used in the Debt Sustainability Analysis}

- $\quad$ Real GDP growth is assumed to average 6 percent (slightly lower than the 6.3 percent at decision point).

Export volumes are projected to grow at a little over 6 percent (6.2 percent on average) while import volumes grow slightly below GDP growth on average.

The terms of trade decline sharply in 2004, rebound modestly in the first few years and remain stable in the outer years.

Foreign direct investment is assumed to be about 1.5 percent of GDP.

Gross domestic investment increases rapidly in the initial years to a little over 20 percent and decelerates slowly from the middle years to about 9 percent towards the end of the projection. Both public and private investment are high initially, and while public investment decelerates sharply in the later years, private investment remains high at above 10 percent of GDP.

The external current account deficit (excluding grants) declines from over 13 percent in 2004 to a little above 5 percent in the middle years of the projection period. It remains slightly below 5 percent in the subsequent years.

External financing, which is high in the current period, is unwound to average 6 percent of GDP in the projection period. Budget support is gradually unwound from the current high levels, but maintained at about 1.5 percent for the later years of the projection period.

New borrowing is assumed to be at highly concessional (IDA-like) terms and grants are assumed to increase gradually to about 60 percent as a share of total external assistance from the current level of about 50 percent.

\footnotetext{
${ }^{31}$ External assistance as a share of GDP averaged about 6 percent over the last previous years.
} 


\section{Under the above assumptions and thanks to debt relief, the profile of} Madagascar's NPV of external debt as a ratio of exports, which is relatively high in the initial years, is expected to decrease gradually over time (Figure 1). The end-2004 NPV of debt-to-exports, after the full delivery of HIPC assistance, is 214 percent. Although the ratio is projected to come down rapidly, it would remain above the HIPC threshold of 150 percent in the initial five years of the projection period. After additional bilateral assistance, the ratio is projected to be reduced to 154 percent as at end-2004, close to that of non-HIPC low income countries (143 percent) but still high compared to that of developing countries as a whole (120 percent). ${ }^{32}$ From 2005 onwards, the ratio would steadily decline to reach 63 percent by end-2023, after HIPC assistance and additional bilateral debt relief are taken into account (Table 14).

\section{The declining profile of the NPV of external debt-to-exports ratio is} accompanied by lower external debt service ratios. In 2004, after full delivery of HIPC assistance and additional bilateral debt relief, the debt service ratio would fall sharply to about 5 percent of exports, compared to 13 percent after full delivery of traditional debt relief mechanisms. For the period as a whole, the external debt service-to-exports ratio is projected to be relatively stable at about 5 percent on average.

\section{Sensitivity Analysis}

\section{Madagascar will exit from the enhanced HIPC Initiative with improved} chances of attaining debt sustainability, particularly taken the delivery of additional bilateral assistance into account. However, vulnerabilities will remain. The three alternate scenarios below (Figure 2) serve to illustrate the implications for Madagascar's debt burden of a lower GDP growth, a deterioration in the terms of trade, and the effect of a change in the composition of financing towards more loans rather than grants.

\section{Scenario 1. Lower growth}

56. Failure to implement structural reforms could result in lower GDP growth in Madagascar. In this scenario, GDP growth is assumed to be 4 percent in the mediumterm on average, a substantial shock relative to the base case assumption of 6 percent. The volume of exports and imports would grow at approximately the same rate as GDP, i.e., at 4 percent. External assistance as a ratio of GDP is assumed to be the same as in the baseline scenario and borrowing, as in the baseline scenario, is at highly concessional (IDA comparable) terms. Although the profile of most measures of the debt burden would continue to trend downward, the reduction in the debt burden is more limited. By the end of the projection period, the ratios of NPV of debt-to-GDP and to-exports would be higher on average by about 10 and 15 percentage points, respectively, relative to the baseline scenario. The debt service-to-export ratio would start to increase towards the end of the projection period. The current account would deteriorate sharply and with external

\footnotetext{
${ }^{32}$ Ratios for non-HIPC low-income countries and for developing countries are for 2002 and 2001, respectively. See Heavily Indebted Poor Countries (HIPC) Initiative-Status of Implementation, www.imf.org, and IDA/SecM2004-0599.
} 
Figure 1. External Debt and Debt-Service Indicators for Mediumand Long-Term Public Sector Debt, 2003-23

(In percent)
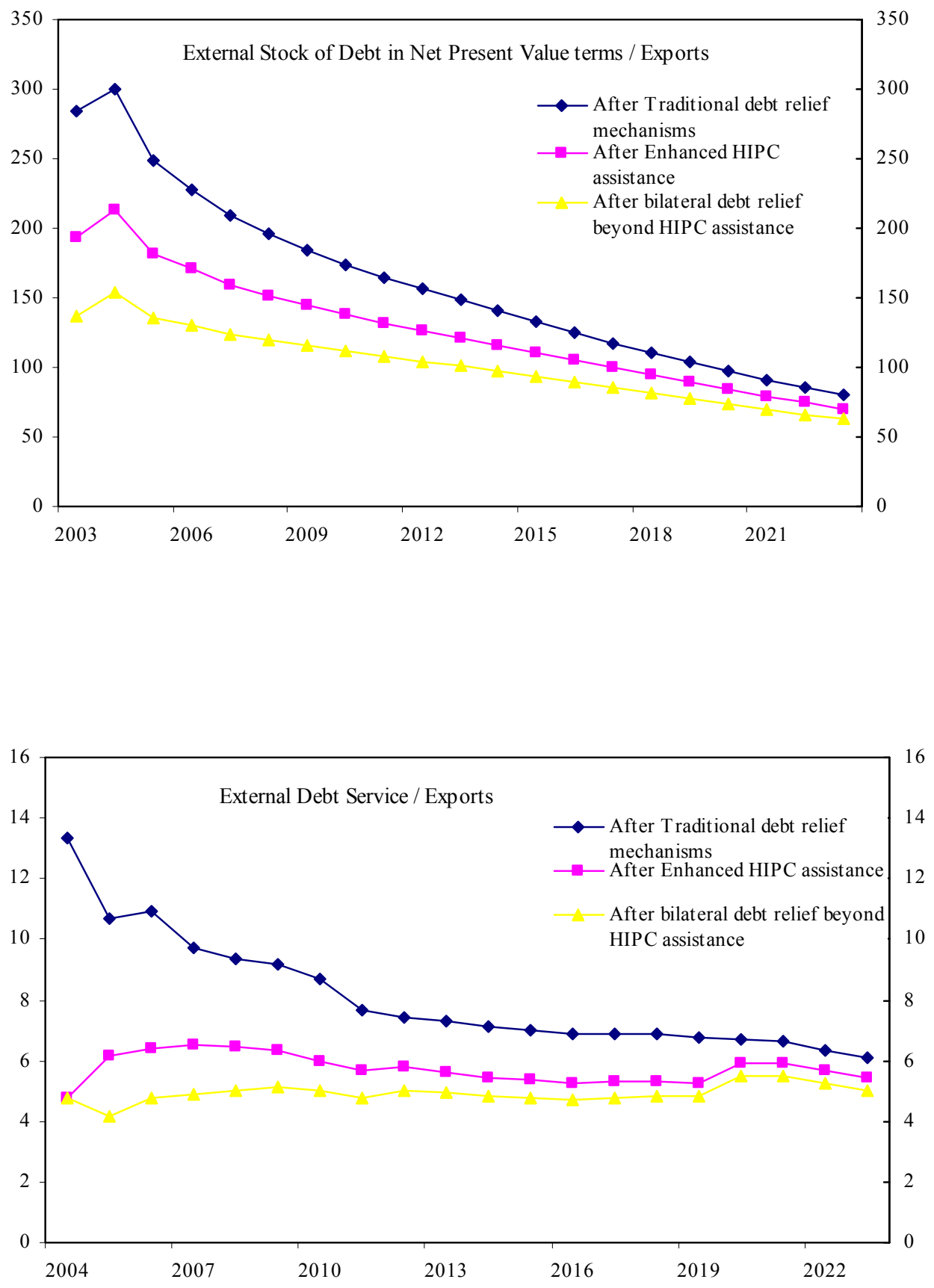
Figure 2. Sensitivity Analysis (In percent)
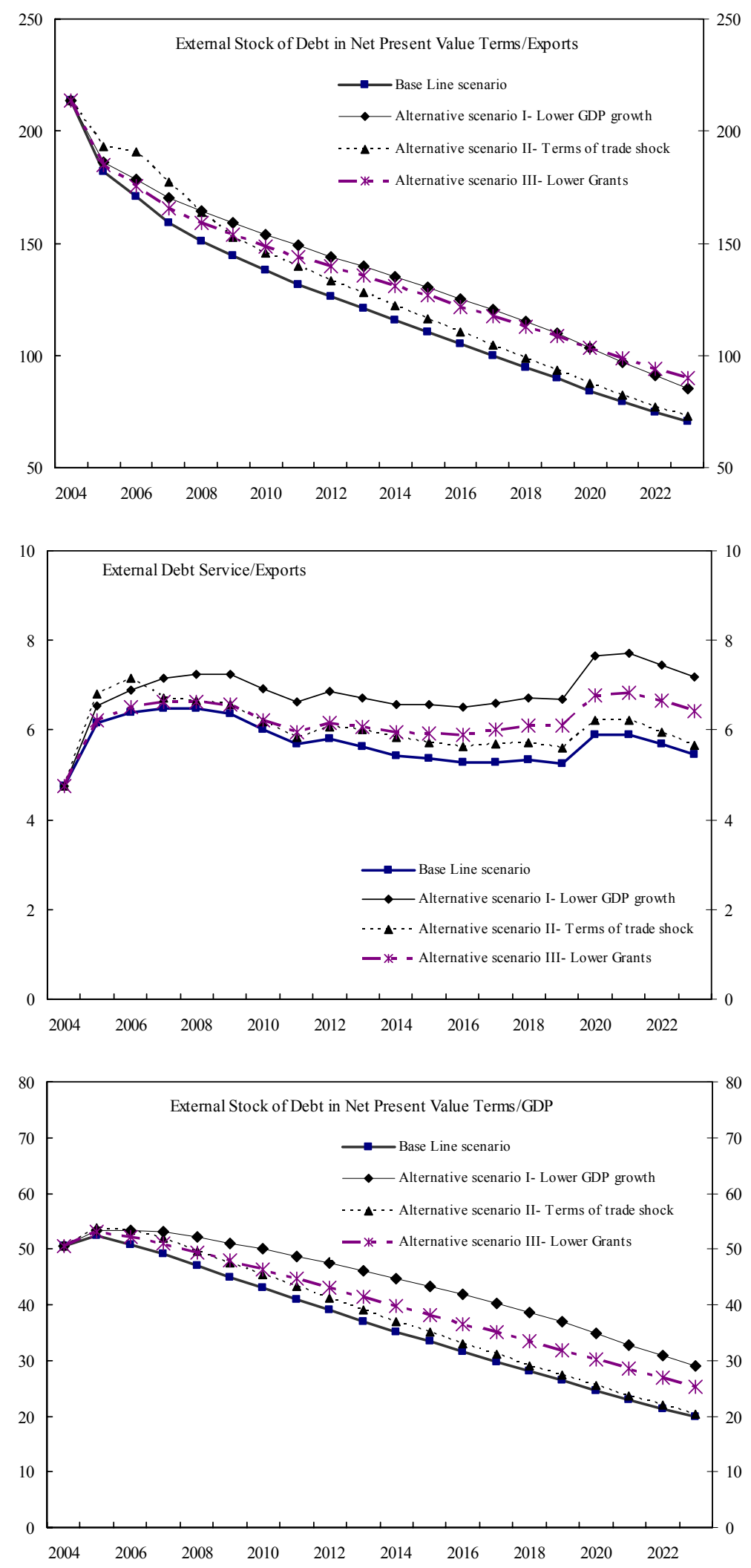
financing assumed not to increase to compensate for shortfalls, central bank reserves would be depleted. ${ }^{33}$

\section{Scenario 2. Lower prices of commodities}

\section{Despite the increasing share of EPZs in Madagascar's exports in recent} years, Madagascar remains susceptible to declines in the prices of commodities, particularly that of vanilla. To illustrate, the price of vanilla and shellfish (two important items in Madagascar's traditional exports) ${ }^{34}$ are assumed to fall sharply in 2005 (by about 50 percent in the case of vanilla), stay at these levels for about two years and reverse gradually in subsequent years. Financing shortfalls (of about US\$85 million a year) are assumed to be met by temporary additional borrowing at concessional terms, such that the international reserves to import ratio is maintained at a reasonable level. Given the concessional nature of the new borrowing, the debt service ratio would increase only marginally and the impact is slightly lower than in the lower GDP growth scenario. As the need for additional new borrowing is only temporary, the debt service ratio trends downwards but remains slightly higher than in the base case scenario. The impact on the debt to export ratio is significant such that the ratio remains higher than in the base case and higher than the HIPC thresholds until after 2010, pointing to the need for the development of appropriate macroeconomic and export policy responses to potential shocks.

\section{Scenario 3. Lower grants and higher loans}

58. This scenario assumes a change in the mix of external assistance with lower grants that are replaced by increased borrowing. As in the baseline scenario, external financing is assumed to be about 6 per cent of GDP on average. The share of grants was reduced by 1 percentage point of GDP in favor of loans relative to the baseline scenario. ${ }^{35}$ Debt service ratios would start to rise towards the end of the period and, while initially the impact on the NPV of debt stock would be small, the debt burden build over time such that the NPV of the stock of debt-to-exports is about 20 percentage points higher relative to the baseline towards the end of the projection period. If the borrowing is done on a non-concessional basis, the impact relative to the baseline scenario would be larger by a further 10 percentage points with respect to the NPV of debt to exports and the debt service-to-export ratio would rise even faster.

\footnotetext{
${ }^{33}$ Borrowing (on even highly concessional terms) in order to maintain a reasonable level of international reserves (three months of imports) would almost double the debt burden measured in term of the NPV of debt as share of exports and GDP. The debt service ratios would also be significantly higher and continue to increase even by the end of 2023 .

${ }^{34}$ These represented a little over 20 per cent of nominal exports over 2002 to 2003.

${ }^{35}$ This is generally in line with the variations in the grant to GDP ratio over the last five years.
} 


\section{Conclusions}

59. The completion point triggers have been broadly met, albeit with a delay in one trigger and a small deviation in a second. The economic and political crisis of 2002 led to a delay in the production and submission of the budget execution laws for 1999 to 2002. In addition, while the number of teachers hired was slightly less than outlined in the decision point document, the government had partially compensated communities for the salaries of 8,000 teachers, without hiring them on the payroll.

60. Taking into account the political strife and exogenous shocks which affected the economy since the decision point, macroeconomic performance has been broadly satisfactory. These factors also affected the speed of the structural reforms which has been somewhat slow. The authorities are committed to maintaining macroeconomic stability and believe that the foundations are in place to this end. They believe that obtaining full debt relief would be critical for further progress.

61. The NPV of Madagascar's debt at end-1999 has been revised upward by US\$22 million. As a result, the required HIPC assistance to Madagascar, in NPV terms, will need to be revised from the decision point estimate of US\$814 million to US\$836 million. Also, the new common reduction factor applicable to the revised end1999 debt stock would be 40.2 percent instead of 39.5 percent as estimated in the decision point document.

62. Madagascar has obtained adequate financing and assurances (conservatively estimated at 90 percent of total HIPC assistance as estimated at the decision point) for HIPC assistance to be delivered on an irrevocable basis.

63. Debt relief at the completion point, including delivery of additional bilateral assistance, together with appropriate macroeconomic policies and structural reforms, would provide Madagascar with the basis to exit from the HIPC Initiative to attain debt sustainability. As the results under the baseline scenario and the sensitivity analysis illustrate, it is critical that sound macroeconomic policies are maintained and that structural reforms are implemented. Measures that aim at the diversification of the economy would be important to maintain growth over the longer term and reduce the impact of large and sustained declines in prices of commodities such as vanilla and shellfish. The authorities would also need to adhere to prudent debt management and continue to borrow only on concessional terms. Debt levels, after delivery of enhanced HIPC assistance, remain relatively high in the initial years but come down after the delivery of additional bilateral assistance. The NPV of debt-to-exports ratio, after the delivery of additional bilateral debt relief, would remain below 150 percent during the complete period of analysis. Therefore, Madagascar does not qualify for a topping-up of HIPC assistance under the topping-up framework.

64. In light of all of these factors, the staffs recommend that the Executive Directors approve the completion point for Madagascar as well as the proposed revision to the enhanced HIPC Initiative debt relief agreed at the decision point. 


\section{ISSUES FOR DISCUSSION}

65. Executive Directors may wish to focus on the following issues and questions:

- Do Directors agree that Madagascar has satisfied the conditions for reaching the completion point under the enhanced HIPC Initiative, as established at the time of the decision point, albeit with delay in the completion of the trigger on budgetary execution laws and a small deviation in the trigger on hiring of teachers?

- Do Directors agree with the staffs recommendation to revise the debt relief to Madagascar under the enhanced HIPC Initiative given the findings of the data reconciliation exercise?

- Do Directors agree that sufficient assurances have been given by Madagascar's other creditors to commit enhanced HIPC Initiative assistance to Madagascar as approved at the decision point and amended in the data reconciliation exercise, on an irrevocable basis?

- Do Directors agree that the debt relief under the HIPC Initiative and bilateral initiatives beyond HIPC will provide Madagascar with a sound basis for debt sustainability?

- Do Directors agree that Madagascar's PRSP and expenditure-tracking mechanism provide assurance that enhanced HIPC Initiative assistance and other resources will further poverty reduction effort? 
Table 4. Madagascar: Monitoring Indicators

\begin{tabular}{|c|c|c|c|c|c|c|c|c|c|}
\hline & \multirow{2}{*}{$\frac{1999}{\text { Reference }}$} & \multicolumn{2}{|c|}{2000} & \multicolumn{2}{|c|}{2001} & \multicolumn{2}{|c|}{2002} & \multicolumn{2}{|c|}{2003} \\
\hline & & Target & $\overline{\text { Realization }}$ & Target & Realization & Target & Realization & Target & Realization \\
\hline $\begin{array}{l}\text { 1. Budget allocation of the Ministry of Primary } \\
\text { and Secondary Education assigned to primary } \\
\text { schools, percent of non-salary } \\
\text { current expenditures: }\end{array}$ & & & & & & & & & \\
\hline HIPC funds not included & & & & & 43.2 & & 49.4 & & 44.0 \\
\hline HIPC funds included & 43.3 & 54.3 & 54.3 & 63.1 & 53.6 & 63.1 & 67.9 & 63.1 & 65.8 \\
\hline $\begin{array}{l}\text { 2. Budget allocation of the Ministry of Health } \\
\text { assigned to district health administrations } \\
\text { and district hospitals, percent of total } \\
\text { non-salary current expenditures: }\end{array}$ & & & & & & & & & \\
\hline HIPC funds not included & & & & & 31.2 & & 29.7 & & 37.8 \\
\hline HIPC funds included & 20.0 & 30.0 & 27.7 & 32.5 & 51.2 & 35.0 & 41.9 & 37.5 & 61.1 \\
\hline $\begin{array}{l}\text { 3. Ratio of public sector procurement prices } \\
\text { and equivalent private sector procurement } \\
\text { prices, Ministries of Education and Health }\end{array}$ & 172.0 & na & nd & 135.0 & 144.0 & 125.0 & & & 125.0 \\
\hline $\begin{array}{l}\text { 4. Curative medical consultation rate of } \\
\text { public and private primary health care }\end{array}$ & & & & & & & & & \\
\hline centers, number per person/year & 0.46 & 0.52 & 0.50 & 0.58 & 0.48 & 0.64 & 0.52 & 0.60 & 0.73 \\
\hline 5. Professionally attended births in all health & & & & & & & & & \\
\hline $\begin{array}{l}\text { care institutions, percent of total } \\
\text { expected births }\end{array}$ & 20.9 & 33.4 & 20.2 & 35.4 & 18.3 & 36.4 & 20.0 & 37.0 & $\begin{array}{r}24.2 \\
(54.2 \mathrm{DHS})\end{array}$ \\
\hline $\begin{array}{l}\text { 6. Caesarien births in all health care institutions, } \\
\text { as percentageof total expected births }\end{array}$ & 0.41 & 0.46 & 0.47 & 0.51 & 0.45 & 0.56 & 0.48 & 0.61 & 0.62 \\
\hline $\begin{array}{l}\text { 7. Immunization rate of DPT } 3 \text { for infants under } \\
\text { age } 1 \text {, percent } 3 \text { / }\end{array}$ & 70.9 & 72.0 & 83.0 & 74.0 & 78.3 & 76.0 & 61.5 & 80.0 & $\begin{array}{r}85.1 \\
(61.4 \mathrm{DHS})\end{array}$ \\
\hline $\begin{array}{l}\text { 8. Realization rate of medical prescriptions in } \\
\text { primary health centers, percent }\end{array}$ & 86.4 & 87.4 & 87.4 & 88.4 & 88.0 & 89.4 & 84.3 & 89.4 & 87.1 \\
\hline $\begin{array}{l}\text { 9. Gross revenue of the central drug } \\
\text { procurement agency, billion of FMG }\end{array}$ & 22.9 & 20.3 & 24.4 & 32.5 & 44.8 & 35.6 & 45.9 & 46.8 & 49.1 \\
\hline $\begin{array}{l}\text { 10. Total enrollments in public and private } \\
\text { primary schools } 4 \text { / }\end{array}$ & & & & & & & & & \\
\hline Number of pupils in grades $1-5$ & $2,018,700$ & $2,208,300$ & $2,208,321$ & $2,329,500$ & $2,307,314$ & $2,456,900$ & $2,405,496$ & $2,488,000$ & $2,510,091$ \\
\hline Number of non-repeaters in grades $1-5$ & $1,348,800$ & $1,573,760$ & $1,597,832$ & $1,610,492$ & $1,610,492$ & $1,901,000$ & $1,673,909$ & $1,737,000$ & \\
\hline $\begin{array}{l}\text { 11. Number of new first grades in public } \\
\text { primary schools }\end{array}$ & 375,000 & 409,200 & 409,264 & 466,000 & 422,752 & 498,100 & 456,561 & 597,700 & 473,283 \\
\hline $\begin{array}{l}\text { 12. Repetition rate, public primary } \\
\text { schools } 5 / \text {, percent }\end{array}$ & 33.0 & 32.0 & 31.2 & $25-30$ & 33.8 & $25-30$ & 34.2 & $20-25$ & 30.0 \\
\hline $\begin{array}{l}\text { 13. Pseudo Cohort Survival Rate at the end } \\
\text { of primary cycle, public primary schools, } \\
\text { percent } 6 /\end{array}$ & 28.0 & na & 28.6 & $30-35$ & 21.7 & $30-35$ & 21.0 & $35-40$ & 30.0 \\
\hline $\begin{array}{l}\text { 14. Percentage of Road Maintenance Fund } \\
\text { spent on rural roads }\end{array}$ & na & 1.0 & 2.3 & 2.0 & 3.2 & 10.0 & 10.3 & 10.0 & 10.9 \\
\hline
\end{tabular}

1/ See I-PRSP, Annexes II, III, and IV.

2/ Percentage of all given prescriptions actually used by patients to obtain drugs.

3/ Vaccination rate against diphtheria, pertussis and tetanus.

4/ Education indicators refer to the preceding school year (e.g., 2001 refers to school year 2000/01.

5/ The I-PRSP (Annex IV) spells out an aggregate target for public and primary school first graders which is consequently higher than the public school target in this list.

6/ The cohort survival rate measures the percentage of all children entering primary school who also complete it. It is "pseudo" as it is derived from cross-sectional data and not from time-series data. 
Table 5. Madagascar: Selected Economic and Financial Indicators, 2001-23 1/

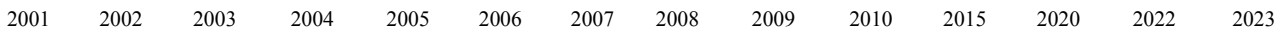

(Annual percentage change, unless otherwise indicated)

\begin{tabular}{|c|c|c|c|c|c|c|c|c|c|c|c|c|c|c|}
\hline \multicolumn{15}{|l|}{ National income and prices } \\
\hline Nominal GDP growth & 13.7 & 0.7 & 12.8 & 16.4 & 16.2 & 12.3 & 11.5 & 11.5 & 11.2 & 11.2 & 11.1 & 11.1 & 11.1 & 11.1 \\
\hline Real GDP growth & 6.0 & -12.7 & 9.8 & 5.3 & 7.0 & 7.0 & 6.3 & 6.3 & 6.0 & 6.0 & 5.9 & 5.9 & 5.9 & 5.9 \\
\hline GDP deflator & 7.3 & 15.3 & 2.8 & 10.5 & 8.6 & 4.9 & 4.9 & 4.9 & 4.9 & 4.9 & 4.9 & 4.9 & 4.9 & 4.9 \\
\hline Consumer price index (period average) & 7.0 & 16.3 & -1.7 & 10.1 & 7.6 & 5.0 & 5.0 & 5.0 & 5.0 & 5.0 & 5.0 & 5.0 & 5.0 & 5.0 \\
\hline Consumer price index (end of period) & 4.8 & 13.9 & -0.8 & 14.9 & 5.0 & 5.0 & 5.0 & 5.0 & 5.0 & 5.0 & 5.0 & 5.0 & 5.0 & 5.0 \\
\hline \multicolumn{15}{|l|}{ External sector } \\
\hline Export, f.o.b & 20.6 & -50.5 & 63.0 & -2.4 & 23.7 & 9.7 & 9.4 & 8.2 & 7.8 & 7.8 & 7.1 & 6.8 & 6.3 & 6.3 \\
\hline Imports, c.i.f. & 5.5 & -37.6 & 70.3 & 8.5 & 8.3 & 5.4 & 6.2 & 5.1 & 6.0 & 6.4 & 6.7 & 7.2 & 6.9 & 6.8 \\
\hline Export volume & 4.4 & -51.2 & 51.8 & -1.2 & 18.1 & 8.8 & 8.0 & 7.2 & 6.7 & 6.8 & 6.2 & 5.9 & 5.4 & 5.5 \\
\hline Import volume & 6.6 & -45.3 & 70.4 & -5.3 & 7.6 & 7.3 & 6.5 & 6.7 & 6.3 & 6.4 & 5.9 & 6.2 & 6.2 & 6.2 \\
\hline Terms of trade (deterioration -) 2/ & 16.6 & -11.0 & 7.4 & -13.9 & 4.1 & 2.6 & 1.5 & 2.4 & 1.3 & 1.0 & 0.1 & -0.2 & 0.2 & 0.3 \\
\hline \multicolumn{15}{|l|}{ Public finance } \\
\hline Revenue (excluding grants) & -1.3 & -20.7 & 45.4 & 35.0 & 20.4 & 14.7 & 15.4 & 14.5 & 14.2 & 13.4 & 13.3 & 11.1 & 11.1 & 11.1 \\
\hline Total expenditure $3 /$ & 26.2 & -10.5 & 40.6 & 37.9 & 12.6 & 10.8 & 9.2 & 7.7 & 10.3 & 10.6 & 11.9 & 9.2 & 10.7 & 10.8 \\
\hline Current expenditure & 28.3 & 0.9 & 24.1 & 18.6 & 11.4 & 9.3 & 11.7 & 12.7 & 12.8 & 13.1 & 13.1 & 13.1 & 13.1 & 13.1 \\
\hline Investment expenditure and net lending & 23.5 & -26.6 & 72.7 & 64.7 & 13.8 & 12.4 & 6.9 & 2.7 & 7.5 & 7.7 & 10.0 & 1.6 & 5.2 & 4.9 \\
\hline & \multicolumn{14}{|c|}{ (In percent of GDP) } \\
\hline \multicolumn{15}{|l|}{ Public finance } \\
\hline Total revenue (excluding grants) & 10.1 & 8.0 & 10.3 & 12.0 & 12.4 & 12.7 & 13.1 & 13.5 & 13.8 & 14.1 & 15.5 & 16.2 & 16.2 & 16.2 \\
\hline Of which: tax revenue & 9.7 & 7.7 & 10.0 & 11.2 & 11.8 & 12.1 & 12.6 & 13.0 & 13.4 & 13.7 & 15.2 & 15.9 & 15.9 & 15.9 \\
\hline Total grants & 3.9 & 2.2 & 5.1 & 7.9 & 5.9 & 5.8 & 5.6 & 5.4 & 5.2 & 5.1 & 4.2 & 3.4 & 3.2 & 3.0 \\
\hline Capital expenditure & 7.3 & 4.8 & 7.8 & 11.5 & 11.3 & 11.3 & 10.8 & 10.0 & 9.7 & 9.3 & 7.9 & 6.3 & 5.6 & 5.3 \\
\hline Total expenditure & 17.6 & 15.7 & 19.5 & 23.1 & 22.4 & 22.1 & 21.7 & 21.0 & 20.8 & 20.7 & 20.3 & 19.8 & 19.6 & 19.5 \\
\hline Overall balance (commitment basis, & & & & & & & & & & & & & & \\
\hline $\begin{array}{l}\text { 1ncl. grants) } \\
\text { Overall balance (commitment basis, }\end{array}$ & -4.3 & -5.5 & -4.2 & -3.4 & -4.1 & -3.7 & -3.0 & -2.1 & -1.7 & -1.5 & -0.5 & -0.2 & -0.2 & -0.2 \\
\hline excl. grants) & -8.2 & -7.7 & -9.3 & -11.3 & -10.0 & -9.5 & -8.6 & -7.5 & -7.0 & -6.6 & -4.8 & -3.6 & -3.4 & -3.3 \\
\hline Domestic financing & 1.9 & 2.4 & 1.8 & -1.1 & 0.0 & 0.0 & -0.1 & 0.1 & -0.1 & 0.2 & 0.1 & 0.1 & 0.0 & 0.0 \\
\hline \multicolumn{15}{|l|}{ Savings and investment } \\
\hline Resource gap & -3.2 & -6.6 & -10.1 & -15.2 & -11.7 & -10.1 & -9.2 & -8.2 & -7.5 & -7.0 & -6.3 & -6.0 & -6.0 & -6.1 \\
\hline Investment & 18.5 & 14.3 & 17.9 & 23.7 & 25.3 & 24.8 & 24.2 & 23.3 & 23.0 & 22.6 & 21.1 & 19.4 & 18.6 & 18.3 \\
\hline Government & 7.3 & 4.8 & 7.8 & 11.5 & 11.3 & 11.3 & 10.8 & 10.0 & 9.7 & 9.3 & 7.9 & 6.3 & 5.6 & 5.3 \\
\hline Nongovernment & 11.2 & 9.5 & 10.1 & 12.2 & 14.0 & 13.5 & 13.4 & 13.3 & 13.3 & 13.3 & 13.2 & 13.1 & 13.1 & 13.1 \\
\hline Gross domestic savings & 15.3 & 7.7 & 7.8 & 8.6 & 13.6 & 14.7 & 15.0 & 15.1 & 15.4 & 15.6 & 14.8 & 13.4 & 12.6 & 12.2 \\
\hline Government & 1.8 & -0.2 & 1.1 & 3.0 & 3.4 & 3.6 & 4.0 & 4.1 & 4.2 & 4.2 & 4.3 & 3.5 & 2.9 & 2.6 \\
\hline Nongovernment & 13.5 & 7.9 & 6.7 & 5.6 & 10.2 & 11.1 & 11.0 & 11.1 & 11.2 & 11.4 & 10.5 & 9.9 & 9.7 & 9.6 \\
\hline Gross national savings & 17.2 & 8.3 & 11.9 & 14.6 & 17.5 & 18.5 & 18.6 & 18.5 & 18.6 & 18.6 & 17.3 & 15.6 & 14.8 & 14.4 \\
\hline Public & 3.0 & -0.7 & 3.7 & 8.1 & 7.2 & 7.7 & 7.9 & 7.9 & 7.9 & 7.8 & 7.4 & 6.1 & 5.4 & 5.0 \\
\hline Private & 14.2 & 9.0 & 8.2 & 6.4 & 10.3 & 10.8 & 10.7 & 10.6 & 10.7 & 10.8 & 9.9 & 9.5 & 9.4 & 9.4 \\
\hline \multicolumn{15}{|l|}{ External sector, public debt, and debt service } \\
\hline Export, f.o.b & 21.3 & 11.0 & 15.6 & 19.7 & 23.7 & 24.0 & 24.4 & 24.5 & 24.6 & 24.6 & 24.0 & 23.5 & 23.0 & 22.8 \\
\hline Imports, c.i.f. & 24.7 & 16.0 & 23.9 & 33.5 & 35.2 & 34.3 & 33.8 & 33.0 & 32.5 & 32.2 & 31.1 & 30.7 & 30.2 & 30.1 \\
\hline Current account balance & & & & & & & & & & & & & & \\
\hline (excluding grants) & -2.0 & -6.1 & -8.6 & -13.2 & -10.1 & -8.6 & -7.8 & -6.8 & -6.3 & -5.8 & -5.2 & -4.8 & -4.7 & -4.8 \\
\hline \multicolumn{15}{|l|}{ Current account balance } \\
\hline (including grants) & -1.3 & -6.0 & -6.0 & -9.2 & -7.8 & -6.3 & -5.7 & -4.9 & -4.3 & -4.0 & -3.8 & -3.8 & -3.8 & -3.9 \\
\hline & \multicolumn{14}{|c|}{ (In units indicated) } \\
\hline Gross official reserves (in millions of SDRs) & 318 & 267 & 285 & 328 & 369 & 421 & 474 & 518 & 565 & 623 & 959 & 1,326 & 1,417 & 1,451 \\
\hline In months of imports of goods & & & & & & & & & & & & & & \\
\hline and nonfactor services & 3 & 4 & 3 & 3 & 3 & 3 & 4 & 4 & 4 & 4 & 5 & 5 & 4 & 4 \\
\hline Exchange rate: Malagasy francs per SDR & & & & & & & & & & & & & & \\
\hline (period average) & 8,391 & 8,774 & 8,646 & $\cdots$ & $\cdots$ & $\cdots$ & $\cdots$ & $\cdots$ & $\cdots$ & $\cdots$ & $\cdots$ & $\cdots$ & $\cdots$ & $\cdots$ \\
\hline Exchange rate: Malagasy francs per U.S. dollar & & & & & & & & & & & & & & \\
\hline (period average) & 6,592 & 6,592 & 6,203 & $\ldots$ & $\ldots$ & $\ldots$ & $\ldots$ & $\ldots$ & $\ldots$ & $\ldots$ & $\ldots$ & $\ldots$ & $\ldots$ & $\ldots$ \\
\hline GDP per capita (in U.S. dollars) & 285 & 278 & 324 & 255 & 254 & 269 & 281 & 295 & 307 & 321 & 396 & 486 & 528 & 550 \\
\hline Nominal GDP (billions of Malagasy francs) & 29,843 & 30,042 & 33,893 & 39,446 & 45,822 & 51,440 & 57,369 & 63,982 & 71,156 & 79,134 & 134,495 & 227,724 & 281,119 & 312,342 \\
\hline
\end{tabular}

Sources: Malagasy authorities; and Fund staff estimates and projections.

1/ Data may not add up due to rounding.

2/ Based on 1993 trade weights.

3/ 2003 includes extrabudgetary expenditure. 
Table 6. Madagascar: Balance of Payments, 2001-23

(In millions of SDRs, unless otherwise indicated)

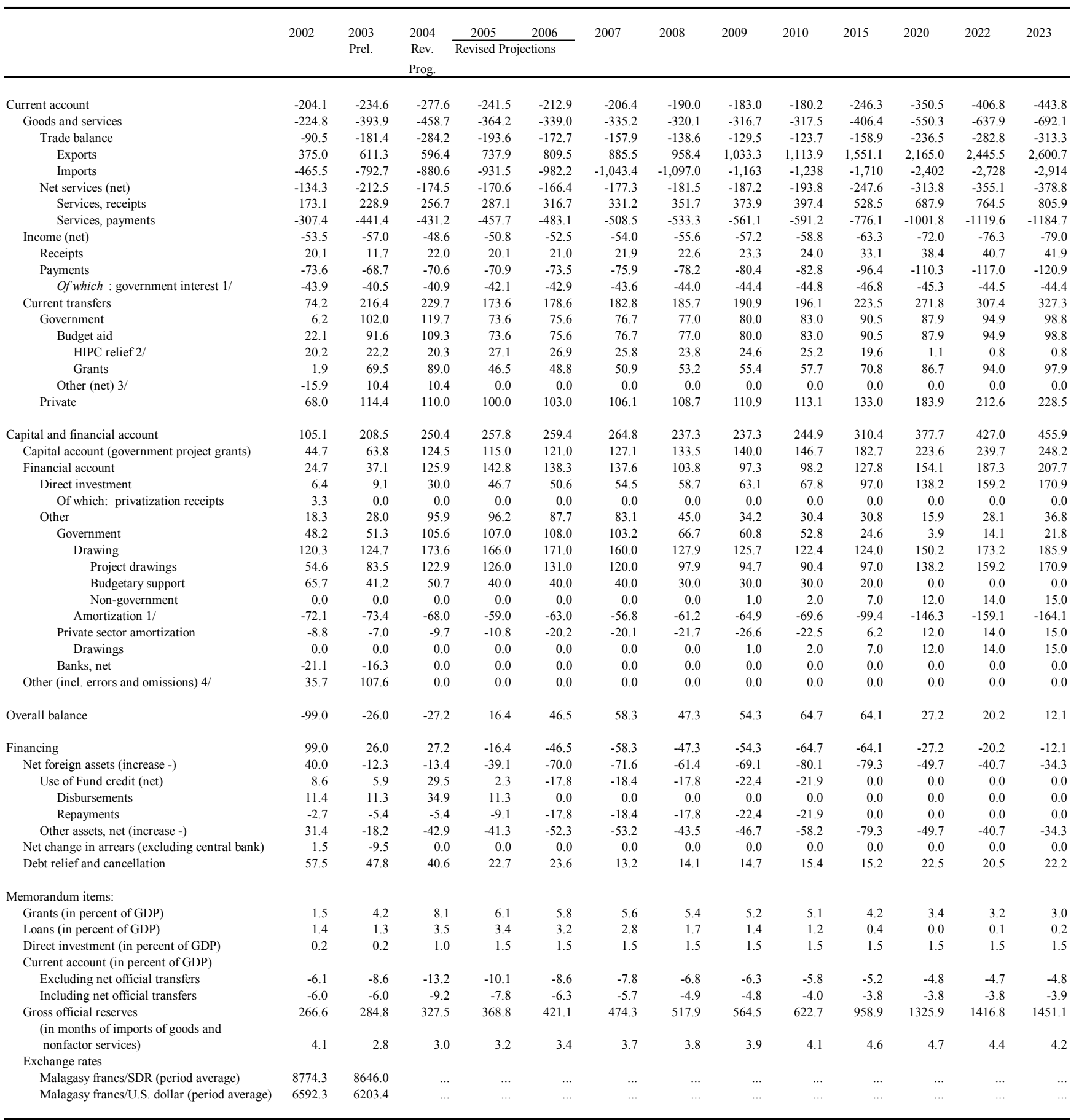

Sources: Central Bank of Madagascar, Ministry of Finance; and Fund staff estimates and projections.

1/ Interest and amortization payments assume Paris Club stock-of-debt reduction will occur at the completion point, envisaged to be in 2004

2/ Interim relief provided by the African Development Bank Group (AfDB), IDA, and the IMF for 2001-03. The distribution of interim relief among these years differs from the original program due to AfDB's choice of a different delivery option than assumed at the time of the decision point.

3/ Other official grants less payments due to scholarships and contributions to international organizations.

4/ Includes commercial credits received or granted. 
Table 7. Madagascar: Nominal and Net Present Value of External Debt Outstanding as of End-December 1999 1/

(in million of U.S. dollars)

\begin{tabular}{|c|c|c|c|c|}
\hline & \multicolumn{2}{|c|}{ Nominal Debt } & \multicolumn{2}{|c|}{$\begin{array}{c}\text { NPV of Debt after Rescheduling } \\
\text { under Naples terms 2/ }\end{array}$} \\
\hline & $\begin{array}{c}\text { From decision } \\
\text { point }\end{array}$ & Revised 3/ & $\begin{array}{l}\text { From decision } \\
\text { point }\end{array}$ & Revised 3/ \\
\hline Total & $4,357.8$ & $3,950.1$ & $2,058.2$ & $2,080.2$ \\
\hline Multilateral & $1,830.1$ & $1,841.7$ & 902.0 & 899.8 \\
\hline IDA & $1,359.8$ & $1,359.8$ & 637.7 & 637.7 \\
\hline IMF & 62.9 & 62.9 & 55.5 & 47.7 \\
\hline African Development Bank & 312.7 & 312.7 & 149.5 & 149.5 \\
\hline Of which: African Development Fund & 288.5 & 288.5 & 123.7 & 123.7 \\
\hline EU & 37.2 & 47.8 & 23.9 & 30.1 \\
\hline BADEA & 7.1 & 4.1 & 6.4 & 3.7 \\
\hline IFAD & 40.0 & 44.0 & 20.5 & 22.3 \\
\hline OPEC Fund & 10.4 & 10.4 & 8.4 & 8.8 \\
\hline Bilateral and Commercial & $2,527.7$ & $2,108.4$ & $1,156.2$ & $1,180.4$ \\
\hline Paris Club & $2,049.3$ & $1,594.3$ & 968.5 & 975.4 \\
\hline Austria & 51.9 & 51.9 & 19.2 & 19.2 \\
\hline Belgium & 43.3 & 43.3 & 18.1 & 18.1 \\
\hline Canada & 22.1 & 22.1 & 15.2 & 15.2 \\
\hline France & 462.2 & 456.8 & 232.3 & 229.0 \\
\hline Germany & 58.6 & 60.9 & 42.8 & 44.1 \\
\hline Israel & 2.1 & 2.1 & 0.8 & 0.8 \\
\hline Italy & 190.6 & 190.6 & 75.4 & 75.4 \\
\hline Japan & 364.1 & 365.9 & 343.2 & 344.6 \\
\hline Russia 4/ & 590.4 & 136.4 & 120.1 & 127.6 \\
\hline Spain & 166.8 & 167.1 & 63.5 & 63.6 \\
\hline Sweden & 8.5 & 8.5 & 6.4 & 6.4 \\
\hline Switzerland & 7.0 & 7.0 & 2.9 & 2.9 \\
\hline United Kingdom & 43.2 & 43.2 & 15.3 & 15.3 \\
\hline United States & 38.4 & 38.4 & 13.1 & 13.1 \\
\hline Non-Paris Club official bilateral & 453.1 & 497.4 & 179.4 & 199.5 \\
\hline Algeria & 95.9 & 115.3 & 31.7 & 38.1 \\
\hline Angola & 3.7 & 3.7 & 1.2 & 1.2 \\
\hline China & 46.6 & 44.0 & 15.6 & 14.1 \\
\hline Iraq & 114.2 & 138.9 & 58.9 & 72.2 \\
\hline Kuwait & 13.6 & 13.6 & 9.4 & 10.4 \\
\hline Libya & 167.4 & 170.3 & 55.3 & 56.3 \\
\hline Saudi Arabia & 9.2 & 9.2 & 5.5 & 5.5 \\
\hline United Arab Emirates & 2.5 & 2.5 & 1.7 & 1.7 \\
\hline Commercial Creditors & 25.3 & 16.7 & 8.4 & 5.5 \\
\hline AGIP & 7.9 & 7.9 & 2.6 & 2.6 \\
\hline ENI International Ltd Bank & 9.8 & 1.7 & 3.2 & 0.6 \\
\hline Hong Kong CITOH Bank & 4.2 & 4.2 & 1.4 & 1.4 \\
\hline London Club Debt & 3.4 & 2.1 & 1.1 & 0.7 \\
\hline IPITRADE 5/ & 0.0 & 0.7 & 0.0 & 0.2 \\
\hline
\end{tabular}

Sources: Malagasy authorities; and Bank-Fund staff estimates.

$1 /$ Public and publicly guaranteed debt only.

2/ Refers to public and publicly guaranteed external debt only and assumes a stock-of-debt operation on Naples terms (67 percent NPV reduction)

by Paris Club creditors, and at least comparable action by other official bilateral and commercial creditors.

3/ Due to updated information through creditors' statements.

4/ The revised data take into account the 1997 Paris Club agreement signed in 2000 and amended in 2001 for post cut-off arrears.

The decision point data are prior to this agreement.

5/ IPITRADE was classified under France in the decision point document. 
Table 8. Madagascar: Estimated Assistance at Decision Point (Amended) 1/

\section{EXPORT CRITERION}

Total HIPC Initiative assistance

based on end-1999 data

NPV of debt-

to-exports-target

150

(In percent) (In millions of US dollars)

Common

reduction factor

at the decision

point 3/

Assistance (decision point document)

Assistance (revised)

\section{4}

836

2,080

900

975

199

6

830

251

Sources: Malagasy authorities and Bank-Fund staff estimates and projections.

1/ Assistance is provided under the principles of proportional burden sharing which is described in "HIPC Initiative - Estimated Costs and Burden Sharing Approaches" (www.imf.org) and (IDA/SECM97-306, 7/7/97).

2/ Includes official bilateral and commercial creditors.

3/ Percentage of NPVof debt reduction required from each creditor to reach the $150 \mathrm{HIPC}$ threshold under the export criterion.

4/ Based on revised data at the decision point after full application of traditional debt relief mechanisms.

5/ Assumes a stock-of-debt operation on Naples terms (67 percent NPV reduction) by Paris Club creditors, and at least comparable action by other official bilateral and commercial creditors at end- 1999 .

6/ Based on the average of three consecutive years of exports of goods and services ending in 1999. 
Table 9. Comparison of Discount Rate and Exchange Rate Assumptions at End-1999 and End-2003

\begin{tabular}{|c|c|c|c|c|}
\hline & \multicolumn{2}{|c|}{$\begin{array}{l}\text { Discount Rates 1/ 2/ } \\
\text { (In percent per annum) }\end{array}$} & \multicolumn{2}{|c|}{$\begin{array}{c}\text { Exchange Rates 2/ } \\
\text { (Currency per U.S. dollar) }\end{array}$} \\
\hline & $\begin{array}{l}\text { At decision } \\
\text { point }\end{array}$ & $\begin{array}{l}\text { At completion } \\
\text { point }\end{array}$ & $\begin{array}{l}\text { At Decision } \\
\text { Point }\end{array}$ & $\begin{array}{l}\text { At Completion } \\
\text { Point }\end{array}$ \\
\hline \multicolumn{5}{|l|}{ Currency } \\
\hline Austrian schilling & 5.47 & 4.63 & 13.70 & 10.92 \\
\hline Belgian franc & 5.47 & 4.63 & 40.16 & 32.02 \\
\hline Canadian dollar & 6.67 & 5.18 & 1.44 & 1.29 \\
\hline Swiss franc & 4.27 & 3.21 & 1.60 & 1.24 \\
\hline Chinese yuan & 5.59 & 4.20 & 8.28 & 8.28 \\
\hline Deutsche mark & 5.47 & 4.63 & 1.95 & 1.55 \\
\hline Danish kroner & 5.32 & 4.77 & 7.40 & 5.91 \\
\hline Domestic currency: Malagasy franc & 5.59 & 4.20 & 6543.20 & 6098.09 \\
\hline European currency unit & 5.47 & 4.63 & 1.00 & 0.79 \\
\hline Spanish peseta & 5.47 & 4.63 & 165.62 & 132.09 \\
\hline Finnish markaa & 5.47 & 4.63 & 5.92 & 4.72 \\
\hline French franc & 5.47 & 4.63 & 6.53 & 5.21 \\
\hline Indian rupee & 5.59 & 4.20 & 43.49 & 45.61 \\
\hline Iraqi dinar & 5.59 & 4.20 & 0.31 & 0.31 \\
\hline Italian lira & 5.47 & 4.63 & 1927.40 & 1537.10 \\
\hline Japanese yen & 1.98 & 1.70 & 102.20 & 107.11 \\
\hline Kuwaiti dinar & 5.59 & 4.20 & 0.30 & 0.29 \\
\hline Netherland guilder & 5.47 & 4.63 & 2.19 & 1.75 \\
\hline Norwegian kroner & 6.64 & 5.30 & 8.04 & 6.67 \\
\hline Portuguese escudo & 5.47 & 4.63 & 199.56 & 159.15 \\
\hline Saudi Arabian rial & 5.59 & 4.20 & 3.75 & 3.75 \\
\hline Special drawing rights & 5.59 & 4.20 & 0.73 & 0.67 \\
\hline Swedish kroner & 5.80 & 5.00 & 8.53 & 7.20 \\
\hline UAE Dirham & 5.59 & 4.20 & 3.67 & 3.66 \\
\hline United Kingdom pound sterling & 6.70 & 5.37 & 0.62 & 0.56 \\
\hline United States dollar & 7.04 & 4.47 & 1.00 & 1.00 \\
\hline $\begin{array}{l}\text { Memorandum item: } \\
\quad \text { Paris Club cut-off-date is July 1, } 1983\end{array}$ & & & & \\
\hline
\end{tabular}

Sources: OECD; and IMF, International Financial Statistics.

1/ The discount rates used are the average commercial interest reference rates (CIRRs) for the respective currencies over the six-month period ending in December 2003 for the completion point and in December 1999 for the decision point.

2/ For all Euro area currencies, the Euro CIRR is used. For the Kuwaiti Dinar, the US dollar CIRR is used for completion point calculations (compared to the decision point calculations, when the SDR CIRR was used), in accordance to the explicit peg of the Dinar to the US dollar in the beginning of 2003. For all other currencies for which the respective CIRRs are not available, the SDR discount rate is used as a proxy. 
Table 10. Madagascar: External Public and Publicly Guaranteed Debt at End-December 2003 1/ (In millions of U.S. dollars, unless otherwise indicated)

\begin{tabular}{|c|c|c|c|c|}
\hline & \multicolumn{2}{|c|}{ Legal Situation } & \multicolumn{2}{|c|}{ NPV of Debt } \\
\hline & Nominal Debt & NPV of Debt & $\begin{array}{c}\text { After Enhanced } \\
\text { HIPC 2/ }\end{array}$ & $\begin{array}{c}\text { After Additional } \\
\text { Bilateral Assistance }\end{array}$ \\
\hline Total & $4,843.0$ & $3,429.2$ & $2,078.6$ & $1,466.9$ \\
\hline Multilateral & $2,634.7$ & $1,613.4$ & $1,231.3$ & $1,231.3$ \\
\hline IDA & $1,981.2$ & $1,165.8$ & 888.3 & 888.3 \\
\hline IMF & 172.2 & 143.7 & 126.2 & 126.2 \\
\hline African Development Bank & 337.8 & 203.5 & 160.0 & 160.0 \\
\hline Of which: African Development Fund & 335.2 & 200.7 & 159.2 & 159.2 \\
\hline $\mathrm{EU}$ & 61.1 & 43.8 & 20.9 & 20.9 \\
\hline BADEA & 10.5 & 9.7 & 7.2 & 7.2 \\
\hline IFAD & 64.3 & 40.0 & 27.8 & 27.8 \\
\hline OPEC Fund & 7.5 & 6.9 & 0.8 & 0.8 \\
\hline Bilateral & $2,208.3$ & $1,815.7$ & 847.3 & 235.6 \\
\hline Paris Club & $1,636.9$ & $1,249.2$ & 656.4 & 45.2 \\
\hline Austria & 57.1 & 28.8 & 11.5 & 0.0 \\
\hline Belgium 3/ & 0.0 & 0.0 & 0.0 & 0.0 \\
\hline Canada & 16.8 & 12.9 & 3.9 & 0.0 \\
\hline France & 491.4 & 280.4 & 156.9 & 5.0 \\
\hline Germany & 36.4 & 43.7 & 22.2 & 0.4 \\
\hline Israel & 2.1 & 1.3 & 0.4 & 0.4 \\
\hline Italy & 160.6 & 99.6 & 38.5 & 0.0 \\
\hline Japan 4/ & 406.3 & 431.0 & 307.9 & 0.0 \\
\hline Russia & 198.9 & 169.9 & 39.5 & 39.5 \\
\hline Spain & 174.4 & 125.6 & 56.5 & 0.0 \\
\hline Sweden & 6.8 & 8.3 & 1.6 & 0.0 \\
\hline Switzerland & 7.9 & 4.7 & 1.6 & 0.0 \\
\hline United Kingdom & 40.3 & 18.9 & 8.2 & 0.0 \\
\hline United States & 37.9 & 24.2 & 7.9 & 0.0 \\
\hline Non-Paris Club official bilateral & 556.8 & 551.9 & 186.6 & 186.6 \\
\hline Algeria & 127.8 & 127.8 & 30.4 & 30.4 \\
\hline Angola & 3.7 & 3.7 & 0.6 & 0.6 \\
\hline China & 34.6 & 32.3 & 15.3 & 15.3 \\
\hline Iraq & 178.7 & 178.7 & 85.4 & 85.4 \\
\hline Kuwait & 8.2 & 8.0 & 2.0 & 2.0 \\
\hline Libya & 192.5 & 192.5 & 48.4 & 48.4 \\
\hline Saudi Arabia & 8.6 & 6.1 & 3.5 & 3.5 \\
\hline United Arab Emirates & 2.7 & 2.7 & 1.1 & 1.1 \\
\hline Commercial creditors & 14.7 & 14.6 & 4.4 & 3.8 \\
\hline AGIP & 11.1 & 11.1 & 2.6 & 2.6 \\
\hline ENI International Ltd Bank & 1.9 & 1.9 & 0.5 & 0.5 \\
\hline Hong Kong CITOH Bank & 0.7 & 0.6 & 1.2 & 0.6 \\
\hline London Club Debt 5/ & 0.0 & 0.0 & 0.0 & 0.0 \\
\hline IPITRADE 6/ & 0.9 & 0.9 & 0.1 & 0.1 \\
\hline
\end{tabular}

Sources: Malagasy authorities; and Bank-Fund staff estimates.

1/ Public and publicly guaranteed debt only.

2/ Assumes full delivery of HIPC assistance at end-2003.

3/ Belgium sold its debt to a private creditor in June 2000.

4/ Assumed Cologne flow implemented.

5/ London Club debt was paid off in May 2002.

6/ IPITRADE was classified under France in the decision point document. 
Table 11. Madagascar: Comparison of Net Present Value of External Public Debt Between Decision Point and Completion Point

(In millions of U.S. dollars; unless otherwise indicated)

\begin{tabular}{|c|c|c|c|c|c|}
\hline & \multicolumn{5}{|c|}{ Stock at end-2003 } \\
\hline & \multicolumn{2}{|c|}{ Decision Point DSA (Projection) 1/ } & \multicolumn{3}{|c|}{ Completion Point DSA 2/ } \\
\hline & $\begin{array}{l}\text { After enhanced } \\
\text { HIPC debt relief }\end{array}$ & & $\begin{array}{l}\text { After traditional } \\
\text { debt relief }\end{array}$ & $\begin{array}{l}\text { After enhanced } \\
\text { HIPC debt relief 3/ }\end{array}$ & $\begin{array}{l}\text { After additional } \\
\text { bilateral relief 4/ }\end{array}$ \\
\hline NPV of debt using end-December 1999 parameters & & 1,519 & 2,488 & 1,720 & 1,144 \\
\hline Multilateral & & 892 & 1,261 & 941 & 941 \\
\hline Official bilateral & & 627 & 1,228 & 779 & 203 \\
\hline NPV of debt using end-December 2003 parameters & & $\ldots$ & 3,053 & 2,079 & 1,467 \\
\hline Multilateral & & $\ldots$ & 1,613 & 1,231 & 1,231 \\
\hline Official bilateral & & $\ldots$ & 1,439 & 847 & 236 \\
\hline \multicolumn{6}{|l|}{ NPV of debt-to-exports ratio 5/ } \\
\hline Using end-December 1999 parameters & & 133 & & & \\
\hline Using end-December 2003 parameters & & $\ldots$ & 284 & 194 & 137 \\
\hline \multicolumn{6}{|l|}{ Exports of goods and services (three-year average) $5 /$} \\
\hline Decision point & & 1141 & $\ldots$ & $\ldots$ & $\ldots$ \\
\hline Completion point & & $\ldots$ & 1074 & 1074 & 1074 \\
\hline
\end{tabular}

Sources: Malagasy authorities; and Bank-Fund staff estimates.

1/ Debt sustainability analysis (DSA) based on stock of debt at the decision point.

2/ Based on stock of debt reconciled as of end-December 2003.

3/ Assuming full (hypothetical) delivery of enhanced HIPC assistance at end-2003

4/ Assuming full (hypothetical) delivery of enhanced HIPC assistance at end-2003, and debt relief beyond HIPC by some Paris Club and commercial creditors on a voluntary basis.

5 / Based on the average of three consecutive years of exports of goods and services ending in the current year. 
Table 12. Madagascar: Net Present Value of External Debt, 2003-23 1/

(In millions of U.S. dollars; unless otherwise indicated)

\begin{tabular}{|c|c|c|c|c|c|c|c|c|c|c|c|c|c|c|}
\hline & 2003 & 2004 & 2005 & 2006 & 2007 & 2008 & 2009 & 2010 & 2015 & 2020 & 2022 & 2023 & $2003-13$ & 2014-23 \\
\hline & Actuals & \multicolumn{11}{|c|}{ Projections } & \multicolumn{2}{|c|}{ Averages } \\
\hline \multicolumn{15}{|l|}{$\begin{array}{l}\text { I. After traditional debt-relief } \\
\text { mechanisms } 2 /\end{array}$} \\
\hline 1. NPV of total debt $(2+6)$ & $3,429.2$ & $3,157.7$ & $3,267.6$ & $3,354.5$ & $3,443.9$ & $3,505.2$ & $3,557.4$ & $3,605.2$ & $3,830.6$ & $3,836.9$ & $3,805.1$ & $3,793.4$ & $3,494.9$ & $3,828.4$ \\
\hline NPV of total debt after full delivery $3 /$ & $3,052.8$ & $3,157.7$ & $3,267.6$ & $3,354.5$ & $3,443.9$ & $3,505.2$ & $3,557.4$ & $3,605.2$ & $3,830.6$ & $3,836.9$ & $3,805.1$ & $3,793.4$ & $3,460.8$ & $3,828.4$ \\
\hline Multilateral & $1,613.4$ & $1,611.7$ & $1,605.8$ & $1,582.6$ & $1,552.3$ & $1,517.1$ & $1,472.4$ & $1,425.9$ & $1,239.9$ & $1,010.7$ & 894.6 & 833.6 & $1,493.3$ & $1,074.4$ \\
\hline Bilateral & $1,439.3$ & $1,408.2$ & $1,378.9$ & $1,348.6$ & $1,333.2$ & $1,316.8$ & $1,300.5$ & $1,285.7$ & $1,246.6$ & $1,110.4$ & $1,023.1$ & 970.3 & $1,331.2$ & $1,144.0$ \\
\hline 2. NPV of outstanding debt $(3+4)$ & $3,429.2$ & $3,019.9$ & $2,984.7$ & $2,931.2$ & $2,885.5$ & $2,833.9$ & $2,772.9$ & $2,711.6$ & $2,486.5$ & $2,121.1$ & $1,917.7$ & $1,803.9$ & $2,858.6$ & $2,218.5$ \\
\hline 3. Official bilateral and commercial & $1,815.7$ & $1,408.2$ & $1,378.9$ & $1,348.6$ & $1,333.2$ & $1,316.8$ & $1,300.5$ & $1,285.7$ & $1,246.6$ & $1,110.4$ & $1,023.1$ & 970.3 & $1,365.3$ & $1,144.0$ \\
\hline Paris Club & $1,249.2$ & $1,151.8$ & $1,122.3$ & $1,092.0$ & $1,076.7$ & $1,060.8$ & $1,045.2$ & $1,030.9$ & 996.3 & 877.3 & 808.3 & 767.2 & $1,081.8$ & 908.8 \\
\hline Other official bilateral and commercial & 566.5 & 256.4 & 256.6 & 256.6 & 256.5 & 255.9 & 255.4 & 254.8 & 250.3 & 233.1 & 214.8 & 203.1 & 283.5 & 235.3 \\
\hline 4. Multilateral & $1,613.4$ & $1,611.7$ & $1,605.8$ & $1,582.6$ & $1,552.3$ & $1,517.1$ & $1,472.4$ & $1,425.9$ & $1,239.9$ & $1,010.7$ & 894.6 & 833.6 & $1,493.3$ & $1,074.4$ \\
\hline IDA & $1,165.8$ & $1,173.5$ & $1,179.1$ & $1,181.1$ & $1,178.5$ & $1,170.7$ & $1,158.8$ & $1,142.5$ & $1,016.2$ & 829.4 & 731.6 & 680.0 & $1,149.1$ & 880.7 \\
\hline IMF & 143.7 & 140.8 & 133.9 & 113.8 & 91.9 & 69.9 & 43.7 & 20.6 & 0.0 & 0.0 & 0.0 & 0.0 & 70.1 & 0.0 \\
\hline African Development Bank & 203.5 & 201.4 & 201.1 & 200.7 & 199.8 & 198.5 & 195.9 & 192.8 & 173.2 & 146.8 & 133.6 & 126.8 & 195.6 & 154.3 \\
\hline Others & 100.4 & 96.0 & 91.7 & 87.0 & 82.1 & 78.0 & 74.0 & 70.0 & 50.5 & 34.5 & 29.3 & 26.8 & 78.5 & 39.5 \\
\hline 5. Nominal stock of total debt & $4,841.6$ & $4,448.1$ & $4,621.4$ & $4,763.6$ & $4,905.2$ & $5,025.2$ & $5,089.3$ & $5,149.0$ & $5,375.3$ & $5,335.2$ & $5,301.3$ & $5,293.5$ & $4,967.0$ & $5,347.9$ \\
\hline \multicolumn{15}{|l|}{ II. After enhanced HIPC assistance } \\
\hline 1. NPV of total debt $(2+6)$ & $3,370.7$ & $2,248.1$ & $2,388.1$ & $2,513.2$ & $2,625.2$ & $2,708.3$ & $2,785.6$ & $2,861.6$ & $3,179.1$ & $3,333.5$ & $3,328.4$ & $3,332.2$ & $2,771.8$ & $3,273.4$ \\
\hline NPV of total debt after full delivery 3 / & $2,078.6$ & $2,248.1$ & $2,388.1$ & $2,513.2$ & $2,625.2$ & $2,708.3$ & $2,785.6$ & $2,861.6$ & $3,179.1$ & $3,333.5$ & $3,328.4$ & $3,332.2$ & $2,654.3$ & $3,273.4$ \\
\hline Multilateral & $1,231.3$ & $1,381.5$ & $1,539.6$ & $1,682.3$ & $1,811.6$ & $1,911.7$ & $2,004.6$ & $2,093.7$ & $2,471.2$ & $2,719.1$ & $2,776.4$ & $2,818.4$ & $1,855.7$ & $2,637.3$ \\
\hline Bilateral & 847.3 & 866.6 & 848.4 & 831.0 & 813.7 & 796.7 & 781.0 & 767.9 & 707.9 & 614.4 & 552.0 & 513.7 & 798.6 & 636.1 \\
\hline 2. NPV of outstanding debt $(3+4)$ & $3,370.7$ & $2,110.2$ & $2,105.2$ & $2,089.9$ & $2,066.9$ & $2,037.0$ & $2,001.1$ & $1,967.9$ & $1,834.9$ & $1,617.6$ & $1,441.0$ & $1,342.7$ & $2,135.6$ & $1,663.5$ \\
\hline 3. Official bilateral and commercial & $1,796.3$ & 866.6 & 848.4 & 831.0 & 813.7 & 796.7 & 781.0 & 767.9 & 707.9 & 614.4 & 552.0 & 513.7 & 884.9 & 636.1 \\
\hline Paris Club & $1,226.3$ & 670.5 & 652.4 & 635.2 & 618.3 & 601.6 & 586.3 & 573.6 & 517.0 & 436.4 & 387.6 & 358.0 & 656.0 & 456.5 \\
\hline Other official bilateral and commercial & 569.9 & 196.1 & 196.1 & 195.7 & 195.4 & 195.1 & 194.7 & 194.3 & 190.9 & 178.0 & 164.4 & 155.7 & 228.9 & 179.7 \\
\hline 4. Multilateral & $1,574.4$ & $1,243.6$ & $1,256.7$ & $1,259.0$ & $1,253.2$ & $1,240.3$ & $1,220.1$ & $1,200.1$ & $1,127.0$ & $1,003.2$ & 889.0 & 829.0 & $1,250.7$ & $1,027.4$ \\
\hline IDA & $1,152.1$ & 901.6 & 914.6 & 925.8 & 934.7 & 940.5 & 943.6 & 943.5 & 915.8 & 829.4 & 731.6 & 680.0 & 951.0 & 842.6 \\
\hline IMF & 142.1 & 125.6 & 121.3 & 109.4 & 91.9 & 69.9 & 43.7 & 20.6 & 0.0 & 0.0 & 0.0 & 0.0 & 67.0 & 0.0 \\
\hline African Develop & 196.9 & 163.1 & 166.8 & 170.7 & 174.6 & 178.6 & 182.0 & 185.7 & 173.2 & 146.8 & 133.6 & 126.8 & 179.6 & 154.3 \\
\hline Others & 83.2 & 53.3 & 54.0 & 53.1 & 52.1 & 51.4 & 50.8 & 50.2 & 38.1 & 27.1 & 23.8 & 22.2 & 53.1 & 30.5 \\
\hline 5. Nominal stock of total debt & $4,437.6$ & $3,088.4$ & $3,315.5$ & $3,518.3$ & $3,704.1$ & $3,867.2$ & $3,977.4$ & $4,086.0$ & $4,505.9$ & $4,702.6$ & $4,729.3$ & $4,753.1$ & $3,892.5$ & $4,637.0$ \\
\hline \multicolumn{15}{|l|}{$\begin{array}{l}\text { III. After bilateral debt relief beyond } \\
\text { HIPC assistance } 4 /\end{array}$} \\
\hline 1. NPV of total debt $(2+6)$ & $3,344.7$ & $1,618.2$ & $1,776.3$ & $1,918.5$ & $2,047.4$ & $2,147.1$ & $2,239.5$ & $2,328.2$ & $2,699.8$ & $2,926.8$ & $2,964.7$ & $2,994.5$ & $2,261.4$ & $2,848.5$ \\
\hline NPV of total & $1,466.9$ & $1,618.2$ & $1,776.3$ & $1,918.5$ & $2,047.4$ & $2,147.1$ & $2,239.5$ & $2,328.2$ & $2,699.8$ & $2,926.8$ & $2,964.7$ & $2,994.5$ & $2,090.7$ & $2,848.5$ \\
\hline Multilateral & $1,231.3$ & $1,381.5$ & $1,539.6$ & $1,682.3$ & $1,811.6$ & $1,911.7$ & $2,004.6$ & $2,093.7$ & $2,471.2$ & $2,719.1$ & $2,776.4$ & $2,818.4$ & $1,855.7$ & $2,637.3$ \\
\hline Bilateral & 235.6 & 236.8 & 236.7 & 236.3 & 235.8 & 235.4 & 234.9 & 234.5 & 228.7 & 207.7 & 188.3 & 176.1 & 235.0 & 211.2 \\
\hline 2. NPV of outstanding debt $(3+4)$ & $3,344.7$ & $1,480.4$ & $1,493.4$ & $1,495.3$ & $1,489.1$ & $1,475.7$ & $1,455.1$ & $1,434.5$ & $1,355.7$ & $1,210.9$ & $1,077.3$ & $1,005.1$ & $1,625.2$ & $1,238.6$ \\
\hline 3. Official bilateral and commercial & $1,770.3$ & 236.8 & 236.7 & 236.3 & 235.8 & 235.4 & 234.9 & 234.5 & 228.7 & 207.7 & 188.3 & 176.1 & 374.5 & 211.2 \\
\hline Paris Club & $1,203.8$ & 41.5 & 41.4 & 41.4 & 41.4 & 41.4 & 41.4 & 41.4 & 39.0 & 30.6 & 24.7 & 21.0 & 146.9 & 32.5 \\
\hline Other official bilateral and commercial & 566.5 & 195.3 & 195.3 & 194.9 & 194.4 & 194.0 & 193.6 & 193.1 & 189.7 & 177.1 & 163.6 & 155.1 & 227.6 & 178.7 \\
\hline 4. Multilateral & $1,574.4$ & $1,243.6$ & $1,256.7$ & $1,259.0$ & $1,253.2$ & $1,240.3$ & $1,220.1$ & $1,200.1$ & $1,127.0$ & $1,003.2$ & 889.0 & 829.0 & $1,250.7$ & $1,027.4$ \\
\hline 5. Nominal stock of total debt & $4,403.4$ & $2,449.0$ & $2,693.5$ & $2,913.3$ & $3,116.2$ & $3,296.1$ & $3,421.8$ & $3,543.3$ & $4,019.5$ & $4,290.6$ & $4,361.1$ & $4,411.3$ & $3,372.8$ & $4,206.2$ \\
\hline \multicolumn{15}{|l|}{ Memorandum items: } \\
\hline 6. NPV of new borrowing & $\ldots$ & 137.8 & 282.9 & 423.3 & 558.3 & 671.3 & 784.4 & 893.6 & $1,344.1$ & $1,715.9$ & $1,887.4$ & $1,989.5$ & 699.8 & $1,609.9$ \\
\hline Official bilateral & $\ldots$ & 0.0 & 0.0 & 0.0 & 0.0 & 0.0 & 0.0 & 0.0 & 0.0 & 0.0 & 0.0 & 0.0 & 0.0 & 0.0 \\
\hline Multilateral & $\ldots$ & 137.8 & 282.9 & 423.3 & 558.3 & 671.3 & 784.4 & 893.6 & $1,344.1$ & $1,715.9$ & $1,887.4$ & $1,989.5$ & 699.8 & $1,609.9$ \\
\hline
\end{tabular}

Sources: Malagasy authorities; and Bank-Fund staff estimates and projections.

1/ Discounted on the basis of the 6-month average commercial interest reference rate for the respective currency, ending in December 2003.

2/ Refers to public and publicly guaranteed external debt only and assumes a stock-of-debt operation on Naples terms (67 percent NPV reduction) by Paris Club creditors, and at least comparable action by other official bilateral and commercial creditors.

3/ Assumes the entire HIPC Initiative assistance is fully delivered as of end-2003.

4/ Includes additional debt relief provided on a voluntary basis by the Paris Club and commercial creditors beyond the requirements of the enhanced HIPC framework. 
Table 13. Madagascar: External Debt Service After Full Implementation of Debt-Relief Mechanisms, 2004-24 (In millions of U.S. dollars; unless otherwise indicated)

\begin{tabular}{|c|c|c|c|c|c|c|c|c|c|c|c|c|c|}
\hline & 2004 & 2005 & 2006 & 2007 & 2008 & 2009 & 2010 & 2015 & 2020 & 2022 & 2023 & $2004-13$ & $2014-23$ \\
\hline Total debt service & 167.4 & 160.3 & 180.7 & 173.9 & 180.4 & 189.8 & 193.2 & 215.4 & 282.4 & 300.1 & 307.2 & 181.2 & 259.5 \\
\hline After traditional debt-relief mechanisms 1/ & 164.5 & 154.2 & 171.4 & 161.6 & 165.7 & 172.8 & 170.6 & 150.4 & 176.1 & 182.0 & 187.7 & 160.4 & 167.4 \\
\hline Multilateral & 69.0 & 73.0 & 90.2 & 96.2 & 99.9 & 107.9 & 107.8 & 89.8 & 97.1 & 98.6 & 98.3 & 93.2 & 94.5 \\
\hline IDA & 41.6 & 43.9 & 47.8 & 52.5 & 57.5 & 61.3 & 65.2 & 72.6 & 80.8 & 82.6 & 82.4 & 58.2 & 78.0 \\
\hline IMF & 8.9 & 12.9 & 25.8 & 26.6 & 25.9 & 29.1 & 24.9 & 0.0 & 0.0 & 0.0 & 0.0 & 17.6 & 0.0 \\
\hline African Development Bank & 9.6 & 7.8 & 7.9 & 8.3 & 8.8 & 10.0 & 10.4 & 11.2 & 12.0 & 12.1 & 12.0 & 9.5 & 11.7 \\
\hline Others & 8.9 & 8.5 & 8.8 & 8.8 & 7.7 & 7.4 & 7.3 & 6.0 & 4.3 & 3.9 & 3.8 & 7.8 & 4.9 \\
\hline Official bilateral & 95.5 & 81.2 & 81.2 & 65.3 & 65.8 & 64.9 & 62.8 & 60.6 & 79.0 & 83.4 & 89.4 & 67.2 & 72.9 \\
\hline Paris Club & 91.9 & 70.4 & 70.1 & 54.3 & 54.2 & 53.3 & 51.2 & 48.7 & 63.7 & 64.3 & 69.0 & 56.6 & 57.9 \\
\hline Of which: ODA & 37.2 & 30.4 & 29.8 & 15.7 & 15.2 & 13.7 & 10.9 & 11.9 & 11.0 & 11.8 & 12.2 & 18.3 & 11.7 \\
\hline Other official bilateral and commercial & 3.5 & 10.8 & 11.1 & 11.1 & 11.6 & 11.6 & 11.6 & 11.9 & 15.2 & 19.2 & 20.4 & 10.6 & 15.0 \\
\hline Total debt service & 59.6 & 92.4 & 105.9 & 116.3 & 124.8 & 132.1 & 133.6 & 164.4 & 247.5 & 268.7 & 273.4 & 119.8 & 213.5 \\
\hline After enhanced HIPC assistance & 56.7 & 86.3 & 96.6 & 104.0 & 110.1 & 115.0 & 111.0 & 99.4 & 141.3 & 150.6 & 153.8 & 98.9 & 121.4 \\
\hline Multilateral & 38.1 & 38.5 & 50.0 & 58.2 & 65.1 & 71.8 & 70.8 & 61.1 & 95.4 & 97.3 & 97.0 & 58.8 & 76.7 \\
\hline IDA & 24.2 & 25.1 & 27.4 & 30.1 & 33.6 & 36.6 & 39.8 & 45.8 & 80.0 & 82.6 & 82.4 & 35.0 & 61.5 \\
\hline IMF & 6.0 & 9.6 & 17.0 & 22.1 & 25.9 & 29.1 & 24.9 & 0.0 & 0.0 & 0.0 & 0.0 & 15.7 & 0.0 \\
\hline African Development Bank & 2.8 & 2.3 & 2.3 & 2.5 & 2.5 & 3.2 & 3.2 & 11.2 & 12.0 & 12.1 & 12.0 & 4.4 & 11.7 \\
\hline Others & 5.1 & 1.6 & 3.4 & 3.5 & 3.0 & 2.9 & 2.9 & 4.1 & 3.4 & 2.6 & 2.6 & 3.7 & 3.6 \\
\hline Official bilateral & 18.6 & 47.8 & 46.6 & 45.9 & 45.1 & 43.2 & 40.2 & 38.3 & 45.9 & 53.3 & 56.8 & 40.2 & 44.7 \\
\hline Paris Club & 15.1 & 39.5 & 38.0 & 37.3 & 36.4 & 34.6 & 31.6 & 29.3 & 34.3 & 38.6 & 41.3 & 32.1 & 33.3 \\
\hline Of which: ODA & 5.9 & 9.8 & 9.2 & 8.6 & 8.0 & 7.4 & 7.0 & 5.7 & 5.0 & 4.8 & 4.7 & 7.5 & 5.2 \\
\hline Other official bilateral and commercial & 3.4 & 8.3 & 8.6 & 8.6 & 8.6 & 8.6 & 8.6 & 9.0 & 11.6 & 14.6 & 15.6 & 8.1 & 11.5 \\
\hline Total debt service & 50.3 & 54.8 & 69.9 & 81.0 & 90.3 & 99.4 & 104.0 & 137.7 & 217.0 & 234.4 & 236.8 & 90.0 & 183.6 \\
\hline After bilateral debt relief beyond HIPC 2/ & 47.4 & 48.8 & 60.6 & 68.7 & 75.6 & 82.4 & 81.4 & 72.7 & 110.7 & 116.3 & 117.2 & 69.2 & 91.6 \\
\hline Multilateral & 38.1 & 38.5 & 50.0 & 58.2 & 65.1 & 71.8 & 70.8 & 61.1 & 95.4 & 97.3 & 97.0 & 58.8 & 76.7 \\
\hline Official bilateral & 9.3 & 10.2 & 10.6 & 10.6 & 10.5 & 10.5 & 10.5 & 11.6 & 15.3 & 18.9 & 20.2 & 10.5 & 14.9 \\
\hline Paris Club & 5.8 & 1.9 & 1.9 & 1.9 & 1.9 & 1.9 & 1.9 & 2.6 & 3.8 & 4.4 & 4.8 & 2.3 & 3.5 \\
\hline Of which: ODA & 5.6 & 0.0 & 0.0 & 0.0 & 0.0 & 0.0 & 0.0 & 0.0 & 0.0 & 0.0 & 0.0 & 0.6 & 0.0 \\
\hline Other official bilateral and commercial & 3.5 & 8.4 & 8.7 & 8.7 & 8.7 & 8.7 & 8.7 & 9.0 & 11.5 & 14.5 & 15.4 & 8.1 & 11.4 \\
\hline \multicolumn{14}{|l|}{ Memorandum items: } \\
\hline Debt service of new debt & 2.9 & 6.1 & 9.3 & 12.3 & 14.7 & 17.0 & 22.6 & 65.0 & 106.3 & 118.1 & 119.6 & 20.8 & 92.0 \\
\hline Multilateral & 2.9 & 6.1 & 9.3 & 12.3 & 14.7 & 17.0 & 22.6 & 65.0 & 106.3 & 118.1 & 119.6 & 20.8 & 92.0 \\
\hline Official bilateral & 0.0 & 0.0 & 0.0 & 0.0 & 0.0 & 0.0 & 0.0 & 0.0 & 0.0 & 0.0 & 0.0 & 0.0 & 0.0 \\
\hline \multicolumn{14}{|l|}{ Nominal HIPC relief } \\
\hline Under the enhanced HIPC initiative & 107.8 & 67.9 & 74.8 & 57.5 & 55.6 & 57.7 & 59.6 & 51.0 & 34.8 & 31.4 & 33.8 & 61.5 & 45.1 \\
\hline
\end{tabular}

Sources: Malagasy authorities; and Bank-Fund staff estimates and projections.

1/ Assumes a stock-of-debt operation on Naples terms (67 percent NPV reduction) by Paris Club creditors, and at least comparable action by other bilateral and commercial crreditors.

2/ Includes additional debt relief provided on a voluntary basis by the Paris Club and commercial creditors beyond the requirements of the enhanced HIPC . framework. 
Table 14. Madagascar: External Debt Indicators, 2003-23 1/

(In percent, unless otherwise indicated)

\begin{tabular}{|c|c|c|c|c|c|c|c|c|c|c|c|c|c|c|}
\hline & 2003 & 2004 & 2005 & 2006 & 2007 & 2008 & 2009 & 2010 & 2015 & 2020 & 2022 & 2023 & \multicolumn{2}{|c|}{$2003-2012 \quad 2013-2023$} \\
\hline & Actuals & \multicolumn{11}{|c|}{ Projections } & \multicolumn{2}{|c|}{ Averages } \\
\hline \multicolumn{15}{|c|}{ After traditional debt relief mechanisms $2 /$} \\
\hline NPV of debt-to-GDP ratio & 62.7 & 71.1 & 71.7 & 67.7 & 64.4 & 60.8 & 57.4 & 54.1 & 40.2 & 28.3 & 24.3 & 22.6 & 60.9 & 33.2 \\
\hline NPV of debt-to-exports ratio 3 / & 284.3 & 299.9 & 249.3 & 228.1 & 208.8 & 195.6 & 184.2 & 173.6 & 133.2 & 97.0 & 85.2 & 80.1 & 214.4 & 112.0 \\
\hline NPV of debt-to-revenue ratio 4/ & 598.2 & 627.3 & 631.2 & 583.4 & 536.5 & 493.4 & 453.9 & 420.0 & 283.5 & 190.6 & 164.1 & 152.4 & 509.3 & 230.5 \\
\hline Debt service-to-exports ratio & $\ldots$ & 13.3 & 10.7 & 10.9 & 9.7 & 9.3 & 9.2 & 8.7 & 7.0 & 6.7 & 6.3 & 6.1 & 9.7 & 6.8 \\
\hline Debt service-to-revenue ratio 4/ & $\ldots$ & 33.3 & 31.0 & 31.4 & 27.1 & 25.4 & 24.2 & 22.5 & 15.9 & 14.0 & 12.9 & 12.3 & 25.8 & 14.7 \\
\hline \multicolumn{15}{|l|}{ After enhanced HIPC assistance } \\
\hline NPV of debt-to-GDP ratio & 61.7 & 50.6 & 52.4 & 50.7 & 49.1 & 46.9 & 44.9 & 43.0 & 33.4 & 24.6 & 21.3 & 19.8 & 47.9 & 28.1 \\
\hline NPV of debt-to-exports ratio 3/ & 314.0 & 213.5 & 182.2 & 170.9 & 159.1 & 151.1 & 144.2 & 137.8 & 110.5 & 84.3 & 74.5 & 70.3 & 173.1 & 94.9 \\
\hline $\begin{array}{l}\text { NPV of debt-to-exports ratio } \\
\text { (existing debt only) }\end{array}$ & 314.0 & 200.4 & 160.6 & 142.1 & 125.3 & 113.7 & 103.6 & 94.8 & 63.8 & 40.9 & 32.3 & 28.3 & 142.2 & 50.3 \\
\hline \multicolumn{15}{|l|}{ NPV of debt-to-exports ratio } \\
\hline after full delivery in 2003 3/ 5/ & 193.6 & 213.5 & 182.2 & 170.9 & 159.1 & 151.1 & 144.2 & 137.8 & 110.5 & 84.3 & 74.5 & 70.3 & 161.0 & 94.9 \\
\hline NPV of debt-to-revenue ratio 4/ & 588.2 & 446.6 & 461.3 & 437.1 & 409.0 & 381.2 & 355.4 & 333.4 & 235.2 & 165.6 & 143.5 & 133.9 & 401.5 & 195.0 \\
\hline Debt service-to-exports ratio & $\ldots$ & 4.7 & 6.2 & 6.4 & 6.5 & 6.5 & 6.4 & 6.0 & 5.4 & 5.9 & 5.7 & 5.4 & 6.0 & 5.5 \\
\hline Debt service-to-revenue ratio 4/ & $\ldots$ & 11.8 & 17.9 & 18.4 & 18.1 & 17.6 & 16.8 & 15.6 & 12.2 & 12.3 & 11.6 & 11.0 & 16.1 & 11.9 \\
\hline \multicolumn{15}{|l|}{$\begin{array}{l}\text { After bilateral debt relief beyond HIPC } \\
\text { assistance } 6 /\end{array}$} \\
\hline NPV of debt-to-GDP ratio & 61.2 & 36.4 & 39.0 & 38.7 & 38.3 & 37.2 & 36.1 & 35.0 & 28.3 & 21.6 & 19.0 & 17.8 & 38.8 & 24.3 \\
\hline NPV of debt-to-exports ratio 3/ & 311.5 & 153.7 & 135.5 & 130.4 & 124.1 & 119.8 & 115.9 & 112.1 & 93.9 & 74.0 & 66.4 & 63.2 & 141.6 & 82.0 \\
\hline NPV of debt-to-exports ratio & & & & & & & & & & & & & & \\
\hline (existing debt only) & 311.5 & 140.6 & 113.9 & 101.7 & 90.3 & 82.3 & 75.3 & 69.1 & 47.1 & 30.6 & 24.1 & 21.2 & 110.8 & 37.4 \\
\hline \multicolumn{15}{|l|}{ NPV of debt-to-exports ratio a } \\
\hline fter full delivery in 2003 3/ 5/ & 136.6 & 153.7 & 135.5 & 130.4 & 124.1 & 119.8 & 115.9 & 112.1 & 93.9 & 74.0 & 66.4 & 63.2 & 124.1 & 82.0 \\
\hline NPV of debt-to-revenue ratio 4/ & 583.7 & 321.5 & 343.1 & 333.7 & 319.0 & 302.2 & 285.7 & 271.2 & 199.8 & 145.4 & 127.8 & 120.3 & 325.8 & 168.2 \\
\hline Debt service-to-exports ratio & $\ldots$ & 4.8 & 4.2 & 4.7 & 4.9 & 5.0 & 5.1 & 5.0 & 4.8 & 5.5 & 5.2 & 5.0 & 4.8 & 5.0 \\
\hline Debt service-to-revenue ratio 4/ & $\ldots$ & 10.0 & 10.6 & 12.1 & 12.6 & 12.7 & 12.7 & 12.1 & 10.2 & 10.8 & 10.1 & 9.5 & 11.7 & 10.2 \\
\hline \multicolumn{15}{|l|}{$\begin{array}{l}\text { Memorandum items (in millions of } \\
\text { U.S. dollars): }\end{array}$} \\
\hline \multicolumn{15}{|l|}{ NPV of debt after enhanced } \\
\hline HIPC assistance & $3,370.7$ & $2,248.1$ & $2,388.1$ & $2,513.2$ & $2,625.2$ & $2,708.3$ & $2,785.6$ & $2,861.6$ & $3,179.1$ & $3,333.5$ & $3,328.4$ & $3,332.2$ & $2,742.8$ & $3,254.2$ \\
\hline Of which: existing debt only & $3,370.7$ & $2,110.2$ & $2,105.2$ & $2,089.9$ & $2,066.9$ & $2,037.0$ & $2,001.1$ & $1,967.9$ & $1,834.9$ & $1,617.6$ & $1,441.0$ & $1,342.7$ & $2,160.5$ & $1,683.8$ \\
\hline \multicolumn{15}{|l|}{ Debt service after enhanced } \\
\hline HIPC assistance & $\ldots$ & 59.6 & 92.4 & 105.9 & 116.3 & 124.8 & 132.1 & 133.6 & 164.4 & 247.5 & 268.7 & 273.4 & 116.2 & 207.8 \\
\hline GDP & $5,466.0$ & $4,443.2$ & $4,559.1$ & $4,957.6$ & $5,350.8$ & $5,769.1$ & $6,199.6$ & $6,660.9$ & $9,527.4$ & $13,576.1$ & $15,642.1$ & $16,790.2$ & $5,825.2$ & $12,080.0$ \\
\hline Exports of goods and services 3 / & $1,174.8$ & $1,254.6$ & $1,502.5$ & $1,655.2$ & $1,791.4$ & $1,930.1$ & $2,073.6$ & $2,227.0$ & $3,064.3$ & $4,203.9$ & $4,730.0$ & $5,019.8$ & $1,850.8$ & $3,769.1$ \\
\hline Exports of goods and services & & & & & & & & & & & & & & \\
\hline (three-year mvg. Avg.) 3/ & $1,073.6$ & $1,052.9$ & $1,310.6$ & $1,470.8$ & $1,649.7$ & $1,792.2$ & $1,931.7$ & $2,076.9$ & $2,876.5$ & $3,955.4$ & $4,464.9$ & $4,737.0$ & $1,695.8$ & $3,547.0$ \\
\hline Government Revenue 4/ & 573.1 & 503.4 & 517.7 & 575.0 & 641.9 & 710.4 & 783.8 & 858.4 & $1,351.4$ & $2,012.7$ & $2,318.9$ & $2,489.1$ & 713.3 & $1,762.9$ \\
\hline
\end{tabular}

Sources: Malagasy authorities; and Bank-Fund staff estimates and projections.

1/ All debt indicators refer to public and publicly guaranteed (PPG) debt and are defined after rescheduling, unless otherwise indicated.

2/ Assumes a stock-of-debt operation on Naples terms (67 percent NPV reduction) by Paris Club creditors, and at least comparable action by other bilateral and commercial creditors.

3/ Based on the average of three consecutive years of exports of goods and services ending in the current year. (e.g., export average over 2001-2003 for NPV of debt-to-exports ratio in 2003).

4/ Revenue is defined as central government revenue, excluding grants.

5/ Assuming full delivery of HIPC assistance at end-2003.

6/ Includes additional debt relief provided on a voluntary basis by the Paris Club and commercial creditors beyond the requirements of the enhanced HIPC framework. 
Table 15. Madagascar: Sensitivity Analysis, 2003-22 1/

(In percent; unless otherwise indicated)

\begin{tabular}{|c|c|c|c|c|c|c|c|c|c|c|c|c|c|c|}
\hline & 2003 & 2004 & 2005 & 2006 & 2007 & 2008 & 2009 & 2010 & 2015 & 2020 & 2022 & 2023 & $2003-13$ & $2014-23$ \\
\hline & \multicolumn{12}{|c|}{ Projections } & \multicolumn{2}{|c|}{ Averages } \\
\hline \multicolumn{15}{|l|}{ Baseline scenario } \\
\hline NPV of debt-to-exports ratio $2 /$ & 193.6 & 213.5 & 182.2 & 170.9 & 159.1 & 151.1 & 144.2 & 137.8 & 110.5 & 84.3 & 74.5 & 70.3 & 157.4 & 92.3 \\
\hline NPV of debt-to-GDP ratio & $\ldots$ & 50.6 & 52.4 & 50.7 & 49.1 & 46.9 & 44.9 & 43.0 & 33.4 & 24.6 & 21.3 & 19.8 & 45.5 & 27.3 \\
\hline Debt service-to-exports ratio $2 /$ & $\ldots$ & 4.7 & 6.2 & 6.4 & 6.5 & 6.5 & 6.4 & 6.0 & 5.4 & 5.9 & 5.7 & 5.4 & 6.0 & 5.5 \\
\hline Debt service-to-revenue ratio 3 / & $\ldots$ & 11.8 & 17.9 & 18.4 & 18.1 & 17.6 & 16.8 & 15.6 & 12.2 & 12.3 & 11.6 & 11.0 & 15.8 & 11.7 \\
\hline \multicolumn{15}{|l|}{ Memorandum items (in millions of U.S. dollars): } \\
\hline NPV of debt & $2,078.6$ & $2,248.1$ & $2,388.1$ & $2,513.2$ & $2,625.2$ & $2,708.3$ & $2,785.6$ & $2,861.6$ & $3,179.1$ & $3,333.5$ & $3,328.4$ & $3,332.2$ & 2654.3 & 3273.4 \\
\hline Of which: new debt & $\ldots$ & 137.8 & 282.9 & 423.3 & 558.3 & 671.3 & 784.4 & 893.6 & $1,344.1$ & $1,715.9$ & $1,887.4$ & $1,989.5$ & 699.8 & 1609.9 \\
\hline Debt service & $\ldots$ & 59.6 & 92.4 & 105.9 & 116.3 & 124.8 & 132.1 & 133.6 & 164.4 & 247.5 & 268.7 & 273.4 & 119.8 & 213.5 \\
\hline Of which: new debt & $\ldots$ & 2.9 & 6.1 & 9.3 & 12.3 & 14.7 & 17.0 & 22.6 & 65.0 & 106.3 & 118.1 & 119.6 & 20.8 & 92.0 \\
\hline Exports of goods and services, three-year average & $1,073.6$ & $1,052.9$ & $1,310.6$ & $1,470.8$ & $1,649.7$ & $1,792.2$ & $1,931.7$ & $2,076.9$ & $2,876.5$ & $3,955.4$ & $4,464.9$ & $4,737.0$ & 1771.7 & 3648.6 \\
\hline Exports of goods and services, annual & $1,174.8$ & $1,254.6$ & $1,502.5$ & $1,655.2$ & $1,791.4$ & $1,930.1$ & $2,073.6$ & $2,227.0$ & $3,064.3$ & $4,203.9$ & $4,730.0$ & $5,019.8$ & 1927.3 & 3876.7 \\
\hline GDP & $5,466.0$ & $4,443.2$ & $4,559.1$ & $4,957.6$ & $5,350.8$ & $5,769.1$ & $6,199.6$ & $6,660.9$ & $9,527.4$ & $13,576.1$ & $15,642.1$ & $16,790.2$ & 6046.6 & 12461.9 \\
\hline Revenues & 573.1 & 503.4 & 517.7 & 575.0 & 641.9 & 710.4 & 783.8 & 858.4 & $1,351.4$ & $2,012.7$ & $2,318.9$ & $2,489.1$ & 750.9 & 1826.4 \\
\hline \multicolumn{15}{|l|}{ Sensivity analysis } \\
\hline \multicolumn{15}{|l|}{ Alternative scenario I 4/ } \\
\hline NPV of debt-to-exports ratio $2 /$ & $\ldots$ & 213.5 & 186.1 & 178.2 & 170.4 & 164.2 & 159.1 & 153.9 & 130.5 & 103.4 & 91.1 & 85.5 & 165.8 & 111.3 \\
\hline NPV of debt-to-GDP ratio & $\ldots$ & 50.6 & 53.3 & 53.4 & 53.1 & 52.1 & 51.1 & 49.9 & 43.4 & 34.9 & 30.9 & 29.1 & 50.6 & 37.3 \\
\hline Debt service-to-exports ratio 2/ & $\ldots$ & 4.7 & 6.5 & 6.9 & 7.1 & 7.2 & 7.2 & 6.9 & 6.6 & 7.6 & 7.5 & 7.2 & 6.7 & 7.0 \\
\hline \multicolumn{15}{|l|}{ Memorandum items (in millions of U.S. dollars): } \\
\hline NPV of debt & $\ldots$ & $2,248.0$ & $2,380.6$ & $2,489.9$ & $2,585.6$ & $2,654.9$ & $2,716.4$ & $2,775.2$ & $2,999.8$ & $2,998.5$ & $2,902.4$ & $2,852.5$ & $2,648.1$ & $2,978.6$ \\
\hline Of which: new debt & $\ldots$ & 137.8 & 275.4 & 400.0 & 518.7 & 617.9 & 715.3 & 807.3 & $1,164.9$ & $1,380.9$ & $1,461.5$ & $1,509.7$ & 636.1 & $1,315.1$ \\
\hline Debt service & $\ldots$ & 59.5 & 92.2 & 105.3 & 115.4 & 123.6 & 130.5 & 131.7 & 157.9 & 232.1 & 248.7 & 251.1 & 118.1 & 200.5 \\
\hline Of which: new debt & $\ldots$ & 2.9 & 5.9 & 8.7 & 11.4 & 13.4 & 15.4 & 20.6 & 58.5 & 90.9 & 98.1 & 97.2 & 19.2 & 79.0 \\
\hline Exports of goods and services, three-year average & $1,073.6$ & $1,053.0$ & $1,279.2$ & $1,397.1$ & $1,517.5$ & $1,617.1$ & $1,707.7$ & $1,803.0$ & $2,299.4$ & $2,899.9$ & $3,184.6$ & $3,338.0$ & $1,585.6$ & $2,729.7$ \\
\hline Exports of goods and services, annual & $1,174.8$ & $1,254.6$ & $1,408.3$ & $1,528.4$ & $1,615.9$ & $1,707.2$ & $1,800.0$ & $1,901.8$ & $2,407.1$ & $3,036.3$ & $3,335.4$ & $3,496.6$ & $1,697.8$ & $2,858.0$ \\
\hline GDP & $5,466.0$ & $4,443.2$ & $4,465.1$ & $4,664.7$ & $4,873.2$ & $5,091.0$ & $5,318.6$ & $5,556.3$ & $6,913.9$ & $8,603.2$ & $9,389.4$ & $9,809.0$ & $5,280.1$ & $8,120.8$ \\
\hline \multicolumn{15}{|l|}{ Alternative scenario II 5/ } \\
\hline NPV of debt-to-exports ratio $2 /$ & $\ldots$ & 213.8 & 193.1 & 190.9 & 177.5 & 163.9 & 152.6 & 145.8 & 116.2 & 87.6 & 77.1 & 72.7 & 163.8 & 96.4 \\
\hline NPV of debt-to-GDP ratio & $\ldots$ & 50.6 & 53.7 & 53.3 & 51.8 & 49.6 & 47.4 & 45.3 & 35.0 & 25.4 & 21.9 & 20.4 & 47.5 & 28.4 \\
\hline Debt service-to-exports ratio 2/ & $\ldots$ & 4.8 & 6.8 & 7.2 & 6.7 & 6.7 & 6.6 & 6.2 & 5.7 & 6.2 & 6.0 & 5.6 & 6.3 & 5.8 \\
\hline \multicolumn{15}{|l|}{ Memorandum items: (in millions of U.S. dollars): } \\
\hline NPV of debt & $\ldots$ & $2,248.1$ & $2,449.5$ & $2,643.0$ & $2,773.9$ & $2,860.1$ & $2,940.7$ & $3,020.2$ & $3,332.7$ & $3,453.6$ & $3,433.3$ & $3,432.4$ & $2,841.0$ & $3,403.5$ \\
\hline Of which: new debt & $\ldots$ & 137.8 & 344.3 & 553.1 & 707.0 & 823.2 & 939.6 & $1,052.3$ & $1,497.8$ & $1,836.0$ & $1,992.3$ & $2,089.7$ & 828.9 & $1,740.0$ \\
\hline Debt service & $\ldots$ & 59.6 & 93.9 & 109.0 & 119.8 & 128.3 & 135.5 & 137.1 & 174.8 & 260.7 & 281.4 & 282.8 & 123.6 & 225.6 \\
\hline Of which: new debt & $\ldots$ & 2.9 & 7.5 & 12.4 & 15.7 & 18.2 & 20.5 & 26.1 & 75.4 & 119.4 & 130.8 & 129.0 & 24.6 & 104.1 \\
\hline Exports of goods and services, three-year average & $1,073.6$ & $1,051.6$ & $1,268.4$ & $1,384.3$ & $1,562.6$ & $1,745.4$ & $1,926.8$ & $2,071.5$ & $2,867.3$ & $3,943.8$ & $4,452.3$ & $4,723.8$ & $1,744.7$ & $3,637.7$ \\
\hline Exports of goods and services, annual & $1,174.8$ & $1,250.5$ & $1,379.8$ & $1,522.5$ & $1,785.6$ & $1,928.1$ & $2,066.7$ & $2,219.7$ & $3,054.9$ & $4,192.5$ & $4,717.7$ & $5,007.0$ & $1,899.5$ & $3,865.9$ \\
\hline GDP & $5,466.0$ & $4,443.2$ & $4,559.1$ & $4,957.6$ & $5,350.8$ & $5,769.1$ & $6,199.6$ & $6,660.9$ & $9,527.4$ & $13,576.1$ & $15,642.1$ & $16,790.2$ & $6,046.6$ & $12,461.9$ \\
\hline \multicolumn{15}{|l|}{ Alternative scenario III 6/ } \\
\hline NPV of debt-to-exports ratio $2 /$ & $\ldots$ & 213.5 & 184.9 & 175.7 & 165.7 & 159.2 & 153.7 & 148.5 & 126.5 & 103.4 & 94.0 & 89.8 & 162.0 & 110.3 \\
\hline NPV of debt-to-GDP ratio & $\ldots$ & 50.6 & 53.2 & 52.1 & 51.1 & 49.5 & 47.9 & 46.3 & 38.2 & 30.1 & 26.8 & 25.3 & 48.0 & 32.6 \\
\hline Debt service-to-exports ratio 2/ & $\ldots$ & 4.7 & 6.2 & 6.5 & 6.6 & 6.6 & 6.6 & 6.2 & 5.9 & 6.8 & 6.7 & 6.4 & 6.2 & 6.3 \\
\hline \multicolumn{15}{|l|}{ Memorandum items: (in millions of U.S. dollars): } \\
\hline NPV of debt & $\ldots$ & $2,248.1$ & $2,423.2$ & $2,584.3$ & $2,733.1$ & $2,853.7$ & $2,969.4$ & $3,084.7$ & $3,639.9$ & $4,090.3$ & $4,195.5$ & $4,252.9$ & $2,884.0$ & $3,939.8$ \\
\hline Of which: new debt & $\ldots$ & 137.8 & 318.0 & 494.3 & 666.2 & 816.7 & 968.3 & $1,116.8$ & $1,805.0$ & $2,472.7$ & $2,754.5$ & $2,910.2$ & 872.0 & $2,276.3$ \\
\hline Debt service & $\ldots$ & 59.6 & 93.3 & 107.6 & 118.9 & 128.2 & 136.3 & 138.7 & 181.6 & 285.3 & 315.1 & 322.9 & 124.2 & 245.1 \\
\hline Of which: new debt & & 2.9 & 6.9 & 11.0 & 14.8 & 18.1 & 21.2 & 27.7 & 82.2 & 144.1 & 164.6 & 169.0 & 25.3 & 123.6 \\
\hline Exports of goods and services, three-year average & $1,073.6$ & $1,052.9$ & $1,310.6$ & $1,470.8$ & $1,649.7$ & $1,792.2$ & $1,931.7$ & $2,076.9$ & $2,876.5$ & $3,955.4$ & $4,464.9$ & $4,737.0$ & $1,771.7$ & $3,648.6$ \\
\hline Exports of goods and services, annual & $1,174.8$ & $1,254.6$ & $1,502.5$ & $1,655.2$ & $1,791.4$ & $1,930.1$ & $2,073.6$ & $2,227.0$ & $3,064.3$ & $4,203.9$ & $4,730.0$ & $5,019.8$ & $1,927.3$ & $3,876.7$ \\
\hline GDP & $5,466.0$ & $4,443.2$ & $4,559.1$ & $4,957.6$ & $5,350.8$ & $5,769.1$ & $6,199.6$ & $6,660.9$ & $9,527.4$ & $13,576.1$ & $15,642.1$ & $16,790.2$ & $6,046.6$ & $12,461.9$ \\
\hline
\end{tabular}

Sources: Malagasy authorities; and Bank-Fund staff estimates and projections.

1/ All debt indicators refer to public and publicly guaranteed debt and assistance under the HIPC Initiative and debt relief beyond HIPC Initiative assistance are assumed to be fully delivered at end-2003.

2/ Exports of goods and services as defined in IMF, Balance of Payments Manual, 5th edition, 1993 and excludes transit trade. The NPV of debt-to-exports ratio is based on the average of three consecutive years of exports of goods and services ending in the current year; the debt-service ratio is base on the current export year.

3 / Revenues are defined as central government revenues, excluding grants.

4/ Scenario I assumes an average 4 per cent GDP growth rate over the medium term

5/ Scenario II assumes a 50 percent reduction in the price of Madagascar's two main export commodities.

6/ Scenario III assumes a change in the composition of external financing, with a reduction in grants equivalent to 1 percentage point of GDP. 
Table 16 Madagascar: Status of Creditor Participation Under Enhanced HIPC Initiative

\begin{tabular}{|c|c|c|c|c|c|c|}
\hline & \multirow[b]{2}{*}{$\begin{array}{l}\text { Debt Relief } \\
\text { in NPV Terms } \\
\text { (US\$ mil.) } 1 / \\
\end{array}$} & \multirow[b]{2}{*}{$\begin{array}{c}\text { Percentage } \\
\text { of Total } \\
\text { Assistance }\end{array}$} & \multirow[b]{2}{*}{$\begin{array}{l}\text { Satisfactory } \\
\text { Reply }\end{array}$} & \multirow[b]{2}{*}{$\begin{array}{l}\text { Modalities To } \\
\text { Deliver Debt Relief }\end{array}$} & \multicolumn{2}{|c|}{ Revised assistance 1/ } \\
\hline & & & & & $\begin{array}{c}\text { Debt relief } \\
\text { in NPV terms } \\
\text { (US\$ millions) }\end{array}$ & $\begin{array}{c}\text { Percentage } \\
\text { of total } \\
\text { assistance }\end{array}$ \\
\hline IDA & 252.2 & 31.0 & Yes & $\begin{array}{l}\text { IDA assistance is being provided over a period of } 19 \text { years (2001-2020). Interim } \\
\text { assistance has been provided equivalent to a } 50 \% \text { reduction on Madagascar's debts } \\
\text { service to IDA on debt disbursed and outstanding as of end-December 1999. After } \\
\text { Completion Point, assistance will be provided in the same manner, adjusting the } \\
\text { percentage of debt service reduction to } 51 \text { percent in order to achieve the revised } \\
\text { total assistance. IDA will be providing a cumulative nominal assistance of } \\
\text { US\$444.4 million in nominal terms. }\end{array}$ & 256.2 & 30.7 \\
\hline IMF & 22.0 & 2.7 & Yes & $\begin{array}{l}\text { IMF assistance will be delivered through grants from the PRGF/HIPC Trust to an } \\
\text { Umbrella Account. These resources, plus accrued interest, would be used to reduce } \\
\text { the payments falling due to IMF during } 2001-2008 \text { on Madagascar's obligations. } \\
\text { Total nominal debt service savings are expected to amount SDR } 18.2 \text { million in } \\
\text { NPV, of which SDR } 5.7 \text { million was provided as interim assistance through } \\
\text { September } 2004 \text {. }\end{array}$ & 19.2 & 2.3 \\
\hline AfDB & 59.1 & 7.3 & Yes & $\begin{array}{l}\text { Assistance will be delivered through a reduction of } 80 \text { percent of the debt service } \\
\text { payments falling due to the AfDB Group until full debt relief is provided. Interim } \\
\text { relief of US } \$ 32.0 \text { million has been provided as of October, } 2004 \text {. }\end{array}$ & 60.1 & 7.2 \\
\hline IFAD & 8.1 & 1.0 & Yes & $\begin{array}{l}\text { Assistance will be delivered at the completion point, through a reduction of debt } \\
\text { service payments on eligible debt by up to } 100 \text { percent until the target in NPV } \\
\text { terms is reached. Preliminary estimates show that IFAD's relief could be delivered } \\
\text { over } 7 \text { years. }\end{array}$ & 8.9 & 1.1 \\
\hline OPEC Fund & 3.3 & 0.4 & Yes & $\begin{array}{l}\text { Full assistance will be provided through concessional loans, which will be used to } \\
\text { meet the payments to the OPEC Fund until the resources are exhausted. }\end{array}$ & 3.5 & 0.4 \\
\hline BADEA & 2.5 & 0.3 & Yes & $\begin{array}{l}\text { Has agreed in principle to participate in the initiative, but still has to agree on } \\
\text { specific delivery modalities for Madagascar }\end{array}$ & 1.5 & 0.2 \\
\hline $\mathrm{EU}$ & 9.5 & 1.2 & Yes & $\begin{array}{l}\text { Debt-service relief on selected EU loans during the interim period, supplemented } \\
\text { with grants to pay off EU loans at the completion point. As of end-October } 2004 \text {, } \\
\text { approximately US } \$ 2.3 \text { million of interim assistance has been provided. }\end{array}$ & 12.1 & 1.4 \\
\hline$\underline{\text { Total Multilateral }}$ & 356.7 & 43.8 & & & 361.5 & 43.3 \\
\hline Paris Club Creditors & 382.9 & 47.1 & Yes & $\begin{array}{l}\text { Interim assistance is being provided through Cologne flow rescheduling and some } \\
\text { creditors have cancelled } 100 \% \text { of flow during the interim period. The Paris Club } \\
\text { creditors will deliver the rest of the relief at the completion point. Japan is in the } \\
\text { process of implementing the Cologne flow rescheduling which has been agreed in } \\
\text { principle. Belgium sold its debt to a commercial creditor in June } 2000 \text {. }\end{array}$ & 391.9 & 46.9 \\
\hline Non Paris Club Creditors & 70.9 & 8.7 & & & 80.1 & 9.6 \\
\hline Algeria & 12.5 & 1.5 & No & & 15.3 & 1.8 \\
\hline Angola & 0.5 & 0.1 & No & & 0.5 & 0.1 \\
\hline China & 6.2 & 0.8 & Partial & Partial cancellation of loans agreed in November 2001. & 5.7 & 0.7 \\
\hline Iraq & 23.3 & 2.9 & No & & 29.0 & 3.5 \\
\hline & & & & Some debt relief has been provided through a 1999 debt rescheduling. & & \\
\hline Kuwait & 3.7 & 0.5 & Partial & & 4.2 & 0.5 \\
\hline Libya & 21.9 & 2.7 & No & & 22.6 & 2.7 \\
\hline & & & & Some debt relief has been provided through a 2001 debt rescheduling. & & \\
\hline Saudi Arabia & 2.2 & 0.3 & Partial & & 2.2 & 0.3 \\
\hline United Arab Emirates & 0.7 & 0.1 & No & & 0.7 & 0.1 \\
\hline Commercial Creditors & 3.3 & 0.4 & & & 2.2 & 0.3 \\
\hline AGIP & 1.0 & 0.1 & No & & 1.0 & 0.1 \\
\hline ENI International Ltd Bank & 1.3 & 0.2 & No & & 0.2 & 0.0 \\
\hline & & & & HIPC debt relief has been provided through a 2001 debt rescheduling. & & \\
\hline Hong Kong CITOH Bank & 0.6 & 0.1 & Yes & & 0.6 & 0.1 \\
\hline London Club Debt & 0.4 & 0.1 & No & Debt settled without any relief. & 0.3 & 0.0 \\
\hline IPITRADE $1 /$ & 0.0 & 0.0 & $\mathrm{~N} / \mathrm{A}$ & & 0.1 & 0.0 \\
\hline Total Bilateral and Commercial & 457.2 & 56.2 & & & 474.2 & 56.7 \\
\hline TOTAL & 813.8 & 100.0 & & & 835.7 & 100.0 \\
\hline
\end{tabular}

Source: Malagasy authorities and Bank-Fund staff estimates 
Table 17: Madagascar: Delivery of IDA Assistance Under the Enhanced HIPC Initiative, 2000-20 1/

(In millions of U.S. dollars, unless otherwise indicated)

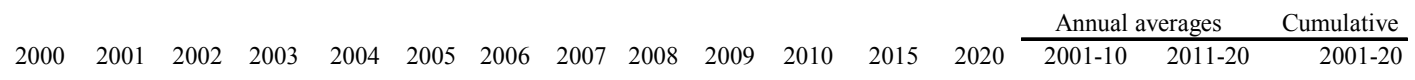

\begin{tabular}{|c|c|c|c|c|c|c|c|c|c|c|c|c|c|c|c|c|}
\hline \multicolumn{17}{|l|}{ Debt service to IDA before } \\
\hline HIPC Assistance & 27.6 & 30.0 & 31.1 & 32.9 & 34.8 & 36.8 & 39.9 & 43.7 & 46.7 & 48.4 & 49.6 & 52.5 & 53.6 & 39.4 & 52.9 & 922.6 \\
\hline Of which: principal & 17.5 & 20.0 & 21.2 & 23.2 & 25.2 & 27.5 & 30.8 & 34.8 & 38.0 & 40.0 & 41.6 & 46.1 & 49.0 & 30.2 & 46.7 & 769.2 \\
\hline Of which: interest & 10.2 & 10.0 & 9.9 & 9.7 & 9.5 & 9.3 & 9.1 & 8.9 & 8.6 & 8.3 & 8.0 & 6.4 & 4.6 & 9.2 & 6.2 & 153.4 \\
\hline \multicolumn{17}{|l|}{ Debt Service after HIPC } \\
\hline Assistance & 27.6 & 14.9 & 15.5 & 16.4 & 17.3 & 18.4 & 19.9 & 21.8 & 23.3 & 24.1 & 24.7 & 26.1 & 52.7 & 19.6 & 29.0 & 485.9 \\
\hline \multicolumn{17}{|l|}{ Savings on debt service to } \\
\hline IDA after revision & 0.0 & 15.0 & 15.6 & 16.5 & 17.4 & 18.5 & 20.0 & 21.9 & 23.4 & 24.3 & 24.9 & 26.3 & 0.8 & 19.8 & 23.9 & 436.7 \\
\hline \multicolumn{17}{|l|}{ Debt Service after revised } \\
\hline HIPC Assistance 2/ & 27.6 & 14.9 & 15.5 & 16.4 & 17.3 & 18.0 & 19.5 & 21.3 & 22.8 & 23.6 & 24.2 & 25.6 & 52.7 & 19.4 & 28.5 & 478.1 \\
\hline \multicolumn{17}{|l|}{ Savings on debt service to } \\
\hline IDA after revision & 0.0 & 15.0 & 15.6 & 16.5 & 17.4 & 18.9 & 20.4 & 22.4 & 23.9 & 24.8 & 25.4 & 26.9 & 0.9 & 20.0 & 24.4 & 444.4 \\
\hline \multicolumn{17}{|l|}{ Savings as percent of debt } \\
\hline service due & 0 & 50 & 50 & 50 & 50 & 51 & 51 & 51 & 51 & 51 & 51 & 51 & 2 & 51 & 46 & 48 \\
\hline
\end{tabular}

Source: IDA staff estimates.

1/ Debt service corresponds to prorated projections based on the disbursed and outstanding debt as of end-1999, converted into U.S. dollars using end-1999 exchange rates.

2/ Subject to Board approval. 
Table 18. Madagascar: Delivery of IMF Assistance under the HIPC Initiative 1/ (In millions of SDRs, unless otherwise indicated)

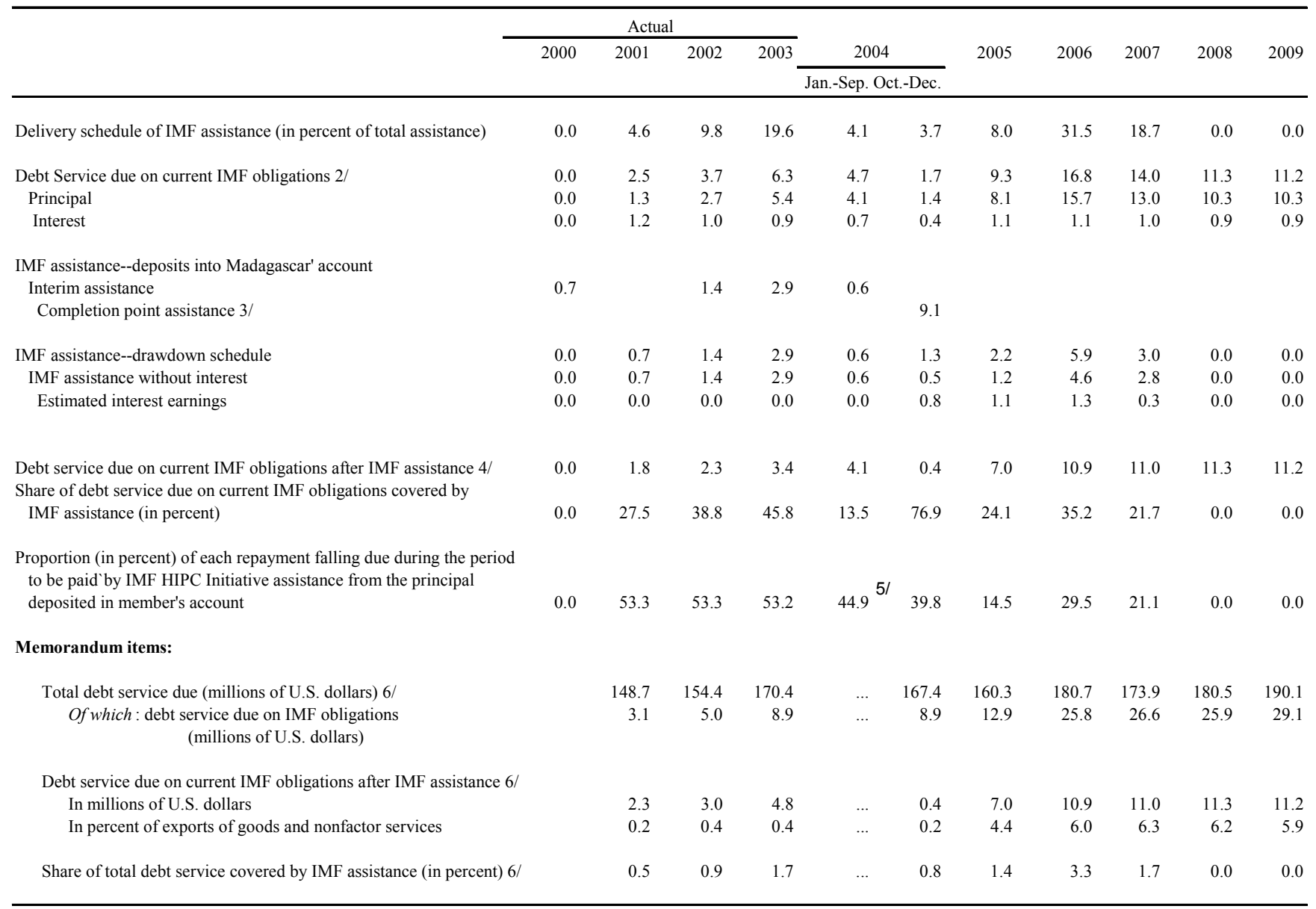

Source: Member authorities; and Fund staff estimates.

1/ Total IMF assistance under the HIPC Initiative is SDR 14.73 million calculated on the basis of data available at the decision point, excluding interest earned on member's account and on committed but undisbursed amounts as described in footnote 4. The amount of IMF assistance committed at decision point is revised from SDR 16.6 million to SDR 14.73 million owing to data revisions. to the 1999 year-end stock of debt.

2/ Forthcoming obligations estimated based on rates and principal schedules in effect at decision point in December 2000. Interest obligations include net SDR charges and assessments.

3/ A final disbursement of SDR 9.111 million (plus accrued interest) assumed to be deposited into Madagascar's account at the completion point in October 2004.

4/ Includes estimated interest earnings on: (1) amounts held in member's account; and (2), up to the completion point, amounts committed but not yet disbursed. It is assumed that these amounts earn a rate of return of 5 percent in SDR terms; actual interest earnings may be higher or lower. Interest accrued on (1) during a calendar year will be used toward the first repayment obligation(s) falling due in the following calendar year except in the final year, when it will be used toward payment of the final obligation(s) falling due in that year. Interest accrued on (2) during the interim period will be used toward the repayment of obligations falling due during the three years after the completion point.

5/ This proportion was not applied to two principal repayment obligations falling due in March and September 2004, as no interim HIPC assistance was approved at the time of repayment.

6/ After traditional debt relief mechanisms. 2004 represents the amount for the whole year . 
Table 19. Madagascar: HIPC Initiative: Status of Country Cases Considered Under the Initiative, end-Sep 2004

\begin{tabular}{|c|c|c|c|c|c|c|c|c|c|c|c|}
\hline \multirow[b]{3}{*}{ Country } & \multirow{3}{*}{$\begin{array}{r}\text { Decision } \\
\text { Point }\end{array}$} & \multirow{3}{*}{$\begin{array}{r}\text { Completion } \\
\text { Point }\end{array}$} & \multicolumn{2}{|c|}{$\begin{array}{c}\text { Target } \\
\text { NPV of Debt-to- } \\
\end{array}$} & \multirow{2}{*}{\multicolumn{5}{|c|}{$\begin{array}{c}\text { Assistance Levels 1/ } \\
\text { (In millions of U.S. dollars, present value) }\end{array}$}} & \multirow{2}{*}{\multicolumn{2}{|c|}{$\begin{array}{l}\text { Estimated Total } \\
\text { Percentage Nominal Debt } \\
\text { Reduction Service Relief } \\
\text { in NPV of (In millions of }\end{array}$}} \\
\hline & & & \multirow{2}{*}{ Exports } & \multirow{2}{*}{$\begin{array}{l}\text { Gov. } \\
\text { revenue } \\
\text { cent) }\end{array}$} & & & & & & & \\
\hline & & & & & Total & Bilateral & $\begin{array}{l}\text { Multi- } \\
\text { lateral }\end{array}$ & IMF & $\begin{array}{r}\text { World } \\
\text { Bank }\end{array}$ & & \\
\hline \multicolumn{12}{|c|}{ Completion point reached under enhanced framework } \\
\hline Benin & Jul. 00 & Mar. 03 & 150 & & 265 & 77 & 189 & 24 & 84 & 31 & 460 \\
\hline Bolivia & & & & & 1,302 & 425 & 876 & 84 & 194 & & 2,060 \\
\hline original framework & Sep. 97 & Sep. 98 & 225 & & 448 & 157 & 291 & 29 & 54 & 14 & 760 \\
\hline enhanced framework & Feb. 00 & Jun. 01 & 150 & & 854 & 268 & 585 & 55 & 140 & 30 & 1,300 \\
\hline Burkina Faso & & & & & 553 & 83 & 469 & 57 & 231 & & 930 \\
\hline original framework & Sep. 97 & Jul. 00 & 205 & & 229 & 32 & 196 & 22 & 91 & 27 & 400 \\
\hline enhanced framework & Jul. 00 & Apr. 02 & 150 & & 195 & 35 & 161 & 22 & 79 & 30 & 300 \\
\hline topping-up & $\ldots$ & Apr. 02 & 150 & & 129 & 16 & 112 & 14 & 61 & 24 & 230 \\
\hline Ethiopia & & & & & 1,982 & 637 & 1,315 & 60 & 832 & & 3,275 \\
\hline original framework & Nov. 01 & Apr. 04 & 150 & & 1,275 & 482 & 763 & 34 & 463 & 47 & 1,941 \\
\hline topping-up & & Apr. 04 & 150 & & 707 & 155 & 552 & 26 & 369 & 31 & 1,334 \\
\hline Ghana & Feb. 02 & Jun. 04 & 69 & 250 & 2,186 & 1,084 & 1,102 & 112 & 782 & 56 & 3,486 \\
\hline Guyana & & & & & 591 & 223 & 367 & 75 & 68 & & 877 \\
\hline original framework & Dec. 97 & May 99 & 107 & 280 & 256 & 91 & 165 & 35 & 27 & 24 & 440 \\
\hline enhanced framework & Nov. 00 & Dec-03 & 150 & 250 & 335 & 132 & 202 & 40 & 41 & 40 & 437 \\
\hline Mali & & & & & 539 & 169 & 370 & 59 & 185 & & 895 \\
\hline original framework & Sep. 98 & Sep. 00 & 200 & & 121 & 37 & 84 & 14 & 43 & 9 & 220 \\
\hline enhanced framework & Sep. 00 & Mar. 03 & 150 & & 417 & 132 & 285 & 45 & 143 & 29 & 675 \\
\hline Mauritania & Feb. 00 & Jun. 02 & 137 & 250 & 622 & 261 & 361 & 47 & 100 & 50 & 1,100 \\
\hline Mozambique & & & & & 2,023 & 1,270 & 753 & 143 & 443 & & 4,300 \\
\hline original framework & Apr. 98 & Jun. 99 & 200 & & 1,717 & 1,076 & 641 & 125 & 381 & 63 & 3,700 \\
\hline enhanced framework & Apr. 00 & Sep. 01 & 150 & & 306 & 194 & 112 & 18 & 62 & 27 & 600 \\
\hline Nicaragua & Dec. 00 & Jan-04 & 150 & & 3,308 & 2,175 & 1,134 & 82 & 191 & 73 & 4500 \\
\hline Niger & & & & & 664 & 234 & 428 & 42 & 240 & & 1,190 \\
\hline original framework & Dec. 00 & Apr. 04 & 150 & & 521 & 211 & 309 & 28 & 170 & 54 & 944 \\
\hline topping-up & & Apr. 04 & 150 & & 143 & 23 & 119 & 14 & 70 & 25 & 246 \\
\hline Senegal & Jun. 00 & Apr. 04 & 133 & 250 & 488 & 212 & 276 & 45 & 124 & 19 & 850 \\
\hline Tanzania & Apr. 00 & Nov. 01 & 150 & & 2,026 & 1,006 & 1,020 & 120 & 695 & 54 & 3,000 \\
\hline Uganda & & & & & 1,003 & 183 & 820 & 160 & 517 & & 1,950 \\
\hline original framework & Apr. 97 & Apr. 98 & 202 & & 347 & 73 & 274 & 69 & 160 & 20 & 650 \\
\hline enhanced framework & Feb. 00 & May 00 & 150 & & 656 & 110 & 546 & 91 & 357 & 37 & 1,300 \\
\hline \multicolumn{12}{|c|}{ Decision point reached under enhanced framework } \\
\hline Cameroon & Oct. 00 & Floating & 150 & & 1,260 & 874 & 324 & 37 & 179 & 27 & 2,000 \\
\hline Chad & May. 01 & Floating & 150 & & 170 & 35 & 134 & 18 & 68 & 30 & 260 \\
\hline Congo, Democratic Rep. of & Jul. 03 & Floating & 150 & & 6,311 & 3,837 & 2,474 & 472 & 831 & 80 & 10,389 \\
\hline Gambia, The & Dec. 00 & Floating & 150 & & 67 & 17 & 49 & 2 & 22 & 27 & 90 \\
\hline Guinea & Dec. 00 & Floating & 150 & & 545 & 215 & 328 & 31 & 152 & 32 & 800 \\
\hline Guinea-Bissau & Dec. 00 & Floating & 150 & & 416 & 212 & 204 & 12 & 93 & 85 & 790 \\
\hline Honduras & Jul. 00 & Floating & 110 & 250 & 556 & 215 & 340 & 30 & 98 & 18 & 900 \\
\hline Madagascar & Dec. 00 & Floating & 150 & & 814 & 457 & 357 & 22 & 252 & 40 & 1,500 \\
\hline Malawi & Dec. 00 & Floating & 150 & & 643 & 163 & 480 & 30 & 331 & 44 & 1,000 \\
\hline Rwanda & Dec. 00 & Floating & 150 & & 452 & 56 & 397 & 44 & 228 & 71 & 800 \\
\hline São Tomé and Príncipe & Dec. 00 & Floating & 150 & & 97 & 29 & 68 & - & 24 & 83 & 200 \\
\hline Sierra Leone & Mar. 02 & Floating & 150 & & 600 & 205 & 354 & 123 & 122 & 80 & 950 \\
\hline Zambia & Dec. 00 & Floating & 150 & & 2,499 & 1,168 & 1,331 & 602 & 493 & 63 & 3,850 \\
\hline \multicolumn{12}{|l|}{ Preliminary HIPC document issued } \\
\hline Côte d'Ivoire & Mar. 983 & $\ldots$ & 141 & 280 & 345 & 163 & 182 & 23 & 91 & 64 & 800 \\
\hline Total assistance provided/com & & & & & 32,325 & 15,686 & 16,503 & $\mathbf{2 , 5 5 7} 5$ & 7,669 & & 53,203 \\
\hline Preliminary HIPC document iss & & & & & & & & & & & \\
\hline Côte d'Ivoire 6/ & $\ldots$ & $\ldots$ & 91 & 250 & 2,569 & 1,027 & 918 & 166 & 438 & 37 & 3,900 \\
\hline
\end{tabular}

Sources: IMF and World Bank Board decisions, completion point documents, decision point documents, preliminary HIPC documents, and staff calculations.

1/ Assistance levels are at countries' respective decision or completion points, as applicable.

2/ In percent of the net present value of debt at the decision or completion point (as applicable), after the full use of traditional debt-relief mechanisms.

3/ Côte d'Ivoire reached its decision point under the original framework in March 1998. The total amount of assistance committed thereunder was

US\$345 million in NPV terms.

4/ Nonreschedulable debt to non-Paris Club official bilateral creditors and the London Club, which was already subject to a highly concessional restructuring,

is excluded from the NPVof debt at the completion point in the calculation of this ratio.

5/ Equivalent to SDR 1,721 million at an SDR/USD exchange rate of 0.6730, as of December 1, 2003.

6/ It is suggested that enhanced HIPC relief for Côte d'Ivoire overtake the commitments made under the original HIPC framework. 
Table 20. Madagascar: Paris Club Creditors' Delivery of Debt Relief Under Bilateral Initiatives Beyond the HIPC Initiative 1/

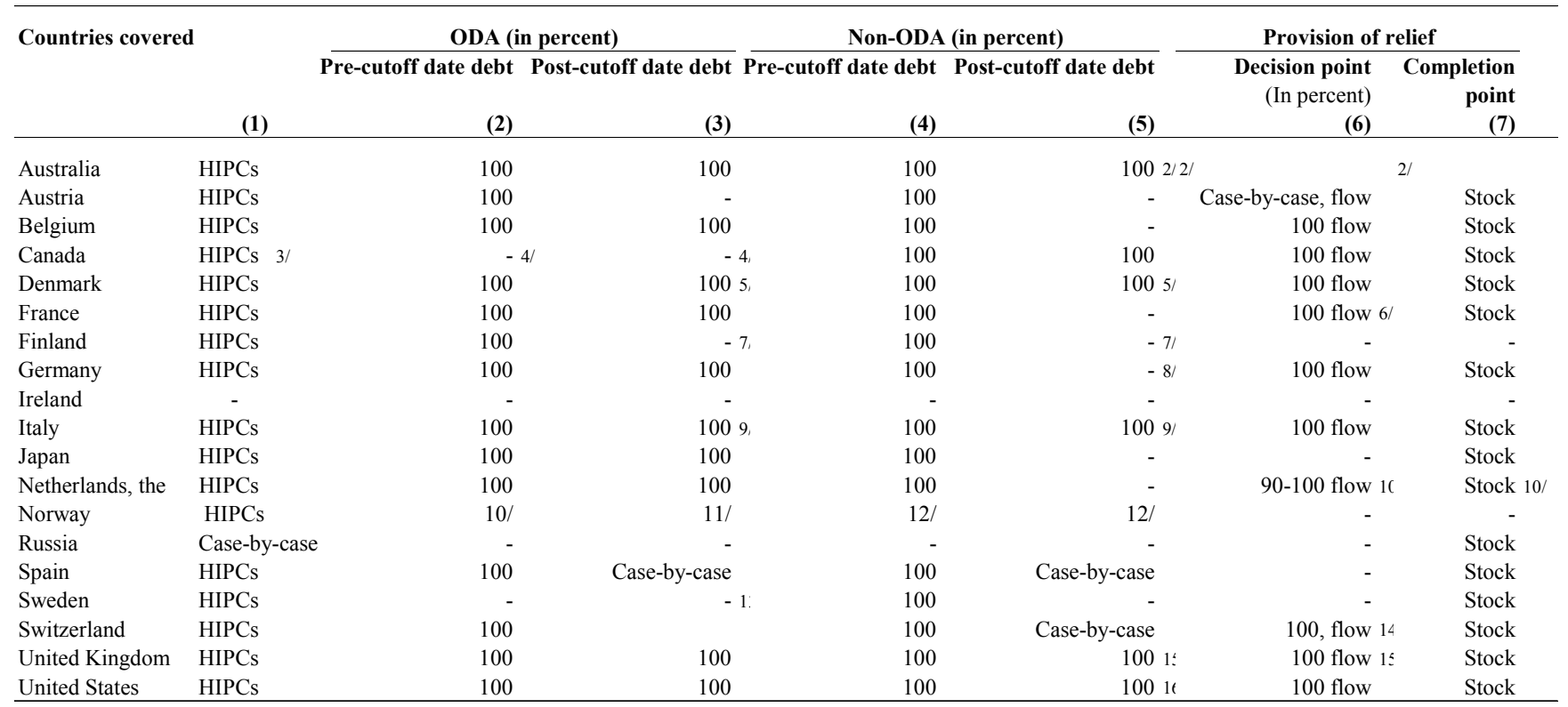

Source: Paris Club Secretariat.

1/ Columns (1) to (7) describe the additional debt relief provided following a specific methodology under bilateral initiatives and need to be read as a whole for each creditor. In column (1), "HIPCs" stands for eligible countries effectively qualifying for the HIPC process. A "100 percent" mention in the table indicates that the debt relief provided under the enhanced HIPC Initiative framework will be topped up to 100 percent through a bilateral initiative.

2/ Australia: post-cutoff date non-ODA relief to apply to debts incurred before a date to be finalized; timing details for both flow and stock relief are to be finalized.

3/ Canada: including Bangladesh. Canada has granted a moratorium of debt service as of January 2001 on all debt disbursed before end-March 1999 for 13 out of 17 HIPCs with debt service due to Canada. Eligible countries are Benin, Bolivia, Cameroon, Dem. Rep. Of Congo, Ethiopia, Ghana, Guyana, Honduras, Madagascar, Rwanda, Senegal, Tanzania, and Zambia. 100\% cancellation will be granted at completion point. As of July 2004, Canada has provided completion point stock of debt cancellation for Benin, Bolivia, Guyana, Senegal and Tanzania.

4/ 100 percent of ODA claims have already been cancelled on HIPCs, with the exception of Myanmar's debt to Canada.

5/ Denmark provides 100 percent cancellation of ODA loans and non-ODA credits contracted and disbursed before September 27, 1999.

6/ France: cancellation of 100 percent of debt service on pre-cutoff date commercial claims on the government as they fall due starting at the decision point. Once countries have reached their completion point, debt relief on ODA claims on the government will go to a special account and will be used for specific development projects.

7/ Finland: no post-COD claims

8/ Germany proposes to cancel all debts incurred before June 20, 1999 depending on a consensus within Paris Club creditors

9/ Italy: cancellation of 100 percent of all debts (pre- and post-cutoff date, ODA and non-ODA) incurred before June 20, 1999 (the Cologne Summit). At decision point, cancellation of the related amounts falling due in the interim period. At completion point, cancellation of the stock of remaining debt.

10/ The Netherlands: 100 percent ODA (pre- and post-cutoff date debt will be cancelled at decision point); for non-ODA: in some particular cases (Benin, Bolivia, Burkina Faso, Ethiopia, Ghana, Mali, Mozambique, Nicaragua, Rwanda, Tanzania, Uganda and Zambia), the Netherlands will write off 100 percent of the consolidated amounts on the flow at decision point; all other HIPCs will receive interim relief up to 90 percent reduction of the consolidated amounts. At completion point, all HIPCs will receive 100 per cent cancellation of the remaining stock of the pre-cutoff date debt.

11/ Norway has cancelled all ODA claims.

12/ Due to the current World Bank/IMF methodology for recalculating debt reduction needs at HIPC completion point, Norway has postponed the decisions on whether or not to grant $100 \%$ debt reduction until after the completion point.

13/ Sweden has no ODA claims.

14/ Switzerland: In principle 100 percent cancellation of Pre-cutoff date non-ODA debt. However, Switzerland claims the right at the decision point to forgive only 90 percent in case of major political and/or political weaknesses.

15/ United Kingdom: "beyond 100 percent" full write-off of all debts of HIPCs as of their decision points, and reimbursement at the decision point of any debt service paid before the decision point.

16/ United States: 100 percent post-cutoff date non-ODA treated on debt assumed prior to June 20, 1999 (the Cologne Summit). 


\section{Debt Management}

\section{Institutional framework}

The Malagasy debt management is shared between two units, the "Direction des Services Etrangers et de la Dette Exterieure" of the Central Bank and the "Direction de la Dette Publique" of the Ministry of Finance. The Central Bank is in charge of the database management, including the updating of all public and publicly-guaranteed external debt database, as well as the debt and debt service projections. The Ministry of Finance is responsible for the administration of all multilateral loans with exception of IMF loans, and for the direct payment of certain loans and the policy aspects of the debt strategy, such as contracting new loans and negotiating debt relief.

\section{Debt management}

In 2001, the authorities acquired UNCTAD's DMFAS (Data Management and Financial Analysis System) system and since then, the Central Bank has been migrating the debt data into the software. The lack of adequate training with few employees involved has slowed the migration process, which (including the testing of the system) is now planned to be completed in 2005. The installation of DMFAS as a network across the two units could help more efficient sharing of the data base but this may require further substantial investment. No timeline has been defined for this project.

The country's debt management capacity would benefit from more training on debt management and debt sustainability analysis. The country has been advised, among others, by UNCTAD and DRI to provide tools and training to staff to be able to manage its debt more pro-actively, but there is currently no budget to provide training for employees in charge of debt management. Graduating from HIPC, this challenge becomes even more crucial as the country will have to set up a prudent debt strategy which is fully coordinated with macroeconomic policies.

\section{Policy coordination}

The two units in charge of debt management are located in two different buildings in the city and even though there is good communication between them, there is scope for increasing efficiency through the establishment of a network for sharing the data. Costs are a constraint in moving in this direction. The disbursement and repayment units do not report systematically to the two debt units, which may make it difficult to get an accurate picture of the debt situation. The authorities are aware of this flaw and plan to rectify weaknesses. However, no timelines have been set. Although informal communication has improved, it would be useful to institutionalize a coordination committee. 